\title{
WATER RESOURCES OF MANATEE COUNTY, FLORIDA
}

U.S. GEOLOGICAL SURVEY WATER-RESOURCES INVESTIGATIONS $\mathbf{8 1 - 7 4}$

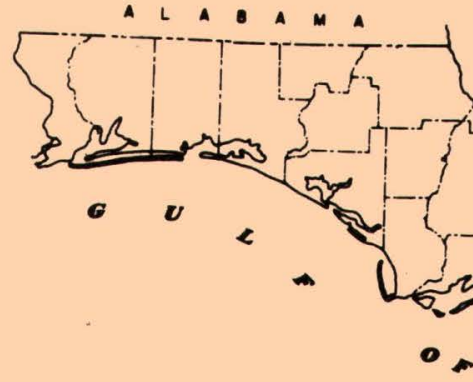

Prepared in cooperation with

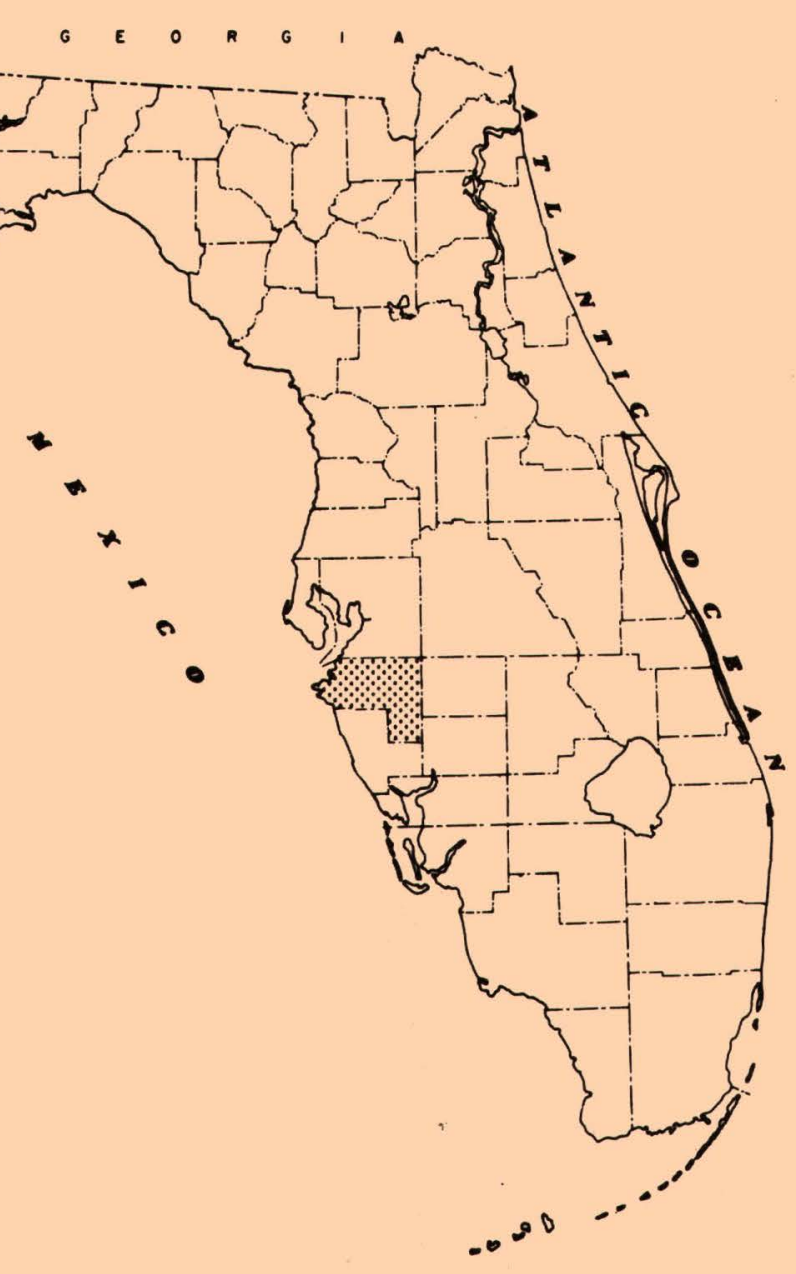
MANATEE COUNTY, FLORIDA 


\begin{tabular}{|l|l|}
\hline REPORT DOCUMENTATION & 1.-REPORT NO. \\
PAGE &
\end{tabular}

4. Title and Subtitle

WATER RESOURCES OF MANATEE COUNTY, FLORIDA

7. Author(s)

David P. Brown

9. Performing Organization Name and Address

U.S. Geological Survey, Water Resources Division

Suite 3015, Hobbs Federal Building

227 North Bronough Street

Tallahassee, Florida 32301

\section{Sponsoring Organization Name and Address}

U.S. Geological Survey, Water Resources Division

Suite 3015, Hobbs Federal Building

227 North Bronough Street

Tallahassee, Florida 32301

15. Supplementary Notes

Prepared in cooperation with Manatee County, Florida

16. Abstract (Limit: 200 words)

Rapid development of Manatee County in southwest Florida is creating water-resource problems. The report presents an evaluation of the water resources and potential effects of water-resource developments.

Most streams in the county have small drainage basins and low yields. Streamflow is variable with base flow occurring from November to May. The Manatee River and its largest tributary, the Braden River, are the principal sources of public supplies. Surface water is generally of good quality and less mineralized than ground water except in the tidally affected and coastal area.

The principal aquifers are the surficial, minor artesian, and the Floridan. The Floridan aquifer is the major source of irrigation water in the county. The minor artesian aquifer is a highly developed source of water for small rural supplies.

Withdrawals of 20 to 50 million gallons per day from the Floridan aquifer since the 1950 's have caused declines in the potentiometric surface of about 20 to 50 feet.

The quality of ground water is good except in the coastal and southern parts of the county. Water in the Floridan aquifer is generally more mineralized than the other aquifers, generally increasing in mineral content with depth and from the northeast toward the southwest.

17. Document Analysis a. Descriptors

*Surface-water resources, *Ground-water resources, *Water quality, Water utilization, Network design, Aquifers

b. Identifiers/Open-Ended Terms

Manatee County, Florida, Floridan aquifer

c. COSATI Field/Group

\begin{abstract}
18. Availability Statement
\end{abstract}
No restriction on distribution
19. Security Class (This Report) UNCLASSIFIED

20. Security Class (This Page) UNCLASSIFIED
21. No. of Pages 120

22. Price 
WATER RESOURCES OF MANATEE COUNTY, FLORIDA

By David P. Brown

U.S. GEOLOGICAL SURVEY

Water-Resources Investigations 81-74

Prepared in cooperation with

MANATEE COUNTY, FLORIDA

Tallahassee, Florida 
UNITED STATES DEPARTMENT OF THE INTERIOR

JAMES G. WATT, Secretary

GEOLOGICAL SURVEY

Dallas L. Peck, Director

For additional information write to:

U.S. Geological Survey

Suite 3015, Hobbs Federal Building

227 North Bronough Street

Tallahassee, Florida 32301 


\section{CONTENTS}

Page

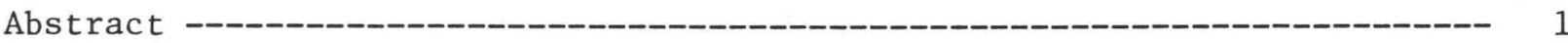

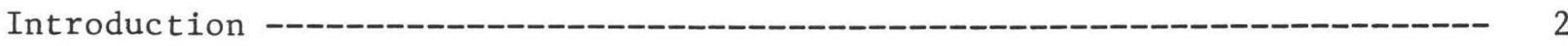

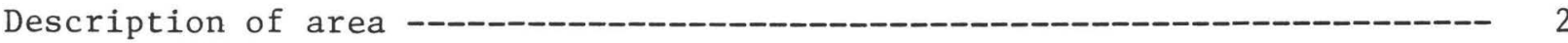

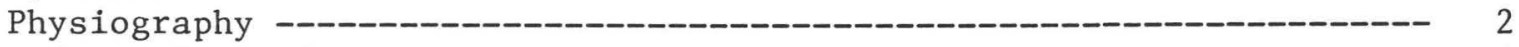

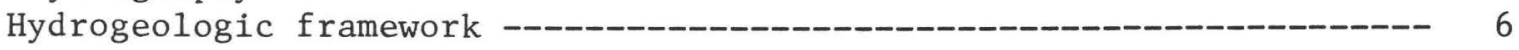

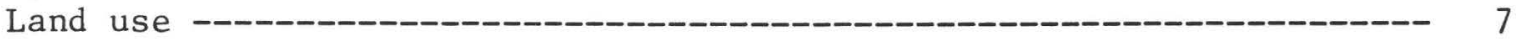

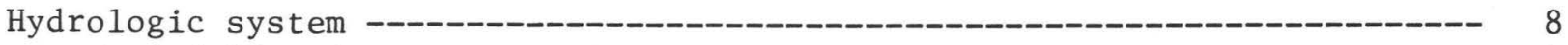

Rainfall and evapotranspiration --_-_-_-_-_-_-_-_-_-_-_-_--- 8

Surface water --_-_-_-_-_-_-_-_-_-_-_-_-_-_-_-_-_-_-_-_--- 8

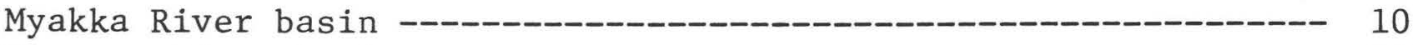

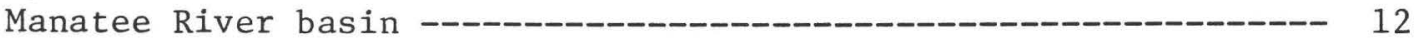

Little Manatee River basin --_-_-_-_-_-_-_-_-_-_-_------- 17

Lakes and springs --_-_-_-_-_-_-_-_-_-_-_- 17

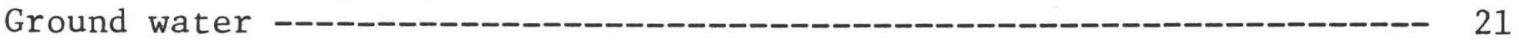

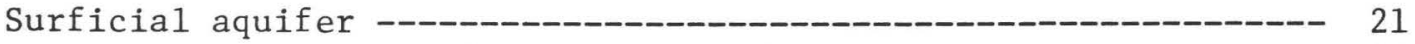

Transmissivity and storage coefficient --_--_----_-_-_----- 21

Ground-water movement, recharge, and discharge ------------ 23

Upper confining bed and minor artesian aquifer ---------------- 26

Transmissivity, storage coefficient, and leakance --------- 26

Ground-water movement, recharge, and discharge ------------ 26

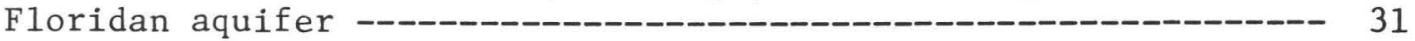

Transmissivity, storage coefficient, and leakance -------- 34

Ground-water movement, recharge, and discharge ----------- 34

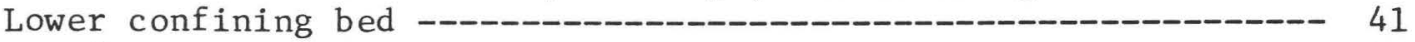

Quality of water ------ 41

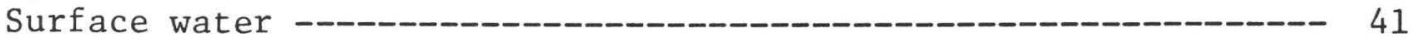

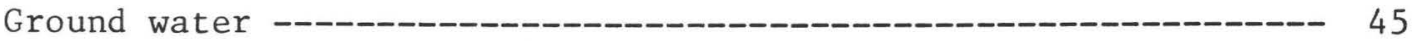

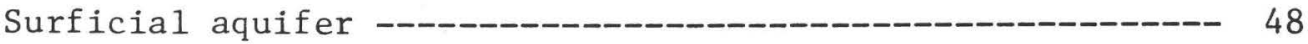

Minor artesian aquifer -

Floridan aquifer --_-- 59

Dissolved solids --_-_-_-_-_-_-_-_-_-_---_--- 59

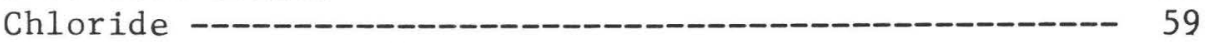

Sulfate -- 80

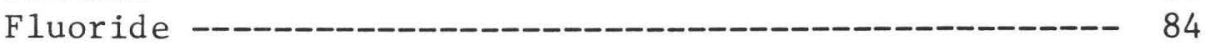

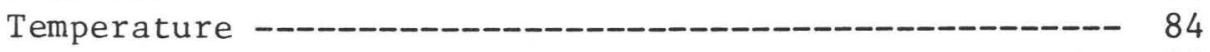

Saltwater contamination --_-_-_- 84

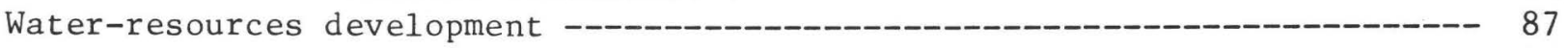

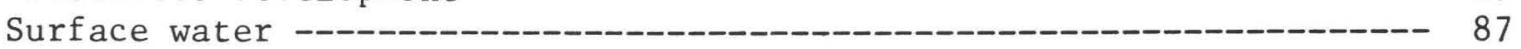

Ground water --_-_-_-_-_-_-_- 89

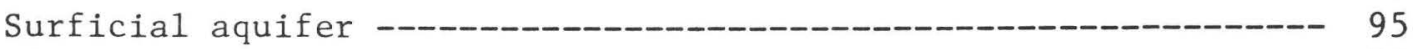

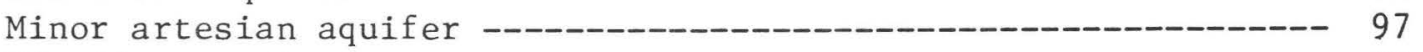

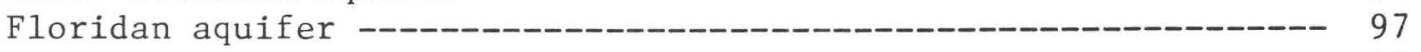

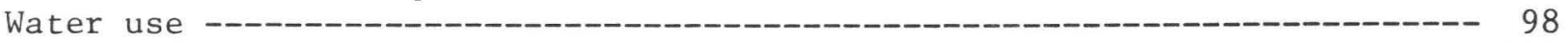

Surface water --_-_-_-_-_- 104

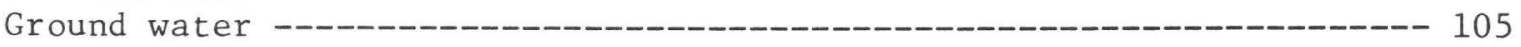

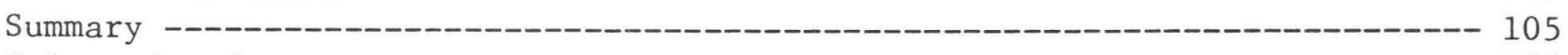

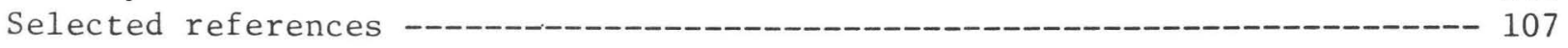




\section{ILLUSTRATIONS}

Page

Figure 1. Map showing location, topography, and physiographic units,

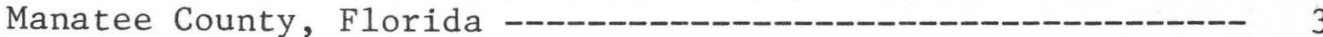

2. Map showing streams and surface-water data-collection network, Manatee County and adjacent areas --_--_---_---_------- 9

3. Graph showing streambed profile of the Myakka River ---------- 11

4. Graph showing flow-duration curves for streams in and near Manatee County --_-_-_-_-_ 13

5. Graph showing streambed profiles of streams in the Manatee River basin --_-_-_-_-_-_-_ 16

6. Geologic sections showing surficial material overlying the Hawthorn Formation -_-_-_-_-

7. Map showing generalized water table, May 1975 -_--_---_---- 24

8. Hydrographs of water levels in wells penetrating the surficial

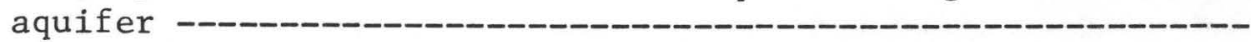

9. Map showing thickness of the upper confining bed of the Floridan aquifer system -

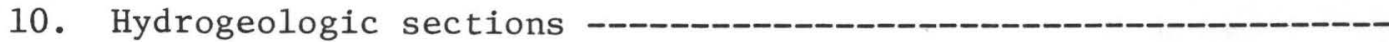

11-19. Maps showing:

11. Potentiometric surface of the minor artesian aquifer,

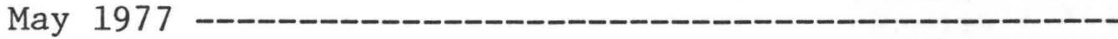

12. Potentiometric surface of the minor artesian aquifer,

13. Altitude of the top of the Floridan aquifer ----------- 32

14. Thickness of the Floridan aquifer --_-_- 33

15. Potentiometric surface of the Floridan aquifer, westcentral Florida, September 1975

16. Potentiometric surface of the Floridan aquifer, May 1975, and decline in the potentiometric surface, June 1955 to May 1975

17. Potentiometric surface of the Floridan aquifer, September 1975, and decline in the potentiometric surface, September 1954 to September 1975

18. Areas of artesian flow, May and September 1975

19. Change in potentiometric surface, May 1975 to September 1975

20. Hydrographs of water levels in selected wells penetrating the Floridan aquifer --------

21. Map showing altitude of the top of the lower confining bed of the Floridan aquifer system 
Figure 22. Graph showing seasonal variations of discharge, color, iron, $\mathrm{pH}$, and specific conductance, Manatee River near Bradenton, October 1964 to September 1965

23-29. Maps showing:

23. Quality of water from the surficial aquifer ---------

24. Concentrations of chloride, sulfate, and dissolved solids in water from the minor artesian aquifer ------ 52

25. Concentrations of dissolved solids in water from the Tampa (upper zone), Suwannee-Ocala (middle zone), and Avon Park (lower zone) Limestones -..--

26. Concentrations of chloride in water from the Tampa (upper zone), Suwannee-Ocala (middle zone), and Avon Park (lower zone) Limestones -_-_-_-_-_-_-_-_-_-_---

27. Concentrations of sulfate in water from the Tampa (upper zone), Suwannee-Ocala (middle zone), and Avon

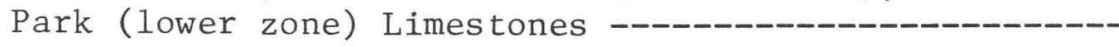

28. Concentrations of fluoride in water from the Suwannee (middle zone) and Avon Park (lower zone) Limestones --

29. Locations of potential impoundments, existing reservoirs, and stream-gaging stations, Manatee County and adjacent areas

30-35. Graphs showing:

30. Surface area and storage capacity of Lake Manatee

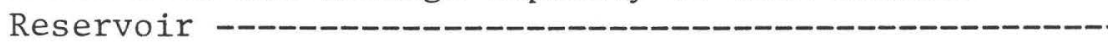

31. Draft-storage frequency relations for Lake Manatee

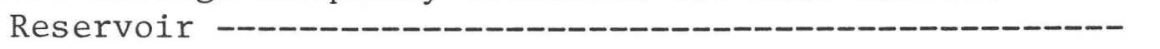

32. Draft-storage frequency relations for Myakka River near Sarasota

33. Draft-storage frequency relations for Manatee River

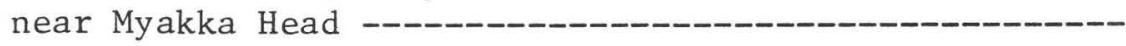

34. Draft-storage frequency relations for Little Manatee River near Wimauma --_-_-_-_-_-_-_-_-_-_-_-_-_-_-_-_--

35. Steady-state distance-drawdown and time-drawdown curves for the Floridan aquifer

36-38. Maps showing:

36. Projected potentiometric surface of the Floridan aquifer, May 2000, and decline in the potentiometric surface, May 1976 to May 2000

37. Projected potentiometric surface of the Floridan aquifer, October 2000, and decline in the potentiometric surface, November 1976 to October 2000

38. Areas where water from the Suwannee-Ocala (middle zone) and Avon Park (lower zone) Limestones exceed upper limits in concentrations of dissolved solids, chloride, and sulfate 
Table 1. Geologic formations and hydrogeologic units of Manatee County ---_-_-_- 4

2. Generalized land use, 1975, and projected land use, 2000 ----- 7

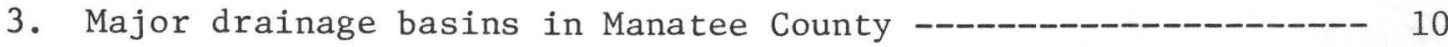

4. Summary of streamflow data from gaging stations in Manatee County and adjacent areas through September 1977 ----------- 14

5-8. Magnitude and frequency of annual low and high flows:

5. Myakka River near Sarasota -_-_-_-_- 15

6. Manatee River near Bradenton --_-_-_-_-_-_-_----- 18

7. Manatee River near Myakka Head --_-_-_-_-_-_-_----- 19

8. Little Manatee River near Wimauma --_-_-_-_-- 20

9. Range in concentration for selected water-quality parameters

for streams in Manatee County and adjacent areas ----------- 46

10. Quality of water from the surficial aquifer --------------- 50

11. Quality of water from the minor artesian aquifer ----------- 55

12. Quality of water from the Tampa Limestone (upper water-bearing

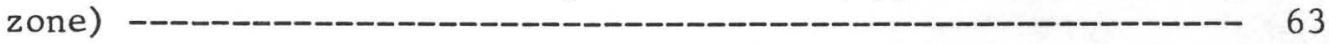

13. Quality of water from the Suwannee and Ocala Limestones

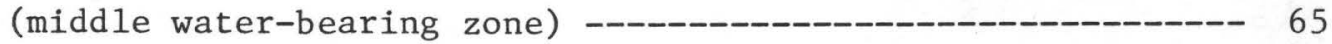

14. Quality of water from the Avon Park Limestone (lower waterbearing zone) -- 73

15. Concentrations of chloride in water from wells open to the Floridan aquifer, 1950-55 and 1975-76 --- 80

16. Potential impoundment sites in and near Manatee County ------- 95

17. Estimated hydraulic properties of aquifers and confining beds ------ 96

18. Water use, 1970-75 --_- 104

19. Water use for public supply, 1975 and 1977, and projected water use, 1980 and 1985 
Factors for converting inch-pound units to International System (SI) units and abbreviation of units

Multiply inch-pound unit

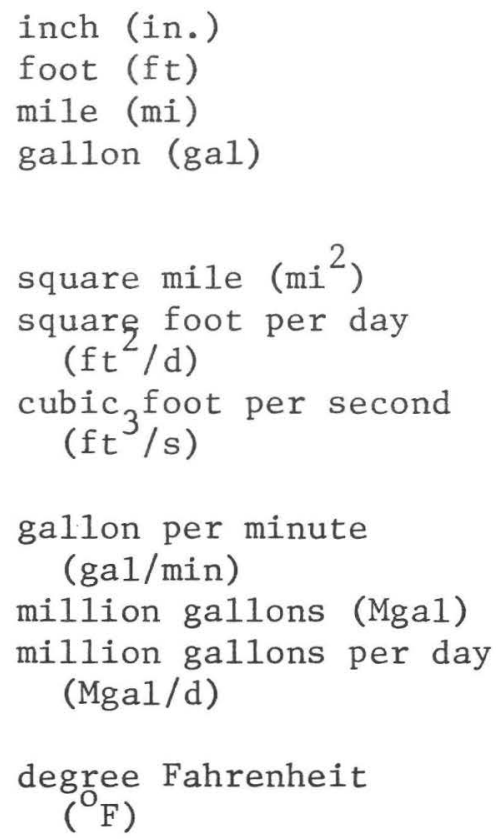

By

$$
25.4
$$$$
0.3048
$$$$
1.609
$$$$
3.785
$$$$
0.003785
$$

0.09290

0.02832

0.6309

3,785

0.04381

$\left({ }^{\mathrm{O}} \mathrm{F}-32\right) / 1.8$
To obtain metric (SI) unit

$$
\begin{aligned}
& \text { millimeter }(\mathrm{mm}) \\
& \text { meter }(\mathrm{m}) \\
& \text { kilometer }(\mathrm{km}) \\
& \text { liter }(\mathrm{L}) \\
& \text { cubic meter }\left(\mathrm{m}^{3}\right)
\end{aligned}
$$

$$
\text { square kilometer }\left(\mathrm{km}^{2}\right)
$$$$
\text { square meter per day }
$$$$
\left(\mathrm{m}^{2} / \mathrm{d}\right)
$$

cubic meter per second $\left(\mathrm{m}^{3} / \mathrm{s}\right)$

liter per second (L/s).

cubic meter $\left(\mathrm{m}^{3}\right)$ cubic meter per second $\left(\mathrm{m}^{3} / \mathrm{s}\right)$

degree Celsius $\left({ }^{\circ} \mathrm{C}\right)$

National Geodetic Vertical Datum of 1929 (NGVD of 1929).--A geodetic datum derived from a general adjustment of the first-order level nets of both the United States and Canada, formerly called mean sea level. In this report, NGVD of 1929 is referred to as sea level. 

By David P. Brown

\author{
ABSTRACT
}

Rapid development of Manatee County in southwest Florida and changes from an agricultural-retirement area to an urban-industrial area are creating waterresource problems. Evaluation of the water resources and potential effects of water-resource developments on the hydrologic environment can define and document water-quality and water-resource problems and water-management and regulatory needs.

Most streams in the county have small drainage basins, short channel lengths, and have low discharges. Streamflow is highly variable with base flow or zero flow occurring in the upper reaches of streams from November to May. The average discharge for 26 years of record of Manatee River near Bradenton is 109 cubic feet per second. Fifty percent of the time, flow near Bradenton may be expected to equal or exceed 24 cubic feet per second.

Surface water is generally less mineralized than ground water except in the tidally affected and coastal areas. Surface water generally is of good chemical quality and suitable for most purposes.

The Manatee River at Lake Manatee Reservoir and its principal tributary, the Braden River at Ward Lake, are sources for public water supplies. In 1977, average daily pumpage at Lake Manatee Reservoir and Ward Lake was 19.1 and 4.0 million gallons per day, respectively.

The principal aquifers in the county are the surficial aquifer, minor artesian aquifer, and the Floridan aquifer. The surficial aquifer is virtually undeveloped as a source of water; the minor artesian aquifer is a highly deyeloped source of water for rural domestic and small public supplies. The Floridan aquifer is the major source of water in the county; the water is primarily used for irrigation. The Floridan aquifer system includes the upper confining beds, the Floridan aquifer, and the lower confining bed. Within the upper confining beds there are permeable zones that form the minor artesian aquifer.

Large withdrawals of water, 20 to 50 million gallons per day, from the Floridan aquifer since the 1950's have caused declines in the potentiometric surface of about 20 feet during periods of minimum pumpage and about 50 feet during periods of maximum pumpage. Seasonal fluctuations have increased from about 10 feet in $1954-55$ to 30 feet in 1975 .

The quality of ground water is good except in the western (coasta1) and southern parts of the county where saltwater intrusion or incomplete flushing of residual seawater has occurred. Water in the Floridan aquifer is generally more mineralized than water from the surficial and minor artesian aquifers. The mineral content of water from the Floridan aquifer generally increases 
with depth and from the northeast towards the west and south. Concentrations of chloride greater than 250 milligrams per liter occur in aquifers of the coastal part of the county. Concentrations of sulfate greater than 250 milligrams per liter occur in aquifers of the western and southern parts of the county.

\section{INTRODUCTION}

Manatee County, on the west-central coast of Florida, abuts Tampa Bay about 30 miles south of Tampa. Rapid development of the western part of the county and change from an agricultural-retirement area to an urban-industrial area are creating water-resource problems. A need exists for hydrologic information and evaluation of the effects of proposed water-resources developments on the county's hydrologic environment. Recognizing the need, the U.S. Geological Survey, in cooperation with Manatee County, undertook a study to evaluate the water resources of Manatee County. These activities will aid public officials in management of the county's water resources.

The purpose of this report is (1) to describe the geology, hydrology, and quality of water of Manatee County and (2) to evaluate the availability of surface and ground water for development. The report provides Manatee County, the Southwest Florida Water Management District, and the Florida Department of Natural Resources with a data base and an evaluation of the water resources of the area so that water-quality and water-resource problems and water-management and regulatory needs can be adequately defined and documented.

\section{DESCRIPTION OF AREA}

Manatee County is bounded by Hillsborough County to the north, DeSoto and Hardee Counties to the east, Sarasota County to the south, and Tampa Bay and the Gulf of Mexico to the west (fig. 1). The county contains about $739 \mathrm{mi}^{2}$ of land area and $46 \mathrm{mi}^{2}$ of inland surface water. The climate is subtropical, characterized by warm summers and mild winters. The mean annual temperature is about $72^{\circ} \mathrm{F}$. Mean monthly temperatures range from about $60^{\circ}$ to $80^{\circ} \mathrm{F}$.

\section{Physiography}

Manatee County lies within three physiographic units as described by White (1970). These units include the Gulf Coastal Lowlands, the DeSoto Plain, and the Polk Upland (fig. 1). Topography of these areas is largely controlled by a series of marine terraces that formed during Pleistocene time when the sea stood above its present level (Peek, 1958a). Altitudes of land surface range from sea leve1 along the coast to about 170 feet above sea level in the northeast.

The Pamlico terrace, generally less than 20 feet above sea leve1, and the Talbot terrace, about 40 feet above sea level, form the relatively flat, poorly drained Gulf Coastal Lowlands. The Penholoway terrace, about 60 to 70 feet 


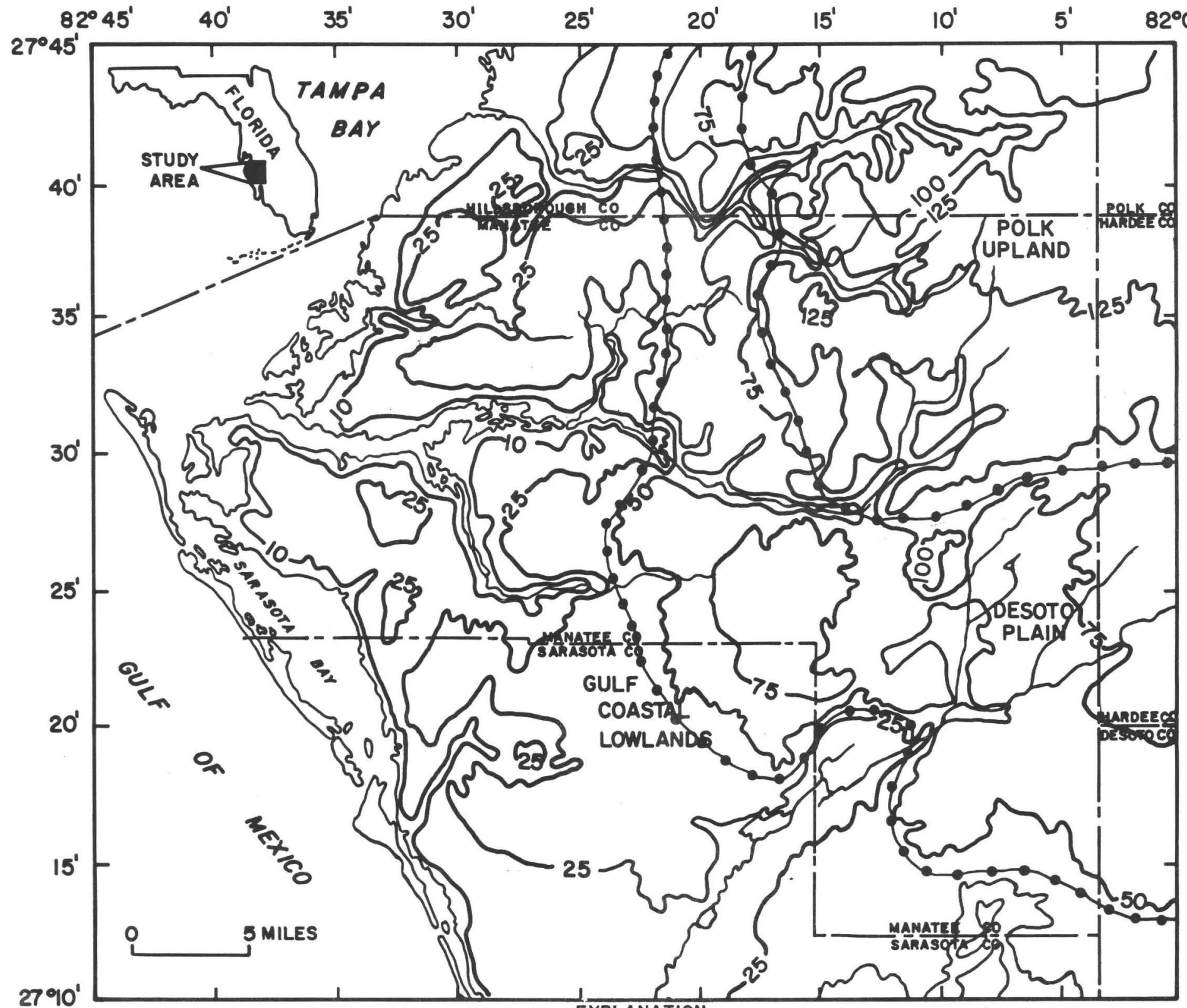

EXPLANATION

-25-TOPOGRAPHIC CONTOUR - - SHOWS ALTITUDE OF LAND SURFACE. CONTOUR INTERVAL 25 FEET. SUPPLEMENTAL IO-FOOT CONTOUR LINE. DATUM IS NATIONAL GEODETIC VERTICAL DATUM OF I 929 $\multimap \longrightarrow$ PHYSYOGRAPHIC BOUNDARY

Figure 1.--Location, topography, and physiographic units, Manatee County, Florida. 
Table 1.--Geologic formations and hydrogeologic units of Manatee County

[Modified from Peek, 1958, p. 15]

\begin{tabular}{|c|c|c|c|c|c|}
\hline System & Series & Formation & Characteristics & $\begin{array}{c}\text { Thickness } \\
\text { (feet) }\end{array}$ & $\begin{array}{c}\text { Hydrogeologic } \\
\text { unit }\end{array}$ \\
\hline \multirow[t]{2}{*}{$\begin{array}{l}\text { Quater- } \\
\text { nary }\end{array}$} & Holocene & $\begin{array}{r}\text { Surficial } \\
\text { deposits }\end{array}$ & Soil, muck, alluvium, sand. & $0-20$ & \multirow{2}{*}{$\begin{array}{l}\text { Surficial } \\
\text { aquifer }\end{array}$} \\
\hline & $\begin{array}{l}\text { Pleisto- } \\
\text { cene }\end{array}$ & $\begin{array}{l}\text { Pamlico Sand } \\
\text { O1der terrace } \\
\text { deposits }\end{array}$ & $\begin{array}{l}\text { Sand, shells, limestone. } \\
\text { Sand. }\end{array}$ & $\begin{array}{l}0-20 \\
0-60\end{array}$ & \\
\hline \multirow[t]{2}{*}{ Tertiary } & P1iocene & $\begin{array}{l}\text { Caloosahatchee } \\
\text { ? Mar1 } \\
\text { Bone Valley } \\
\text { Formation }\end{array}$ & $\begin{array}{l}\text { Mar1, sand and gravel of quartz and phos- } \\
\text { phate, shells, bone fragments. } \\
\text { Sand and gravel of quartz and phosphate; } \\
\text { clay, bone fragments. }\end{array}$ & $\begin{array}{l}0-10 \\
0-30 ?\end{array}$ & \multirow[b]{2}{*}{$\begin{array}{l}\text { Upper confin- } \\
\text { ing beds and } \\
\text { minor arte- } \\
\text { sian aquifer }\end{array}$} \\
\hline & Miocene & $\begin{array}{l}\text { Hawthorn } \\
\text { Formation }\end{array}$ & $\begin{array}{l}\text { Clay and marl, gray, greenish and bluish } \\
\text { gray, sandy, phosphatic, calcareous, in- } \\
\text { terbedded with sandy limestone, silt, } \\
\text { sand, and shells. The sand, shell, and } \\
\text { limestone beds are the source of small } \\
\text { water supplies. The water in the } \\
\text { Hawthorn Formation is under artesian } \\
\text { pressure and is generally less mineral- } \\
\text { ized than the water in the Tampa and } \\
\text { older formations. }\end{array}$ & $150-360$ & \\
\hline
\end{tabular}




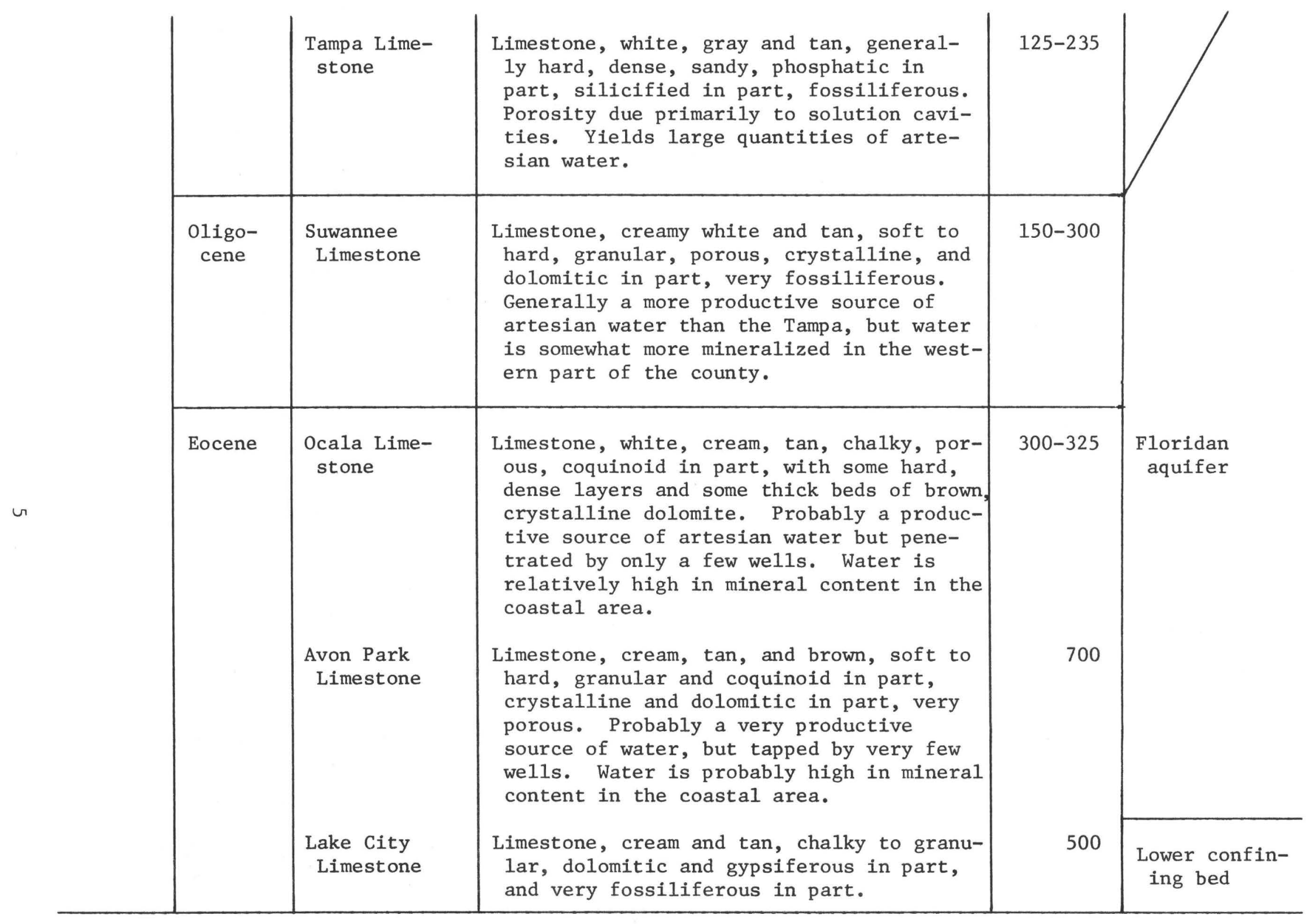


above sea level, and the Wicomaco terrace, about 90 to 100 feet above sea level, comprise the DeSoto Plain. The highest and oldest surface is the Sunderland terrace that formed when the sea was about 170 feet above its present level. The Sunderland terrace forms the Polk Upland physiographic unit. The terraces have been modified by stream dissection, but there are large areas of relatively flat surfaces where drainage is poorly developed.

Surface drainage of the county is principally through the Manatee, Little Manatee, and Myakka Rivers and their tributaries. Much of the coastal area is drained by small streams that flow directly into the Gulf of Mexico. Large portions of the county, generally associated with the relatively flat terraces, are poorly drained and contain numerous small, shallow lakes and swamps. A network of canals has been dug throughout the county to augment natural drainage.

\section{Hydrogeologic Framework}

Knowledge of the hydrogeology of an area is essential in evaluating its water resources. Lithology and structure affect and control the occurrence, movement, and quality of ground water and surface water. A general description of the geologic framework is discussed below. Detailed discussions related to aquifers and confining-bed characteristics are contained in the ground-water section of this report.

Manatee County is underlain by a thick sequence of sedimentary rocks consisting of limestones and dolomites overlain by sands, clays, and marls interbedded with limestone. Table 1 shows the age, thickness, and lithology of the stratigraphic units penetrated by water wells. The units range in age from Eocene to Holocene and include, in ascending order, the following: the Lake City Limestone, Avon Park Limestone, Ocala Limestone, Suwannee Limestone, Tampa Limestone, Hawthorn Formation, and surficial deposits consisting of the Bone Valley Formation, Caloosahatchee (?) Marl, Pleistocene terrace deposits, and recent sediments. The surficial deposits and the upper part of the Hawthorn Formation are exposed in outcrops. Subsurface stratigraphic units are described on the basis of rock cuttings, geophysical logs, geologic logs, and drillers' logs.

The principal aquifers are (1) the surficial aquifer, (2) the minor artesian aquifer, and (3) the Floridan aquifer. The surficial aquifer consists of Pliocene and Pleistocene surficial deposits. Water in these deposits occurs in primary openings, such as spaces between grains. The minor artesian aquifer consists of Hawthorn Formation limestone and dolomite beds, mar1, sand, and clay, while the Floridan aquifer consists of beds of limestone and dolomite. Water in these two aquifers occurs and moves principally in secondary openings, such as joints along bedding planes and pores that commonly have been enlarged from solution by water. 
In 1975, major land uses in Manatee County were: (1) rangeland, about 235,000 acres; (2) agricultural land, about 158,000 acres; and (3) urban land, about 38,000 acres (table 2). Principal types of agricultural land were cropland and pasture, 136,000 acres, and orchards and groves, 22,000 acres. Residential land, about 19,000 acres or 3.9 percent of the county, constituted half the urban and built-up land use.

Projected major land uses in the year 2000 remain rangeland, agricultural land, and urban or built-up land. Rangeland and agricultural land will comprise 234,000 acres and 146,000 acres, respectively, a slight decrease from that of 1975. Urban or built-up land will comprise 53,500 acres, an increase of about 30 percent from 1975.

Strip mines, quarries, and gravel pits represent the greatest projected change in acreage from 1975 to 2000. This reflects projected phosphate mining in eastern Manatee County. Mining is projected to utilize 2.5 percent of the land of the county by 1985 then decrease to about 1.8 percent by 2000 . By 2035, most mining activity should be complete; representing less than 0.1 percent of land use in the county.

Table 2.--Generalized 1and use, 1975, and projected land use, 2000

[Modified from Texas Instruments Incorporated, 1978]

\begin{tabular}{|c|c|c|c|c|c|}
\hline \multirow[b]{2}{*}{ Land use } & \multicolumn{2}{|c|}{1975} & \multicolumn{2}{|c|}{2000} & \multirow{2}{*}{$\begin{array}{l}\text { Percent } \\
\text { change } \\
1975-2000\end{array}$} \\
\hline & Acres & $\begin{array}{l}\text { Percentage } \\
\text { of study } \\
\text { area }\end{array}$ & Acres & $\begin{array}{l}\text { Percentage } \\
\text { of study } \\
\text { area }\end{array}$ & \\
\hline Rangeland & 235,329 & 47.40 & 234,130 & 47.16 & -0.5 \\
\hline $\begin{array}{l}\text { Agricultural land } \\
\text { Cropland and pasture } \\
\text { Orchards and groves } \\
\text { Other }\end{array}$ & $\begin{array}{r}158,783 \\
136,427 \\
22,356 \\
-\end{array}$ & $\begin{array}{r}32.00 \\
27.48 \\
4.52 \\
---\end{array}$ & $\begin{array}{c}146,331 \\
127,330 \\
19,001 \\
---\end{array}$ & $\begin{array}{r}29.48 \\
25.65 \\
3.83 \\
---\end{array}$ & $\begin{array}{r}-8.5 \\
-7.1 \\
-18.0 \\
---\end{array}$ \\
\hline Urban or built up & 38,152 & 7.67 & 53,555 & 10.78 & 28.8 \\
\hline Forest land & 8,992 & 1.81 & 8,868 & 1.79 & -1.1 \\
\hline Water & 14,572 & 2.94 & 14,572 & 2.94 & 0 \\
\hline Wetlands & 27,151 & 5.47 & 26,266 & 5.29 & -3.3 \\
\hline $\begin{array}{l}\text { Barren land } \\
\text { Strip mines, quarries, } \\
\text { and gravel pits } \\
\text { Other }\end{array}$ & $\begin{array}{r}200 \\
13,276\end{array}$ & $\begin{array}{r}.04 \\
2.67\end{array}$ & $\begin{array}{l}8,702 \\
4,031\end{array}$ & $\begin{array}{r}1.75 \\
.81\end{array}$ & $\begin{array}{r}4,275 \\
-229.6\end{array}$ \\
\hline Total & 496,455 & 100.0 & 496,455 & 100.0 & \\
\hline
\end{tabular}


The source of freshwater in Manatee County is from rainfall in the county or in adjacent areas. Part of the rainfall collects in topographic depressions such as lakes, swamps, and marshes, or enters stream channels and flows out of the county. Some rainfall infiltrates into the soil and shallow aquifers, eventually returning to the surface as seepage and spring flow, or infiltrates into deep aquifers where it may remain in storage for thousands of years or until pumped. Most rainfall, however, returns to the atmosphere by evapotranspiration.

\section{$\underline{\text { Rainfall and Evapotranspiration }}$}

The average annual rainfall in Manatee County is about 55 inches. Annual rainfall at Bradenton, near the coast, averaged 56.1 inches from 1956 to 1976; normal annual rainfall (1941-70) is 56.4 inches. From 1956 to 1976, average annual rainfall at Fort Green, in northeastern Manatee County, was 53.6 inches. From 1960 to 1976, rainfall was generally below normal; the cumulative departure from average annual rainfall (1956-76) was -44.6 inches at Bradenton and -33.8 inches at Fort Green.

The rainy season extends from June through September when about 60 percent of the yearly rainfall occurs. Average rainfall during this period ranges from about 6 to 9 inches per month. The rains are generally associated with convective thunderstorms. From June to November, the county may be subjected to tropical storms and hurricanes; associated with these storms is heavy rainfall that may be as great as 15 inches or more.

The dry season is from October to May. From October to May, rainfall ranges from about 1.5 to 3 inches per month in Manatee County. Often from March to May, there is little or no measurable rainfall for 60 days or more.

Evapotranspiration in Manatee County is estimated to be about 39 inches per year (Cherry and others, 1970). About 60 percent occurs from May to October (Southwest Florida Water Management District, 1978). Average annual lake evaporation is estimated to be about 52 inches per year (Joyner and Sutcliffe, 1976).

\section{Surface Water}

The major drainage basins in Manatee County are the Myakka River, Manatee River, and Little Manatee River (table 3 and fig. 2). A small part of eastern Manatee County is in the Peace River basin. Small streams and canals occur along the coast between the Myakka and Manatee Rivers and along Tampa Bay north of the Manatee River. These streams and canals, such as Frog Creek and Palma Sola Creek, rise within several miles of the coast and flow into bays and estuaries. Each is tidal throughout much of its length. 

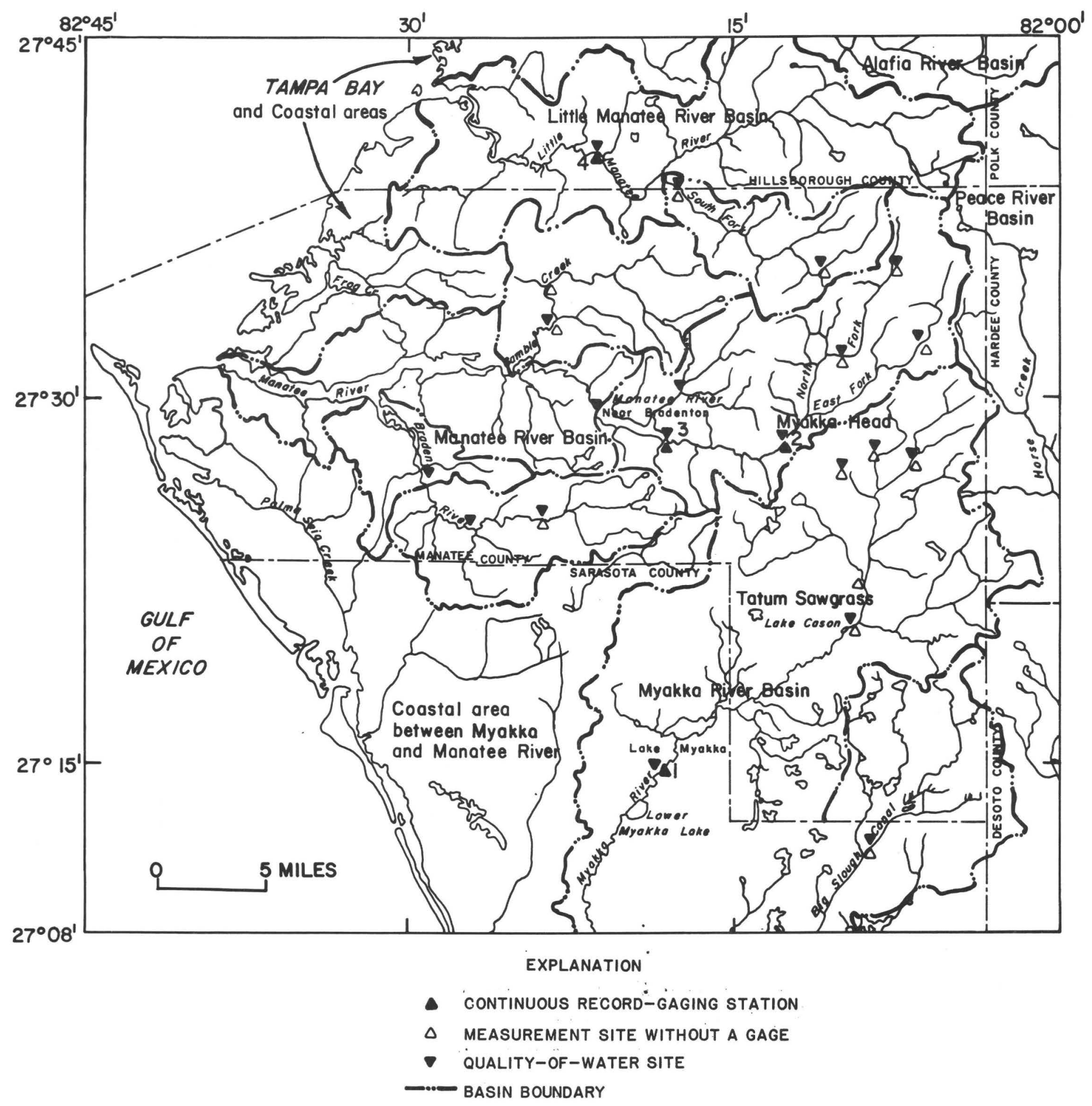

NUMBERS REFERENCE SITES LISTED IN TABLE 4

Figure 2.--Streams and surface-water data-collection network, Manatee County and adjacent areas. 
Table 3.--Major drainage basins in Manatee County

\begin{tabular}{l|r|c}
\hline \multirow{2}{*}{\multicolumn{1}{c|}{ Drainage basin }} & \multicolumn{2}{|c}{ Drainage area } \\
\cline { 2 - 3 } & $\begin{array}{c}\text { Tota1 } \\
\left(\mathrm{mi}^{2}\right)\end{array}$ & $\begin{array}{c}\text { Manatee } \\
\text { County } \\
\left(\mathrm{mi}^{2}\right)\end{array}$ \\
\hline Peace River & 2,403 & 19 \\
Myakka River & 550 & 229 \\
Coastal area between Myakka & & \\
and Manatee Rivers & 425 & 45 \\
Manatee River & 357 & 345 \\
Little Manatee River & 211 & 72 \\
Tampa Bay and coastal areas & 877 & 42 \\
\hline
\end{tabular}

Myakka River Basin

Most of the Myakka River basin is in the Gulf Coastal Lowlands and the DeSoto Plain physiographic units. A small area in the headwaters is in the Polk Upland unit. The maximum elevation, 116 feet, is in the northeastern part of the basin where terraces have been eroded into rolling hills. The southwestern part of the basin is less than 20 feet above sea level and has little local relief.

The larger streams and canals that make up the drainage system are shown in figure 2. Large swampy areas border many channels. In the broad flatlands, most natural drainageways are shallow sloughs that range in width from a few feet to more than 1 mile. Only the Myakka River channel is well defined and naturally entrenched throughout. Many sloughs and swampy areas have been drained by ditches and canals. Agricultural areas in the upper Big Slough and recently developed residential areas have undergone extensive drainage changes.

Below an altitude of about 60 feet, hundreds of shallow depressions dot the landscape. Few depressions are perennial ponds or lakes, but all, unless drained by canals, hold water during wet weather.

The Myakka River rises in northeastern Manatee County and flows southyard to the Gulf of Mexico. The river is 69 miles 1 ong and drains about $229 \mathrm{mi}^{2}$ in Manatee County. In the upper part, the channel has a fairly steep gradient (about $5 \mathrm{ft} / \mathrm{mi}$ ); in the lower parts, the channel gradient is generally less than $1 \mathrm{ft} / \mathrm{mi}$ (fig. 3).

Lake Myakka and Lower Myakka Lake, located in Sarasota County, are the largest lakes in the basin and have a combined surface area of about 1,380 acres. The Tatum Sawgrass, a 4,300-acre marsh 4 miles northeast of Lake Myakka, ranges in altitude from about 15 to 20 feet and is several feet above the normal lake level of Lake Myakka. This marsh is flooded only following exceptionally heavy rainfall. 


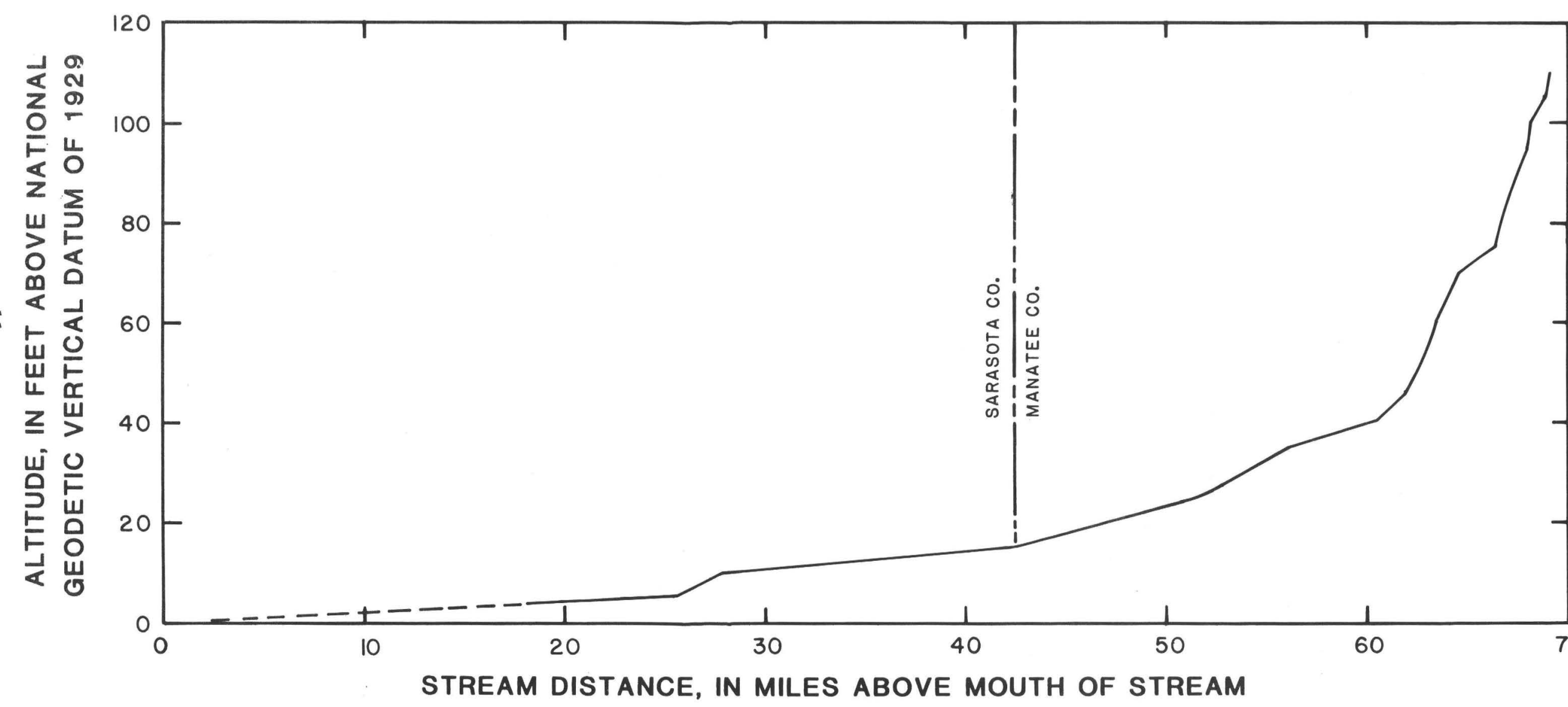

Figure 3.--Streambed profile of the Myakka River. 
From 1937 to 1977, the discharge of the Myakka River near Sarasota has been gaged at a site between Lake Myakka and Lower Myakka Lake, aboyt 36 miles upstream from its mouth. The average discharge at the site (229 $\mathrm{mi}^{2}$ drainage area) is $253 \mathrm{ft}^{3} / \mathrm{s}$ or about 15 inches of runoff per year (table 4).

The flow-duration curve for the Myakka River near Sarasota is shown in figure 4. The curve shows the percent of time that specific discharges were equaled or exceeded during the period of record. ${ }_{3}$ For example, 50 percent of the time the discharge equaled or exceeded $500 \mathrm{ft}^{3} / \mathrm{s}$. The steepness of the curve indicates a high variability in streamflow. The general flattening of the curve at its upper end indicates storage and gradual release of water from lakes and swamps during periods of heavy precipitation.

The magnitude and frequency of annual low and high flows for Myakka River near Sarasota are presented in table 5. A statistical analysis of the 41 years of continuous data indicate that there is no flow in the stream for extended periods of time; there is no flow for 15 consecutive days at intervals averaging 2 years, and for 90 days at intervals averaging 10 years.

Big Slough Canal and Mud Lake Slough drain about $48 \mathrm{mi}^{2}$ of southeastern Manatee County and eastern Sarasota County. The canals drain flat, swampy lowlands that are generally less than 50 feet above sea level. The sloughs have been deepened mainly to drain agricultural lands, and this deepening has probably increased low flows (Flippo and Joyner, 1968). The estimated 7-gay 2-year annual low flow of Big Slough near Myakka City drainage area $\left(36.5 \mathrm{mi}^{2}\right)$ is about $0.1 \mathrm{ft} / \mathrm{s}$ and the 7-day 10-year annual low flow is zero (Flippo and Joyner, 1968).

\section{Manatee River Basin}

The Manztee River and its principal triputary, the Braden River, drain about $345 \mathrm{mi}^{2}$ in Manatee County, about $10 \mathrm{mi}^{2}$ in Sarasota County, and about $2 \mathrm{mi}^{2}$ in southwest Hillsborough County. Most of the basin is in the Gulf Coastal Lowlands. A small area in the headwaters is in the Polk Upland. The eastern part of the basin consists of relatively flat terraces that are poorly drained and contain numerous, small, shallow lakes, ponds, and swamps.

The Manatee River rises in northeastern Manatee County and flows westward to the Gulf of Mexico. The river is about 53 miles long. At its source, the channel is about 130 feet above sea level. In the upper part, the channel has a fairly steep gradient $(5 \mathrm{ft} / \mathrm{mi})$; in the lower part, it is affected by tides for about 20 miles upstream from the mouth (fig. 5).

Discharge of the Manatee River was gaged from 1939 to 1965 near Bradenton and from 1966 to 1977 near Myakka Head (table 4 and fig. 2). The average discharge (26 years) near Bradenton was $109 \mathrm{ft}^{3} / \mathrm{s}$, or 17.0 inches of rupoff per year. The average discharge (11 years) near Myakka Head was $63.6 \mathrm{ft} / \mathrm{s}$, or 13.2 inches per year.

The flow-duration curves for the Manatee River near Bradenton and near Myakka Head are shown in figure 4. Ninety percent of the time, flow near Brazdenton exceeded $9 \mathrm{ft} / \mathrm{s}$, and 50 percent $\mathrm{gf}_{\mathrm{f}}$ the time, it exceeded about 100 $\mathrm{ft}_{3} / \mathrm{s}$. Flow near Myakka Head exceeded $6 \mathrm{ft}^{3} / \mathrm{s} 90$ percent of the time and 70 $\mathrm{ft}^{3} / \mathrm{s} 50$ percent of the time. 


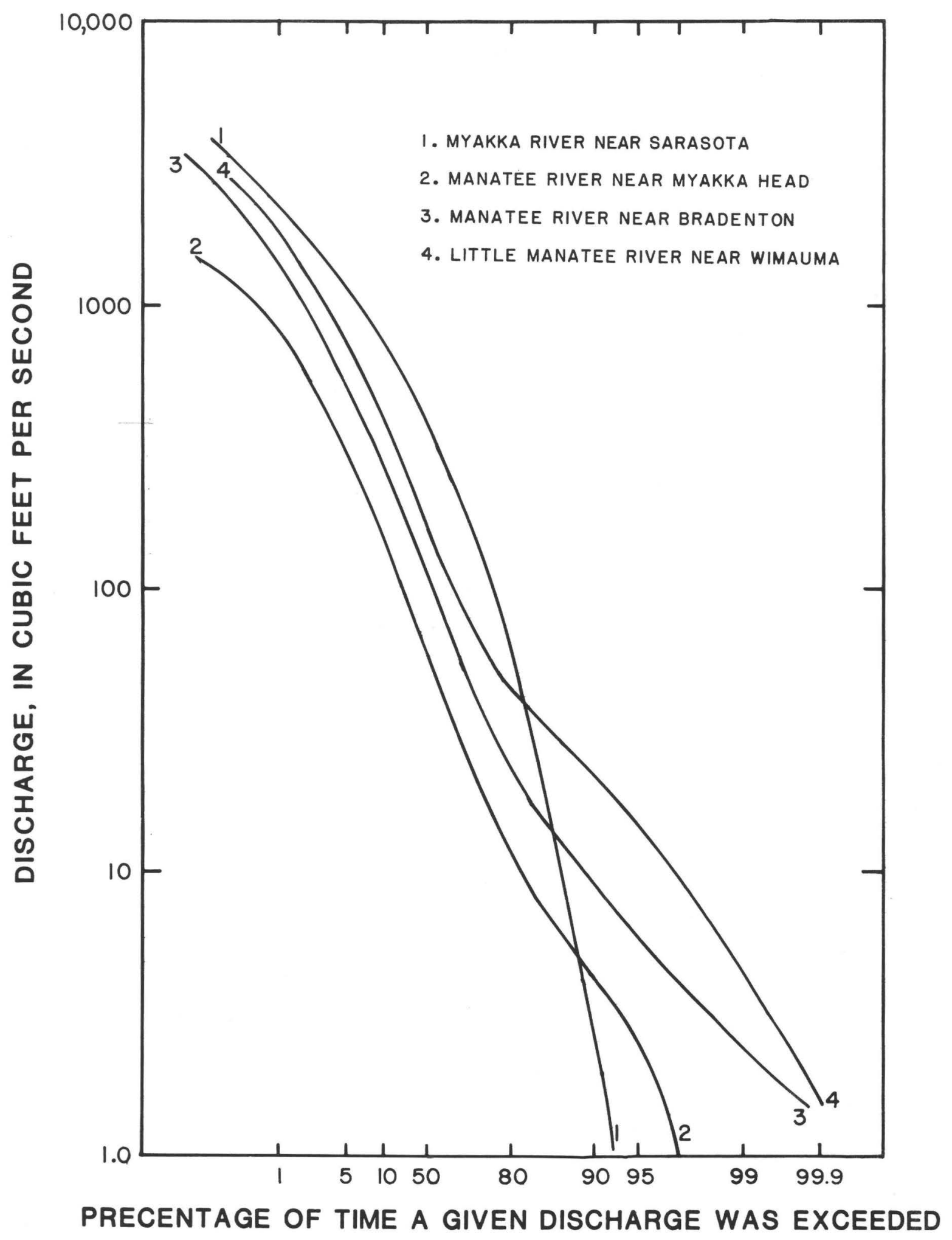

Figure 4.--Flow-duration curves for streams in and near Manatee County. 
Table 4.--Summary of streamflow data from gaging stations in Manatee County and adjacent areas through September 1977

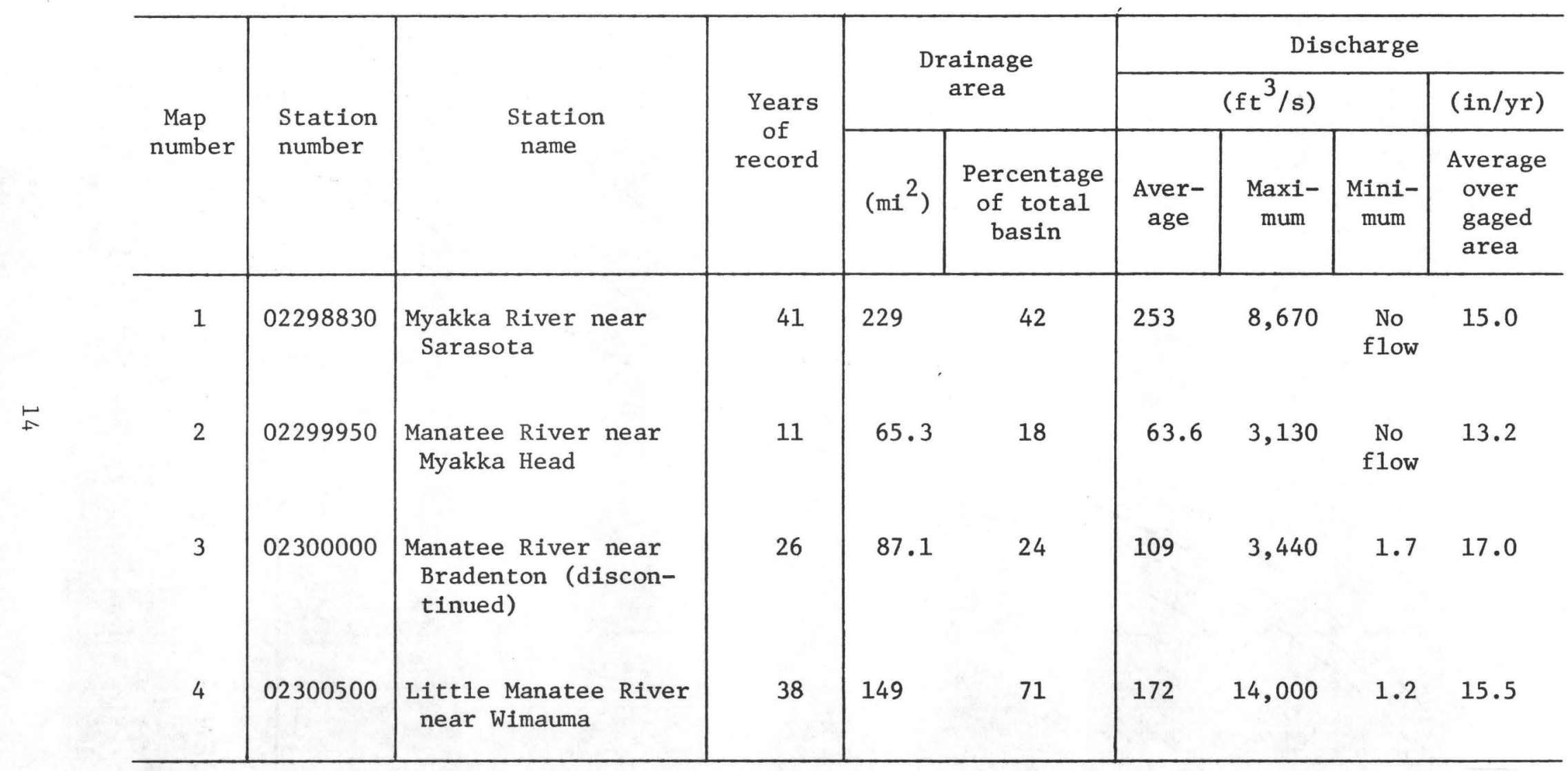


Table 5.--Magnitude and frequency of annual low and high flows, Myakka River near Sarasota

\begin{tabular}{c|c|c|c|c|c|c}
\hline \multirow{2}{*}{$\begin{array}{c}\text { Period } \\
\text { consecutive } \\
\text { days) }\end{array}$} & \multicolumn{6}{c}{$\begin{array}{c}\text { Lowest average flow, in cubic feet per second, } \\
\text { for indicated recurrence intervals, in years }\end{array}$} \\
\cline { 2 - 7 } & 2 & 5 & 10 & 20 & 50 & 100 \\
\hline 7 & 0 & 0 & 0 & 0 & 0 & 0 \\
15 & 0 & 0 & 0 & 0 & 0 & 0 \\
30 & .1 & 0 & 0 & 0 & 0 & 0 \\
60 & 1.7 & 0 & 0 & 0 & 0 & 0 \\
90 & 5.5 & .1 & 0 & 0 & 0 & 0 \\
120 & 11 & 1.1 & .1 & 0 & 0 & 0 \\
183 & 30 & 6.2 & 2.5 & 1.1 & .4 & .2 \\
365 & 230 & 150 & 120 & 100 & 81 & 70 \\
\hline
\end{tabular}

\begin{tabular}{c|r|r|r|r|rrr}
\hline \multirow{2}{*}{$\begin{array}{c}\text { Period } \\
\text { consecutive } \\
\text { days) }\end{array}$} & \multicolumn{6}{|c}{$\begin{array}{c}\text { Highest average flow, in cubic feet per second, } \\
\text { for indicated recurrence intervals, in years }\end{array}$} \\
\cline { 2 - 7 } & \multicolumn{1}{|c|}{2} & 5 & 10 & 25 & 50 & 100 \\
\hline 7 & 1,800 & 2,900 & 3,800 & 5,100 & 6,300 & 7,600 \\
15 & 1,400 & 2,100 & 2,600 & 3,400 & 4,100 & 4,800 \\
30 & 990 & 1,500 & 1,900 & 2,500 & 2,900 & 3,400 \\
60 & 720 & 1,200 & 1,500 & 2,000 & 2,500 & 3,000 \\
90 & 570 & 930 & 1,200 & 1,700 & 2,000 & 2,500 \\
120 & 460 & 760 & 990 & 1,400 & 1,600 & 1,200 \\
183 & 320 & 520 & 670 & 890 & 1,100 & 1,300 \\
365 & 240 & 350 & 420 & 520 & 590 & 660 \\
\hline
\end{tabular}




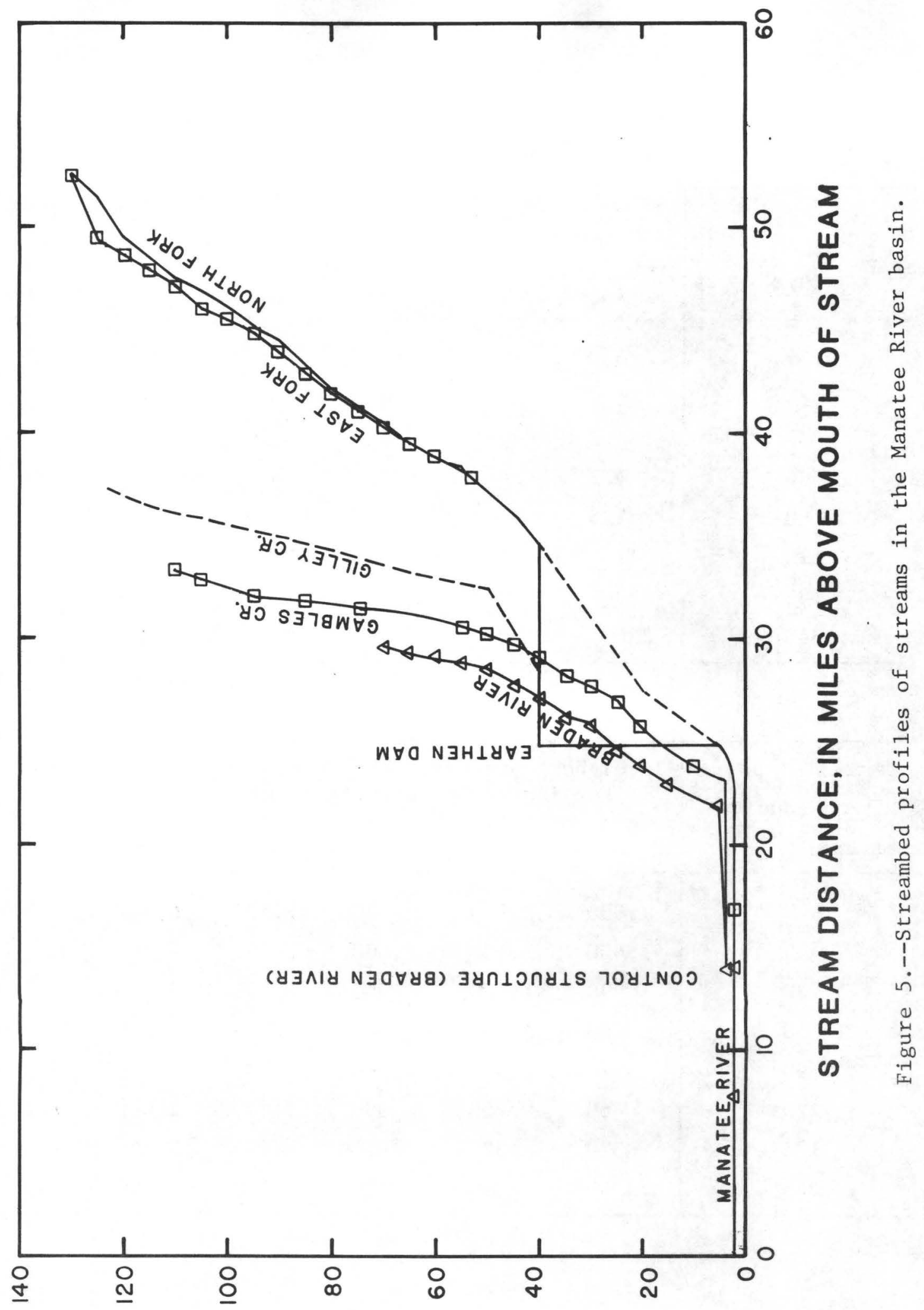

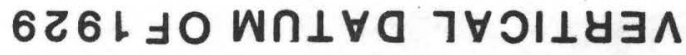

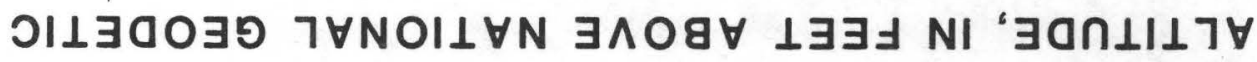


The flattening of the lower end of the flow-duration curve for Manatee River near Bradenton indicates that the stream has sustained flow. Base flow is sustained by drainage of ground water from the beds of fine sand and clay into which the stream is entrenched. The flattening of the flow-duration curve at high flows indicates detention and gradual release of water from storage in the small lakes and swamps following periods of intense rainfall.

The magnitude and frequency of annual low and high flows for Manatee River near Bradenton and near Myakka Head are presented in tables 6 and 7, respectively. The average anpual 7-day 2-year low flow at Bradenton and at Myakka Head are 4.0 and $1.0 \mathrm{ft}^{3} / \mathrm{s}$, respectively.

The Braden River, largest tributary to the Manatee River, rises in the 2 south-central part of Manatee ${ }_{2}$ County (fig. 2). The river drains about $76 \mathrm{mi}^{2}$ in the county and about $10 \mathrm{mi}^{2}$ in northern Sarasota County. The river is about 23 miles 1ong, and, at its source, the channel is about 70 feet above sea level (fig. 5).

\section{Little Manatee River Basin}

The Little Manatee River is about 39 miles long, heads in southeastern

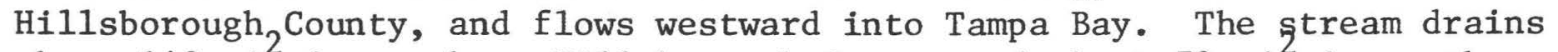
about $140 \mathrm{mi}^{2}$ in southern Hillsborough County and about $72 \mathrm{mi}^{2}$ in northern Manatee County (fig. 2). At its source, the channel is about 100 feet above sea level and has a fairly steep gradient. In its lower reaches, the stage rises and falls with tides in Tampa Bay. During low flow, tidal effects are discernible for about 15 miles upstream from its mouth.

From 1939 to 1977, the average discharge of the Little Manatee River near Wimauma was $172 \mathrm{ft} / \mathrm{s}$ or 15.5 inches of runoff per year (table 4). Flow ranged from a mipimum of $1.2 \mathrm{ft}^{3} / \mathrm{s}$ occurring on December 18-19, 1976, to a maximum of $14,000 \mathrm{ft} / \mathrm{s}$ occurring on September 11, 1960. The magnitude and frequency of annual low and high flows near Wimauma are presented in table 8.

The South Fork Little Manatee River, the largest tributary to the Little Manatee River, is about 14 miles 2 long and heads in northeastern Manatee County (fig. 2). It drains about $40 \mathrm{mi}^{2}$ in Manatee County and about $1 \mathrm{mi}^{2}$ in Hillsborough County. Its average discharge at Duette during the period 1956 to 1958 was $46.4 \mathrm{ft} / \mathrm{s}$ (Menke and others, 1961).

Lakes and Springs

Manatee County contains numerous small lakes and ponds that have a total surface area of less than 700 acres. Most lakes are shallow and may go dry during moderate droughts. The Florida Gazetteer, Part 3 (Florida Board of Conservation, 1969), lists 18 natural freshwater lakes in Manatee County. Cason Lake, with a surface area of 50 acres at a stage of 17 feet above sea level, is the largest lake reported. 
Table 6.--Magnitude and frequency of annual low and high flows, Manatee River near Bradenton

\begin{tabular}{c|r|r|c|c|c|c}
\hline \multirow{2}{*}{$\begin{array}{c}\text { Period } \\
\text { consecutive } \\
\text { days) }\end{array}$} & \multicolumn{5}{c}{$\begin{array}{c}\text { Lowest average flow, in cubic feet per second, } \\
\text { for indicated recurrence intervals, in years }\end{array}$} \\
\cline { 2 - 7 } & 2 & 5 & 10 & 20 & 50 & 100 \\
\hline 7 & 4.0 & 2.7 & 2.1 & 1.7 & 1.4 & 1.2 \\
15 & 4.4 & 2.9 & 2.3 & 1.9 & 1.6 & 1.4 \\
30 & 5.3 & 3.5 & 2.8 & 2.3 & 1.8 & 1.5 \\
60 & 7.8 & 4.8 & 3.6 & 2.9 & 2.3 & 1.9 \\
90 & 12 & 6.8 & 4.9 & 3.8 & 2.7 & 2.2 \\
120 & 16 & 8.4 & 5.9 & 4.4 & 3.1 & 2.5 \\
183 & 27 & 14 & 9.4 & 6.9 & 4.8 & 3.7 \\
365 & 99 & 68 & 56 & 48 & 41 & 36 \\
\hline
\end{tabular}

\begin{tabular}{c|r|r|r|r|rr}
\hline \multirow{2}{*}{$\begin{array}{c}\text { Period } \\
\text { consecutive } \\
\text { days) }\end{array}$} & \multicolumn{6}{c}{$\begin{array}{c}\text { Highest average flow, in cubic feet per second, } \\
\text { for indicated recurrence intervals, in years }\end{array}$} \\
\cline { 2 - 7 } & 2 & 5 & 10 & 25 & 50 & 100 \\
\hline 7 & 1,250 & 1,500 & 1,900 & 2,600 & 3,100 & 3,800 \\
15 & 620 & 940 & 1,200 & 1,500 & 1,800 & 2,100 \\
30 & 430 & 660 & 830 & 1,070 & 1,260 & 1,450 \\
60 & 320 & 500 & 650 & 860 & 1,030 & 1,220 \\
90 & 260 & 400 & 520 & 680 & 810 & 960 \\
120 & 210 & 330 & 420 & 560 & 660 & 780 \\
183 & 150 & 230 & 290 & 380 & 440 & 520 \\
365 & 99 & 140 & 180 & 220 & 250 & 290 \\
\hline
\end{tabular}


Table 7.--Magnitude and frequency of annual low and high flows, Manatee River near Myakka Head

\begin{tabular}{c|c|c|c|c|c|c}
\hline \multirow{2}{*}{$\begin{array}{c}\text { Period } \\
\text { consecutive } \\
\text { days) }\end{array}$} & \multicolumn{6}{c}{$\begin{array}{c}\text { Lowest average flow, in cubic feet per second, } \\
\text { for indicated recurrence intervals, in years }\end{array}$} \\
\cline { 2 - 7 } & 2 & 5 & 10 & 20 & 50 & 100 \\
\hline 7 & 1.0 & 0.5 & 0.3 & 0.2 & 0.1 & 0.1 \\
15 & 1.2 & 0.6 & 0.4 & 0.3 & 0.2 & 0.2 \\
30 & 1.5 & 0.7 & 0.5 & 0.4 & 0.3 & 0.2 \\
60 & 2.8 & 1.2 & 0.8 & 0.6 & 0.4 & 0.3 \\
90 & 4.9 & 2.2 & 1.5 & 1.1 & 0.8 & 0.7 \\
120 & 7.9 & 3.7 & 2.6 & 2.0 & 1.5 & 1.3 \\
183 & 12 & 5.4 & 3.8 & 2.9 & 2.1 & 1.8 \\
365 & 62 & 52 & 48 & 44 & 41 & 39 \\
\hline
\end{tabular}

\begin{tabular}{c|r|r|r|r|rrr}
\hline \multirow{2}{*}{$\begin{array}{c}\text { Period } \\
\text { consecutive } \\
\text { days) }\end{array}$} & \multicolumn{5}{|c}{$\begin{array}{c}\text { Highest average flow, in cubic feet per second, } \\
\text { for indicated recurrence intervals, in years }\end{array}$} \\
\cline { 2 - 7 } & 2 & 5 & 10 & 25 & 50 & 100 \\
\hline 7 & 720 & 860 & 940 & 1,030 & 1,080 & 1,100 \\
15 & 440 & 560 & 630 & 720 & 780 & 840 \\
30 & 290 & 390 & 450 & 520 & 580 & 630 \\
60 & 220 & 280 & 310 & 350 & 370 & 380 \\
90 & 170 & 210 & 240 & 270 & 290 & 320 \\
120 & 130 & 170 & 190 & 210 & 230 & 240 \\
183 & 95 & 110 & 120 & 140 & 140 & 150 \\
365 & 64 & 77 & 84 & 93 & 98 & 100 \\
\hline
\end{tabular}


Table 8.--Magnitude and frequency of annual low and high flows, Little Manatee River near Wimauma

\begin{tabular}{c|r|r|r|r|r|r}
\hline \multirow{2}{*}{$\begin{array}{c}\text { Period } \\
\text { consecutive } \\
\text { days) }\end{array}$} & \multicolumn{6}{c}{$\begin{array}{c}\text { Lowest average flow, in cubic feet per second, } \\
\text { for indicated recurrence intervals, in years }\end{array}$} \\
\cline { 2 - 7 } & 2 & 5 & 10 & 20 & 50 & 100 \\
\hline 7 & 8.4 & 4.5 & 3.1 & 2.2 & 1.4 & 1.1 \\
14 & 9.4 & 5.4 & 3.9 & 3.0 & 2.1 & 1.7 \\
30 & 12 & 7.2 & 5.6 & 4.6 & 3.6 & 3.1 \\
60 & 17 & 10 & 8.0 & 6.5 & 5.1 & 4.4 \\
90 & 25 & 15 & 11 & 8.7 & 6.7 & 5.6 \\
120 & 34 & 19 & 14 & 11 & 8.5 & 7.1 \\
183 & 49 & 26 & 19 & 15 & 12 & 9.7 \\
365 & 160 & 100 & 80 & 64 & 50 & 42 \\
\hline
\end{tabular}

\begin{tabular}{c|r|r|r|r|rr}
\hline \multirow{2}{*}{$\begin{array}{c}\text { Period } \\
\text { consecutive } \\
\text { days) }\end{array}$} & \multicolumn{6}{c}{$\begin{array}{c}\text { Highest average flow, in cubic feet per second, } \\
\text { for indicated recurrence intervals, in years }\end{array}$} \\
\cline { 2 - 7 } & \multicolumn{1}{|c|}{2} & 5 & 10 & 25 & 50 & 100 \\
\hline 7 & 1,400 & 2,300 & 2,900 & 3,700 & 4,300 & 4,900 \\
14 & 910 & 1,400 & 1,800 & 2,200 & 2,600 & 2,900 \\
30 & 650 & 1,020 & 1,260 & 1,500 & 1,700 & 1,900 \\
60 & 490 & 780 & 970 & 1,200 & 1,400 & 1,500 \\
90 & 380 & 620 & 770 & 950 & 1,080 & 1,200 \\
120 & 310 & 500 & 630 & 780 & 880 & 980 \\
183 & 230 & 360 & 440 & 530 & 600 & 660 \\
365 & 160 & 240 & 280 & 330 & 370 & 400 \\
\hline
\end{tabular}


Several springs were reported by Ferguson and others (1947). In a revision of Ferguson's work by Rosenau and others (1977), no springs were reported in the county as the springs reported by Ferguson are now dry.

\section{Ground Water}

Ground water is water in the zone of saturation--the zone in which all interconnected voids, large and small, are filled with water under pressure greater than atmospheric pressure (Lohman and others, 1972). Ground water in Manatee County occurs under unconfined and confined conditions. The unconfined ground water is water in an aquifer that has a water table, the surface being at atmospheric pressure. The confined ground water is under pressure, and its upper limit is the bottom of a confining bed that has a distinctly lower hydraulic conductivity than the material in which the confined water occurs.

A11 stratigraphic units underlying Manatee County yield some water to wells, but the water-yielding properties differ considerably among units. Units have been classified hydrologically as aquifers or confining beds.

\section{Surficial Aquifer}

The surficial aquifer is composed primarily of deposits of sand, gravel, shells, and limestone whose composition may vary laterally and vertically. The deposits comprise the Holocene sediments, Pleistocene terrace deposits, the Caloosahatchee (?) Mar1, and the Bone Valley Formation.

In the eastern and central part of Manatee County, the aquifer consists mostly of medium- to fine-grained, well-sorted, quartz sand and ranges in thickness from about 10 to 90 feet (fig. 6). Within this area, the sands contain a hardpan layer that consists of sand and carbonaceous and limonitic material that averages about 5 feet in thickness. The hardpan retards vertical flow of water. The sandy clays of the Bone Valley Formation and the Hawthorn Formation form the base of the surficial aquifer in eastern Manatee County.

In the western part of the county, the aquifer consists of sand, sandy limestone, and shell and ranges from about 1 to 20 feet in thickness. The sandy clays, clays, and marls form the base of the surficial aquifer.

\section{Transmissivity and storage coefficient}

Transmissivity and storage coefficients of the surficial aquifer were estimated by comparing the type of material comprising the aquifer with laboratory hydraulic conductivity and specific-yield values and aquifer tests run in similar materials in nearby areas.

The transmissivity of the surficial aquifer probably ranges from less than $100 \mathrm{ft}^{2} / \mathrm{d}$ to about $10,000 \mathrm{ft} / \mathrm{d}$. Transmissivity of the thick sand and phosphorite deposits in the south-central part of the county probably ranges from 1,000 


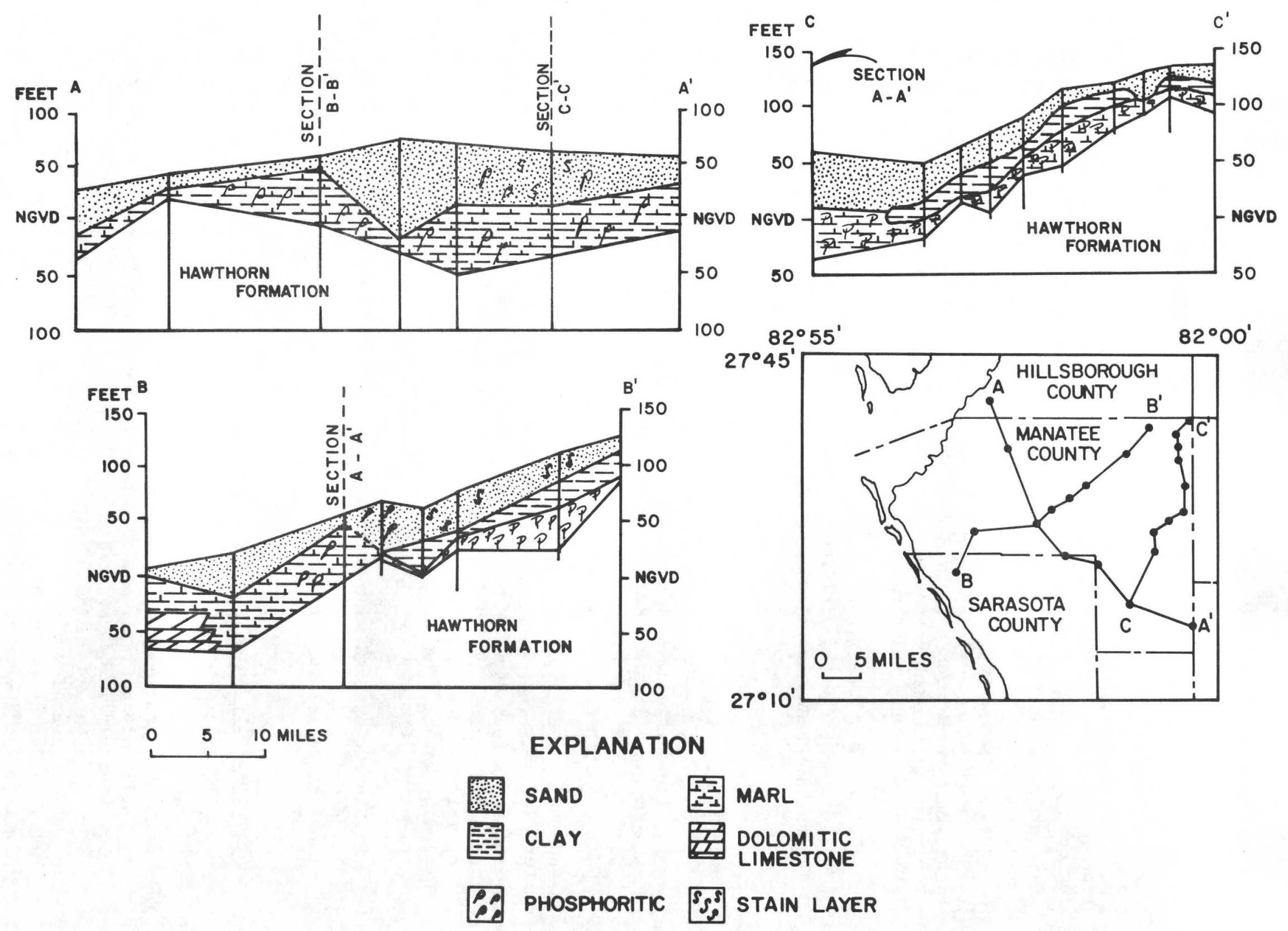

Figure 6.--Geologic sections showing surficial material overlying the Hawthorn Formation. 
to about 2,000 $\mathrm{ft}^{2} / \mathrm{d}$. Similar transmissivity was reported by Wilson (1972) and Hutchinson and Wilson (1974) for surficial deposits in DeSoto and Hardee Counties. Transmissivity of a surficial aquifer in Charlotte County, south of Manatee County, that consists of sand and interbedded shell and limestones similar to deposits in western Manatee County was reported to be about 7,000 ft $/ \mathrm{d}$ (Sutcliffe, 1975). The transmissivity of the surficial aquifer in adjacent counties, determined from aquifer tests, ranged from about 200 to $1,800 \mathrm{ft} / \mathrm{d}$ (R. M. Wolansky, written commun., 1977).

The specific yield of an unconfined aquifer generally ranges between 0.1 and 0.3. The average specific yield of an unconfined aquifer for long periods of draining is about 0.2 (Lohman, 1972, p. 8). Specific yields determined in the surficial aquifer in Polk County ranged from 0.125 to 0.47 (Pride and others, 1966). Laboratory determinations of specific yield in Hillsborough County ranged from about 0.2 to 0.4 (Sinclair, 1974).

The storage coefficient of an unconfined aquifer is virtually equal to the specific yield, which is commonly determined by laboratory drainage tests. In Manatee County, the storage coefficient of the surficial aquifer is estimated to range from about 0.05 to 0.25 based on laboratory specific-yield tests of similar deposits in Polk County (Pride and others, 1966) and in Hillsborough County (Sinclair, 1974) and on an aquifer test in southeastern Hillsborough County (Hutchinson, 1977).

Ground-water movement, recharge, and discharge

The general configuration of the water table in the surficial aquifer for a low-water period, May 1975, is shown in figure 7. The direction of groundwater flow is generally west and south. The configuration of the water surface is similar to that of the land surface. Water surface is at sea level along the coast and increases to altitudes of about 130 feet in the northeast.

Depth to the water table ranges from zero in coastal and flat, poorly drained areas to about 10 feet below land surface in topographically high areas. The average depth to the water table is about 5 feet. Seasonal fluctuations in the water table are generally less than 5 feet (fig. 8). Water levels are generally lowest in April or May and highest in September.

In some areas, the surficial aquifer is confined by layers of hardpan, clay, or limestone. Many shallow wells in the county penetrate one or more of these confining layers. Generally, the artesian pressure is insufficient to produce flowing wells (Peek, 1958b).

Infiltrating rainwater recharges the surficial aquifer. Of the 55 in/yr average rainfall, an estimated 39 inches is lost to evapotranspiration and about 15 inches runs off in streams. The remaining inch infiltrates the soil and recharges the surficial aquifer. This represents an estimated $17.4 \mathrm{Mgal}$ of water per square mile that recharges the aquifer in an average year.

Recharge to the surficial aquifer also results from upward leakage of water from confined aquifers where the potentiometric surface is higher than the water table. Some recharge occurs as influent seepage from impounded 


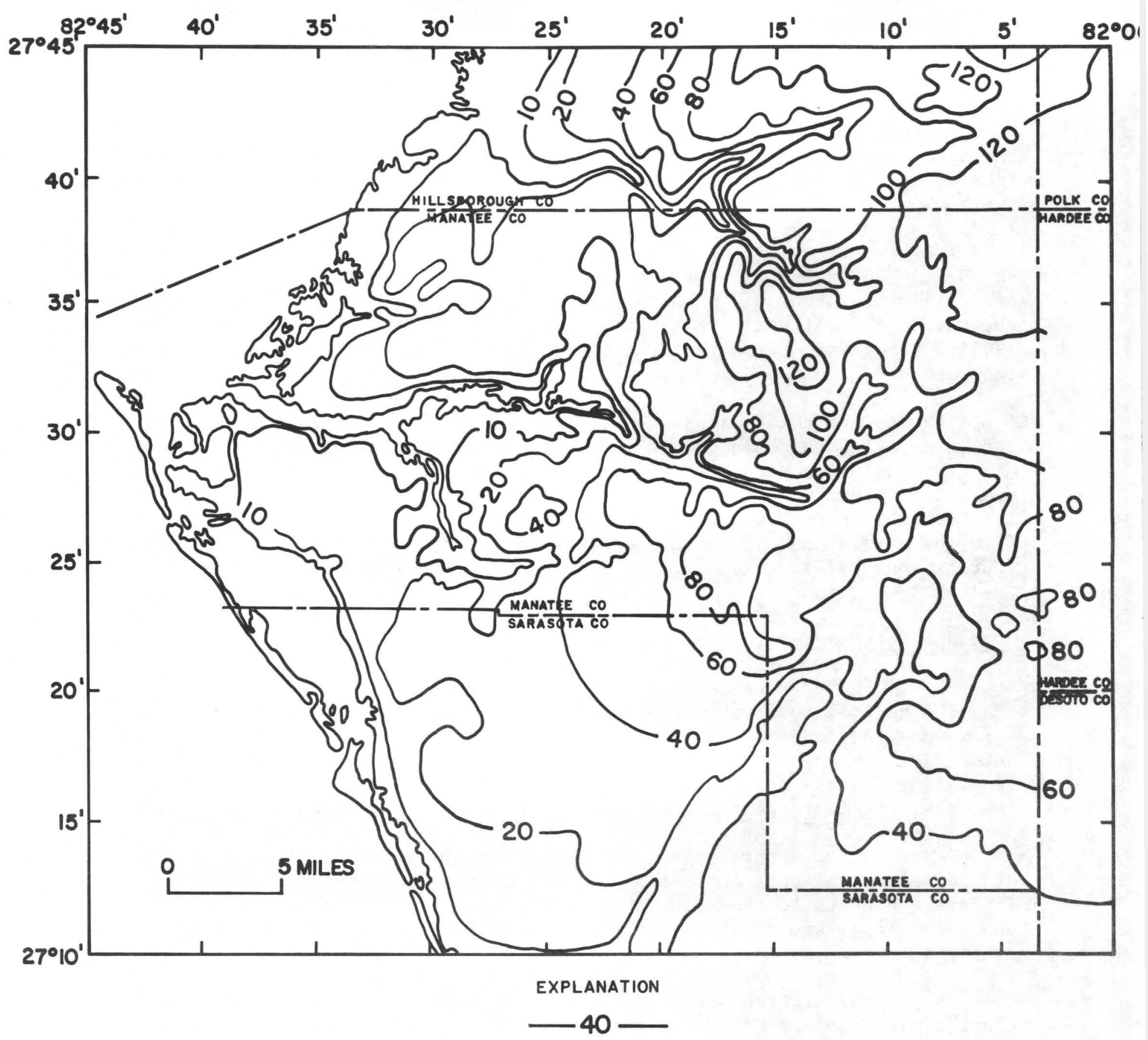

WATER-TABLE CONTOUR--SHOWS ALTITUDE OF WATER TABLE. CONTOUR INTERVAL 20 FEET. SUPPLEMENTAL IO-FOOT CONTOUR LINE. DATUM IS NGVD OF 1929

Figure 7.--Generalized water table, May 1975. 


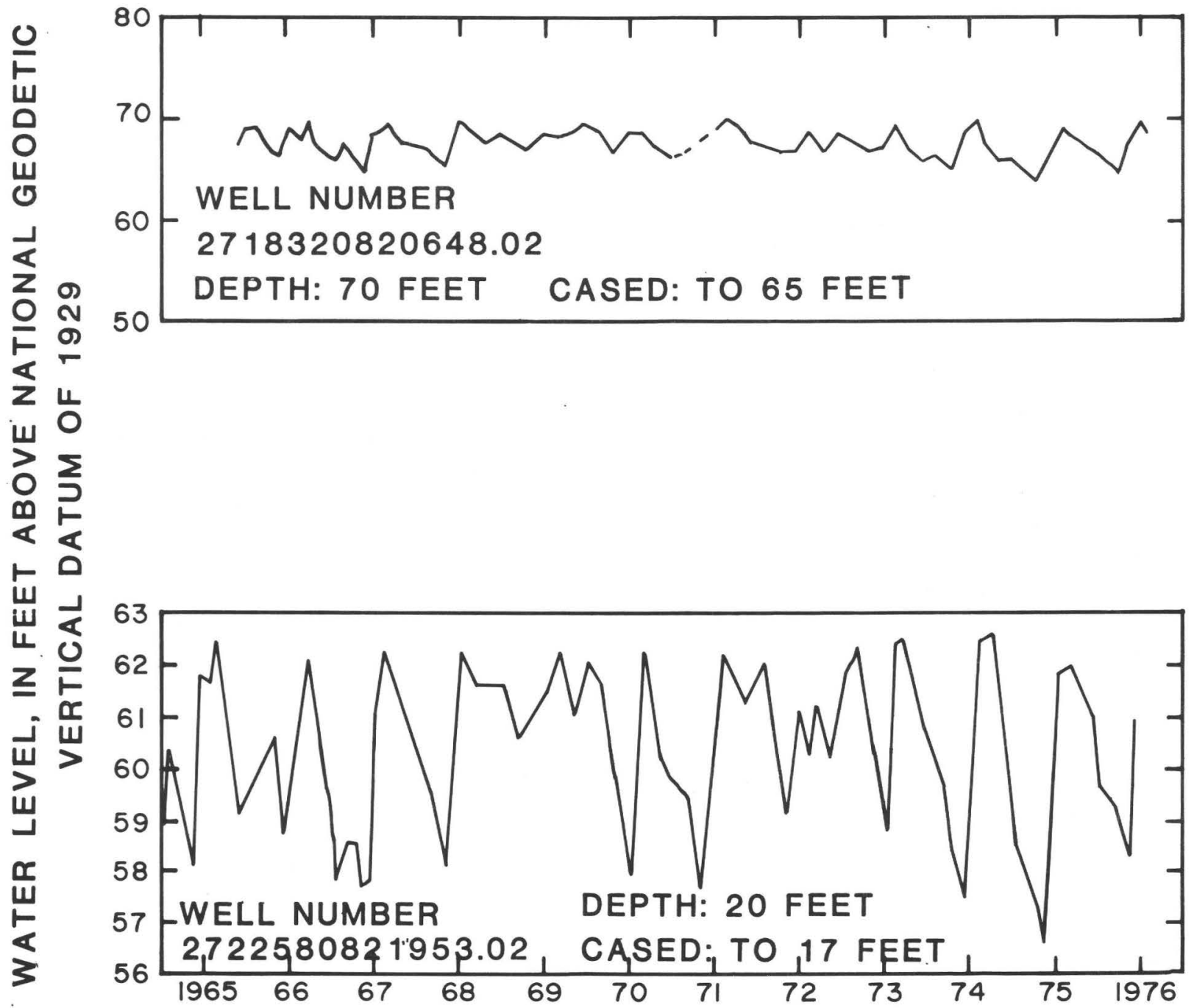

Figure 8.--Water levels in wells penetrating the surficial aquifer. 
streams or streams at high stage. Also, artificial recharge occurs by infiltration of irrigation water, discharge from septic tanks, and infiltration of water from flowing or improperly constructed wells.

Discharge from the surficial aquifer is by evapotranspiration, seepage into surface-water bodies, downward leakage to underlying aquifers when the water table is higher than the potentiometric surface, and ground-water outflow to adjacent areas. Artificial discharge comes from pumpage, inflow into drainage ditches and canals, and by drainage by improperly constructed wells.

\section{Upper Confining Bed and Minor Artesian Aquifer}

The upper confining bed consists of sandy clay, clay, and marl and retards vertical movement of water between the surficial and the Floridan aquifers. The bed thickens from about 200 feet in the northern part of the county to about 375 feet in the southern part (figs. 9 and 10).

The minor artesian aquifer occurs within the upper confining bed. The aquifer consists of discontinuous beds of permeable sand, gravel, shell, and limestone within the upper part of the Hawthorn Formation. The top of the aquifer is between zero and 300 feet below sea level. The sand and shell beds, primarily quartz, phosphate minerals, and shell fragments, are generally less than 10 feet thick. Limestone beds are hard, sandy, fossiliferous, and dolomitic and range from about 10 to 50 feet in thickness.

The minor artesian aquifer in the Myakka River basin, which includes the southeastern part of Manatee County, was called Artesian Zone 2 by Joyner and Sutcliffe (1976). Wilson (1977a) described these beds in Hardee and DeSoto Counties as the upper unit of the Floridan aquifer.

Transmissivity, storage coefficient, and leakance

Estimated transmissivity derived from aquifer tests analyses of the minor artesian aquifer ranges from less than 1,000 to $11,500 \mathrm{ft} / \mathrm{d}$ (R. M. Wolansky, written commun., 1977). The transmissivity in the northeastern part of the county, however, is generally less than $1,000 \mathrm{ft} / \mathrm{d}$. The storage coefficient of the minor artesian aquifer ranges from $4 \times 10^{-5}$ to $3 \times 10^{-4}$. Estimated leakance $f$ rom the surficial aquifer to the minor artesian aquifer ranges from $10^{-5}$ to $10^{-3}(\mathrm{ft} / \mathrm{d}) / \mathrm{ft}$ (R. M. Wolansky, written commun., 1977).

Ground-water movement, recharge, and discharge

Ground-water flow is generally westward. In May 1977, water levels ranged from about 10 feet above sea level in coastal areas to about $100 \mathrm{feet}$ in the northeast (fig. 11). In September 1977, water levels ranged from about 20 to 100 feet above sea level (fig. 12). Seasonal water-level fluctuations range from less than 5 feet in the northeast and coastal areas to about 20 feet near the Verna well field in south-central Manatee County. 


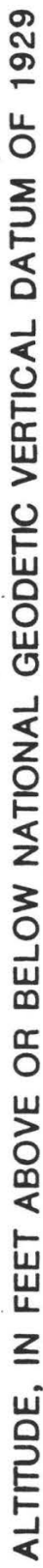

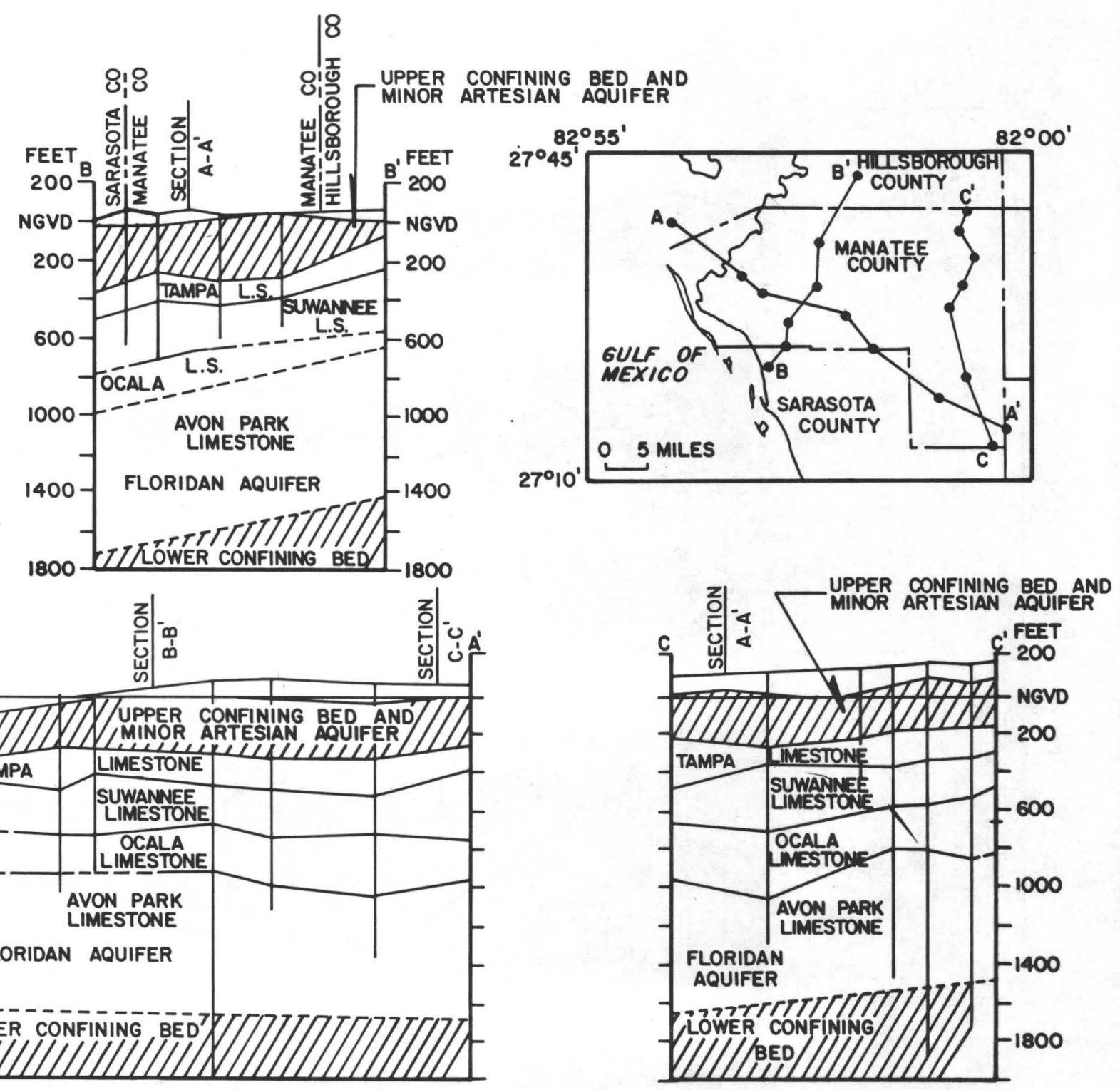

Figure 10.--Hydrogeologic sections. 


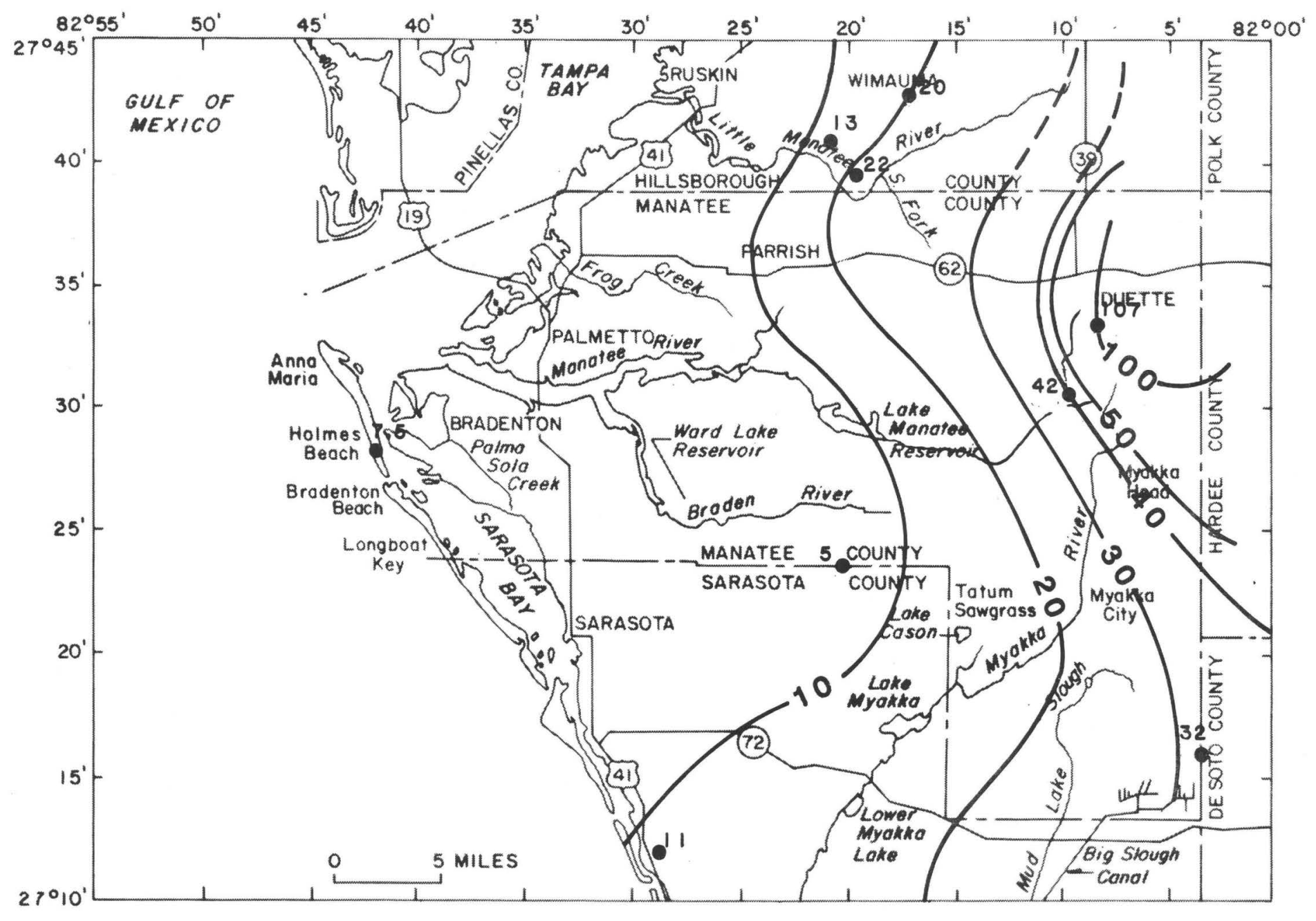

\section{EXPLANATION}

$10-$

POTENTIOMETRIC CONTOUR- SHOWS ALTITUDE AT WHICH WATER LEVEL WOULD HAVE STOOD IN TIGHTLY CASED WELLS. DASHED WHERE APPROXIMATELY LOCATED. CONTOUR INTERVAL 10 AND 50 FEET. DATUM IS NGVD OF 1929

\section{$0^{5}$ \\ WELL WITH WATER - LEVEL ALTITUDE}

Figure 11.--Potentiometric surface of the minor artesian aquifer, May 1977. 


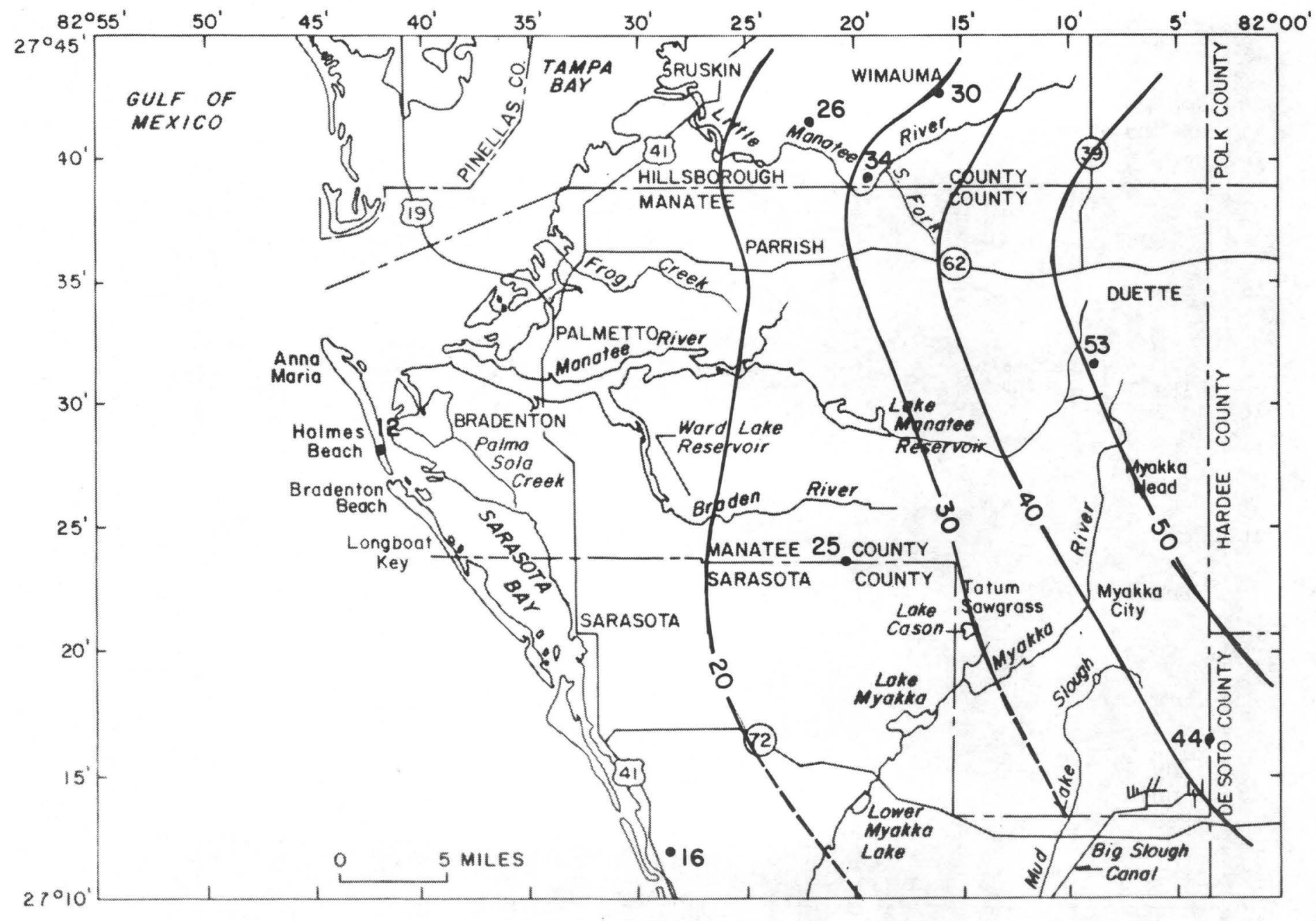

\section{EXPLANATION}

POTENTIOMETRIC CONTOUR--SHOWS ALTITUDE AT WHICH WATER-LEVEL WOULD HAVE STOOD IN TIGHTLY CASED WELLS. DASHED WHERE APPROXIMATELY LOCATED. CONTOUR

INTERVAL 10 FEET. DATUM IS NGVD OF 1929

- 26

WELL WITH WATER-LEVEL ALTITUDE

Figure 12.--Potentiometric surface of the minor artesian aquifer, September 1977. 
Recharge to the minor artesian aquifer occurs both by downward leakage from the surficial aquifer, where the water table is higher than the potentiometric surface of the minor artesian aquifer, and by upward leakage from the Floridan aquifer, where the potentiometric surface of the Floridan aquifer is higher than the potentiometric surface of the minor artesian aquifer.

Discharge from the aquifer occurs by (1) downward leakage to the Floridan aquifer, where the potentiometric surface of the minor artesian aquifer is higher than the potentiometric surface of the Floridan aquifer; (2) by upward leakage to the surficial aquifer, where the potentiometric surface is higher than the water table; (3) ground-water outflow to the gulf or adjacent areas; (4) pumpage; and (5) flowing wells.

\section{Floridan Aquifer}

The Floridan aquifer, principal source of ground water in Manatee County, is composed of a thick, stratified sequence of limestone and dolomite (Miocene to Eocene in age). The aquifer includes the Tampa Limestone, Suwannee Limestone, Ocala Limestone, and the Avon Park Limestone (fig. 10). Permeable limestone beds of the Hawthorn Formation that are in hydrologic contact with the underlying Tampa Limestone are also included.

The altitude of the top of the Floridan aquifer ranges from about 200 feet below sea level in the northern part of the county to about 350 feet below sea level in the southern part (fig. 13). The aquifer thickens from about 1,000 feet in the western part of the county to 1,700 feet in the southern part (fig. 14).

The limestone and dolomite sequence generally functions as a single hydrologic unit; however, three distinct water-bearing zones are known to exist within the sequence. The highly permeable layers of the zones generally occur at or near formation contacts. The zones are separated by beds of low permeability that act as semiconfining beds retarding vertical movement of water.

The upper, middle, and lower zones of the Floridan aquifer correlate with zones 3, 4, and 5 as described by Joyner and Sutcliffe (1976). The upper zone includes permeable rock in the lower part of the Hawthorn Formation and the upper part of the Tampa limestone. The zone consists of sand, sandy limestone, clay, and hard limestone layers that contain dark phosphatic pebbles. This zone underlies the entire county and is generally less productive in the northeast than in the western part of the county.

The middle zone consists of the lower part of the Tampa Limestone, all of the Suwannee Limestone, and the upper part of the Ocala Limestone. Depth to this zone ranges from about 300 feet in the northeastern part of the county to about 500 feet in the southern part. The more permeable layers of the zone occur at the formation contacts of the Tampa and Suwannee Limestones and the Suwannee and Ocala Limestones.

The Ocala Limestone, which is 300 to 400 feet thick and of low vertical permeability, generally acts as a semiconfining bed. It retards vertical movement of water between the lower zone and the middle zone. 


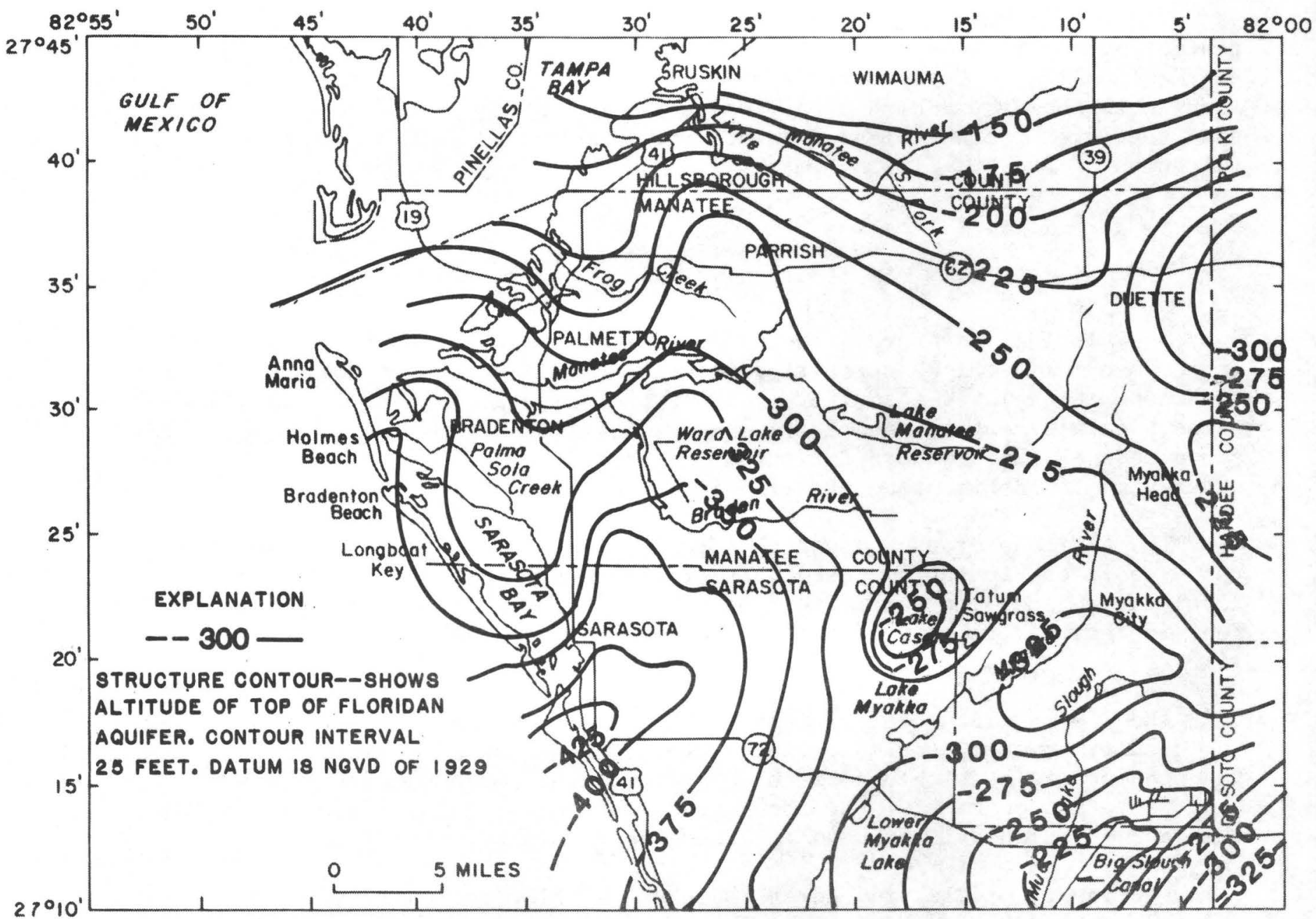

Figure 13.--Altitude of the top of the Floridan aquifer (modified from Buono and Rutledge, 1978). 


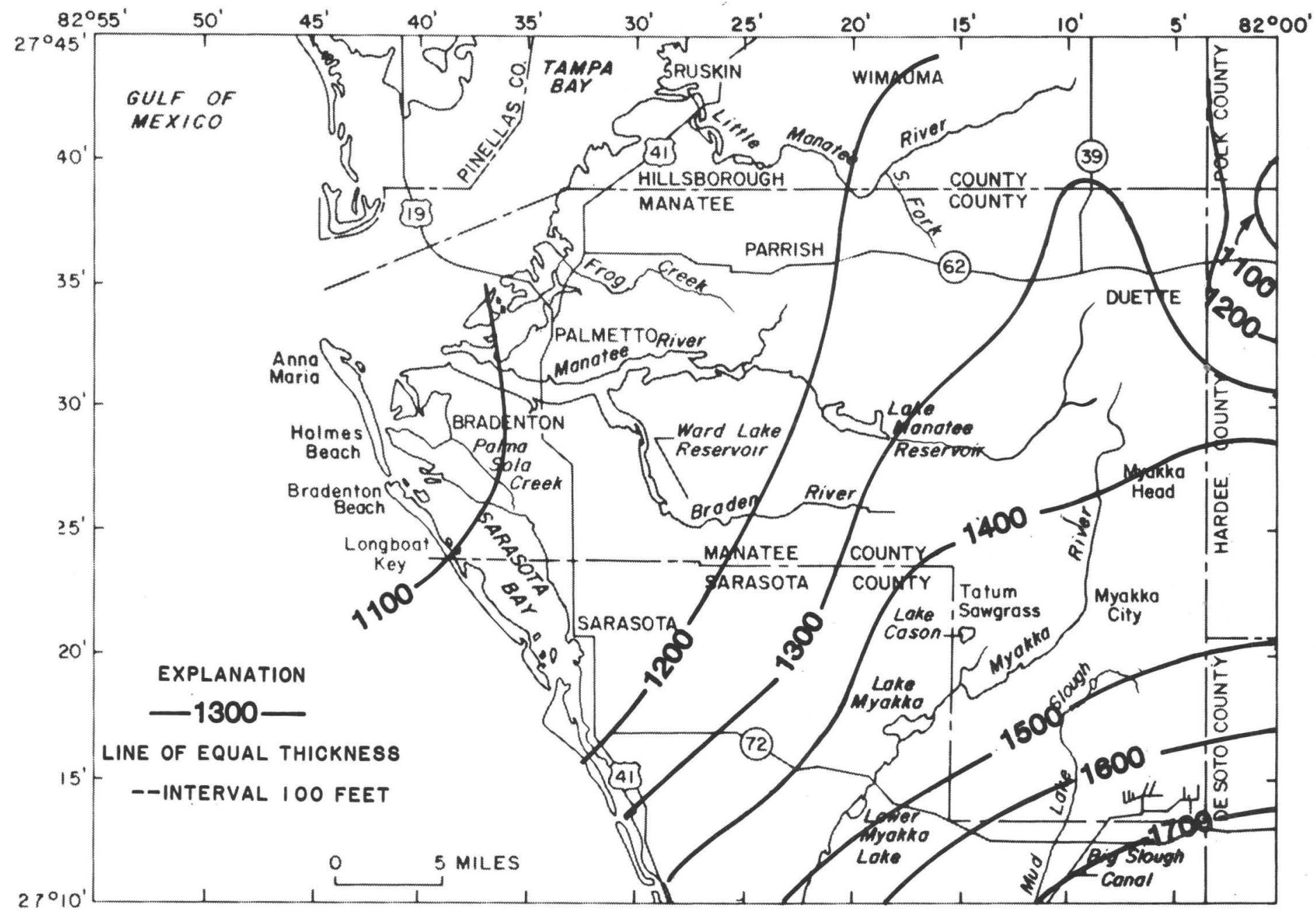

Figure 14.--Thickness of the Floridan aquifer (modified from Wilson, 1977). 
The lower zone consists of permeable limestone and dolomitic rock in the Avon Park Limestone. It is the major water-bearing zone of the Floridan aquifer throughout southwest Florida. The lower zone underlies the county at depths ranging from about 900 feet below land surface in the north to about 1,200 feet below land surface in the south. This zone is separated from the overlying zones by the lower part of the Ocala Limestone.

Transmissivity, storage coefficient, and leakance

The transmissivity of the Floridan aquifer ranges from about 40,000 to $900,000 \mathrm{ft}^{2} / \mathrm{d}$ (R. M. Wolansky, written commun., 1977). Transmissivity of the dolomite unit of the Avon Park Limestone lower water-bearing zone ranges from about 20,000 to $700,000 \mathrm{ft}^{2} / \mathrm{d}$. Most production wells, however, are also open to the lower part of the middle zone (Ocala Limestone). In eastern and southeastern Maqatee County, the transmissivity of this zone ranges from 60,000 to $150,000 \mathrm{ft}^{2} / \mathrm{d}$.

In western Manatee County, the transmissivity of the upper and middle zones is about 15,000 $\mathrm{ft}^{2} / \mathrm{d}$ (Peek, 1958a). In northeastern Manatee County, William F. Guyton and Associates (1976d) reported an estimated transmissivity of about 3,300 $\mathrm{ft}^{2} / \mathrm{d}$ for the Suwannee Limestone and also indicated that little water can be produced from the Tampa Limestone.

$10^{-3}$ Storage coefficients of most confined aquifers range from about $10^{-5}$ to $10^{-3}$ and are about $10^{-6}$ per foot of thickness (Lohman, 1972) 3 The storage coefficient of the Floridan aquifer ranges from 1.0 to $1.7 \times 10^{-3}$ (R. M. Wolansky, written commun., 1977).

Leakance from the surficial aquifer to the Floridan aquifer where differences in head are favorable could not be determined accurately from aquifer tests. This was due to (1) extreme thickness of the upper confining beds (about 200 to $400 \mathrm{feet}$ ), (2) small drawdowns due to high transmissivity of the aquifer, (3) large fluctuations in background water levels due to seasonal irrigation, and (4) short duration of most aquifer tests (fess than 30 days). Leakance to the Floridan aguifer is probably less than $10^{-4}(\mathrm{ft} / \mathrm{d}) / \mathrm{ft}$ and is estimated to range from $10^{-6}$ to $10^{-5}$ ( $\mathrm{ft} / \mathrm{d}$ ) / ft. Estimated leakances determined from aquifer tests range from $10^{-6}$ to $10^{-3}(\mathrm{ft} / \mathrm{d}) / \mathrm{ft}$. In northeastern Manatee County, William F. Guyton and Associates (1976d) estimated leakance to be about $1.34 \times 10^{-6}$ to $1.34 \times 10^{-5}(\mathrm{ft} / \mathrm{d}) / \mathrm{ft}$.

Ground-water movement, recharge, and discharge

The regional configuration of the potentiometric surface is shown in figure 15. The general configuration of the potentiometric surface as shown for September 1975 has changed 1ittle since 1961 (Healy, 1962) or as mapped by Stringfield in 1934 (Stringfield, 1936), but there has been a general downward trend in water levels since 1955. Ground-water flow is perpendicular to and toward potentiometric surfaces of lower altitude. Ground-water flow in the county is generally west and southwest from the regional high located about 30 miles northeast of the county. 


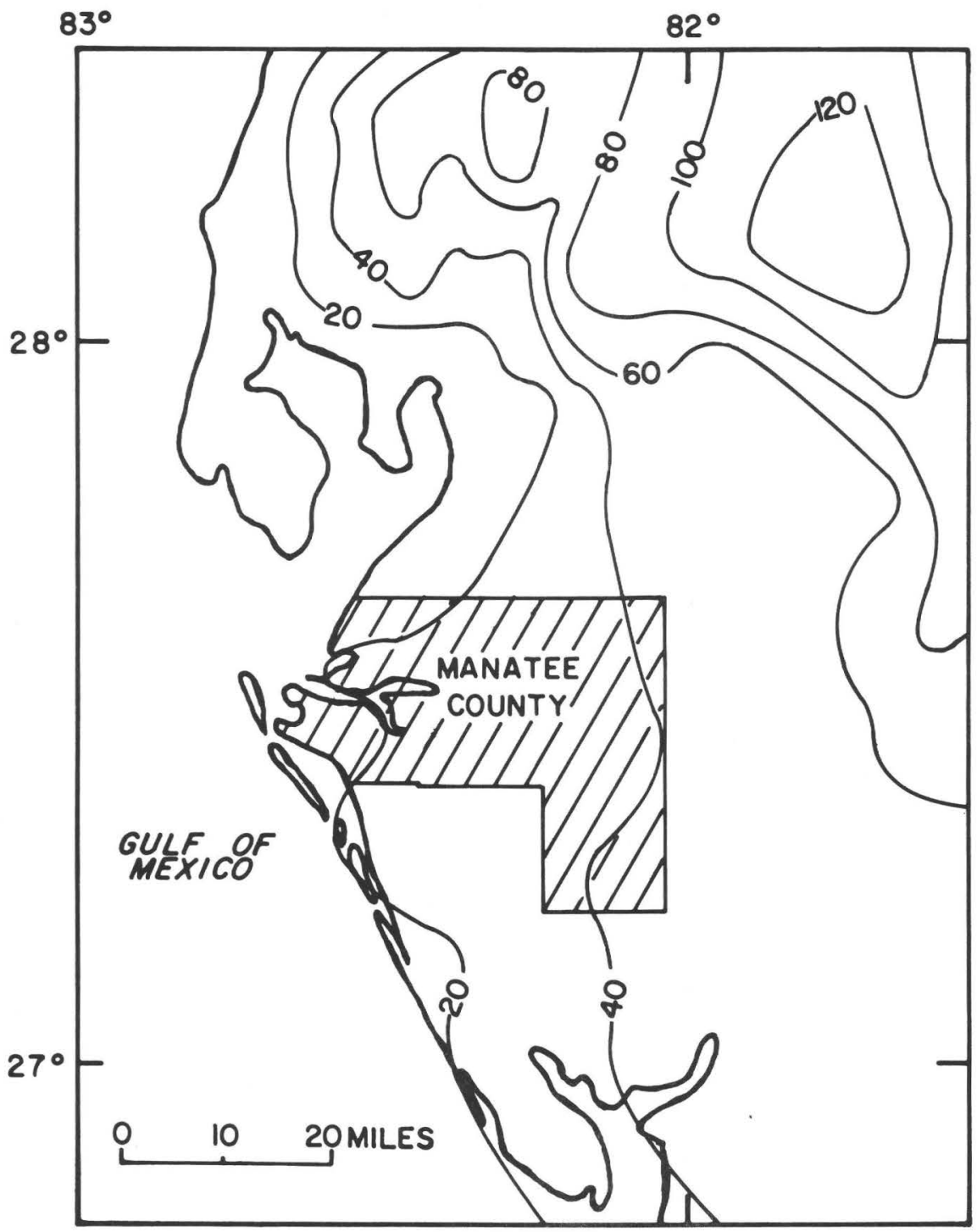

\section{EXPLANATION} 60

POTENTIOMETRIC CONTOUR --

Shows altitude at which water level would have stood in tightly cased wells. Contour interval 20 feet. Datum is NGVD of 1929

Figure 15.--Potentiometric surface of the Floridan aquifer, west-central Florida, September 1975 (modified from Mills and others, 1976). 
In May 1975, during a period of heavy pumpage on the order of 40 to 50 $\mathrm{Mgal} / \mathrm{d}$, the potentiometric surface ranged from about 10 feet below sea level in the central part of the county to about 30 feet above sea level in the southeastern part (fig. 16). The depression in the potentiometric surface in the central part of the county probably resulted from ground-water withdrawals for irrigation. At the coast, the potentiometric surface is relatively high because ground-water withdrawals there are smal1. In September 1975, during a period of relatively low pumpage on the order of 5 to $10 \mathrm{Mgal} / \mathrm{d}$, the potentiometric surface ranged from about 20 feet above sea level near the coast to about 40 feet in the east (fig. 17). Figure 18 shows areas of artesian flow in May and September 1975.

Seasonal fluctuations of the potentiometric surface are in response to changes in recharge and discharge. The potentiometric surface is generally lowest in April or early May, near or at the end of the dry season, when groundwater withdrawals are at a maximum. The potentiometric surface is generally highest in September near the end of the rainy season when ground-water withdrawals are minimal. The magnitude of seasonal fluctuations from May 1975 to September 1975 ranged from 5 feet near the coast to about 30 feet in the northeast (fig. 19).

From the early 1950 's to the 1970 's, the magnitude of seasonal fluctuations has increased. Peek (1958a) in 1954-55 reported seasonal fluctuations of about 5 feet and in some areas as much as $10 \mathrm{feet.} \mathrm{Hydrographs} \mathrm{of} \mathrm{water} \mathrm{levels} \mathrm{in}$ selected wells show fluctuations of 30 feet in the middle 1970's (fig. 20) compared to less than 20 feet in the early and middle 1950's (Peek 1958a). The increase in fluctuations is probably due to increased ground-water withdrawals and below-normal rainfall since 1960 .

From September 1954 to September 1975, the potentiometric surface decline ranged from 5 feet near the coast to about 20 feet in the northeast (fig. 17). From June 1955 to May 1975, the decline ranged from less than 5 feet near the coast to about 50 feet in the northeast (fig. 16). The estimated decline of the potentiometric surface from May 1969 to May 1975 ranged from less than 5 feet near the coast to about 40 feet in the northeast (Mills and Laughlin, 1976).

Hydrographs of observation wells (fig. 20) indicate a general downward trend of seasonal peaks during 1965-75. Declines range from about 5 feet in northern Sarasota County (well I) to 15 feet in western Hardee County (well G). The potentiometric surface in Manatee County showed little or no decline from 1934 to 1954 (Stringfield, 1966; Peek, 1958a), but from 1954 to 1975, declines ranged from about 5 feet near the coast to 20 feet in the northeast. Most of the decline occurred from 1965 to 1975 and is probably due to increased groundwater withdrawals and below normal rainfall.

Recharge to the Floridan aquifer is generally from infiltration of precipitation through the semiconfining beds and from surface runoff into sinkholes in the central Florida highlands area, about 40 miles northeast and east of Manatee County (Stringfield, 1966). Thus, most of the water in the Floridan aquifer in Manatee County is from inflow from adjacent areas. In eastern Manatee County, some recharge occurs as downward leakage of water from the surficial and minor artesian aquifers where the potentiometric surface of the Floridan aquifer is lower than the water table and the potentiometric surface of the minor artesian aquifers. In May 1975, the computed downward leakage 


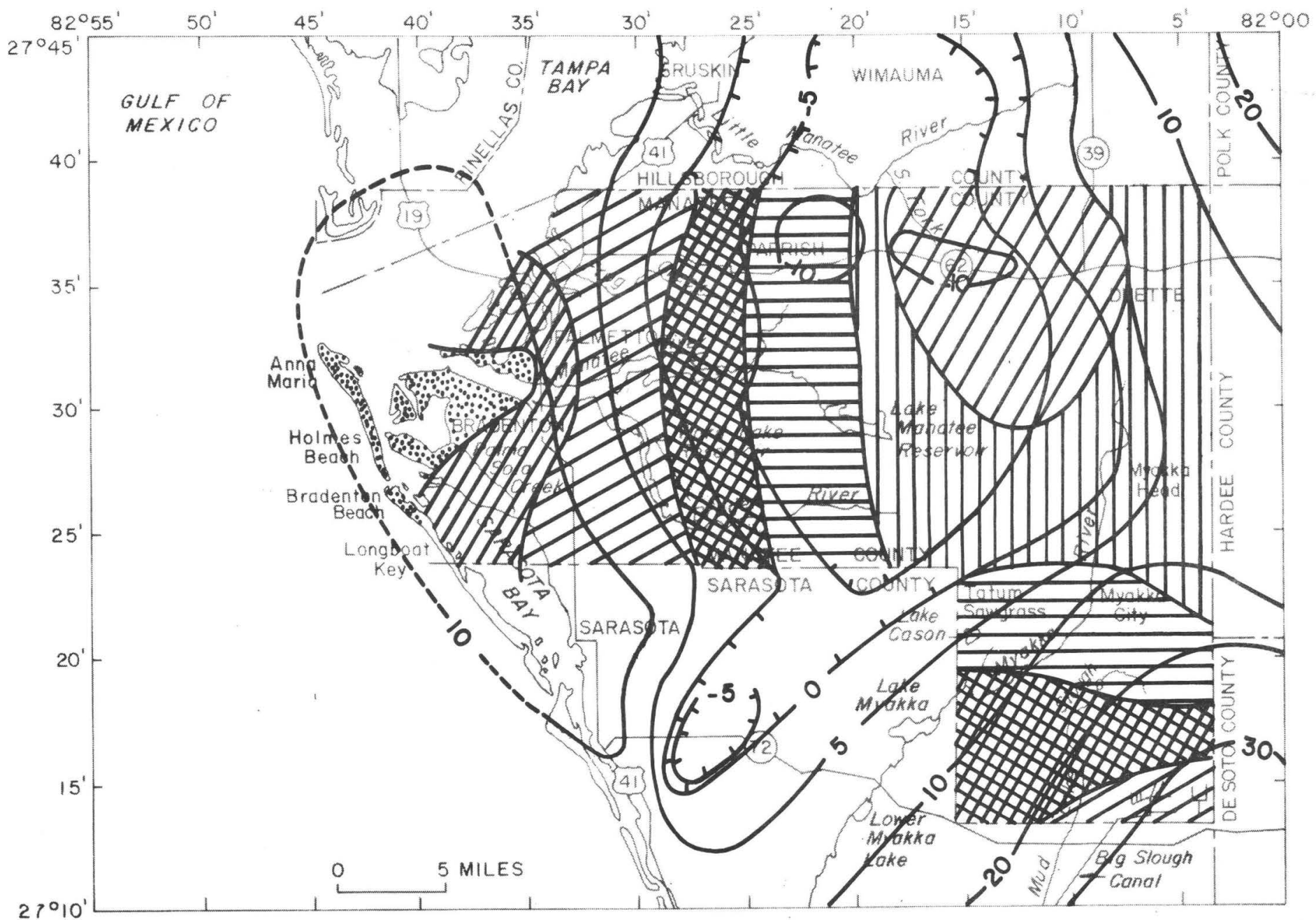

EXPLANATION

$-10-$

POTENTIOMETRIC CONTOUR--8HOWS ALTITUDE AT WHICH WATER LEVEL WOULD HAVE $8 T 000$ W TIGHTLY CABED WELL8. CONTOUR INTERVAL 5 AND 10 FEET. DATUM 18 NOVD OF 1929

RANGE OF DECLINE IN THE POTENTIOMETRIC BURFACE, IN FEET

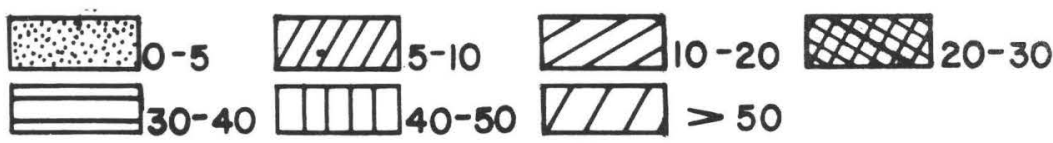

Figure 16.--Potentiometric surface of the Floridan aquifer, May 1975, and decline in the potentiometric surface, June 1955 to May 1975. 


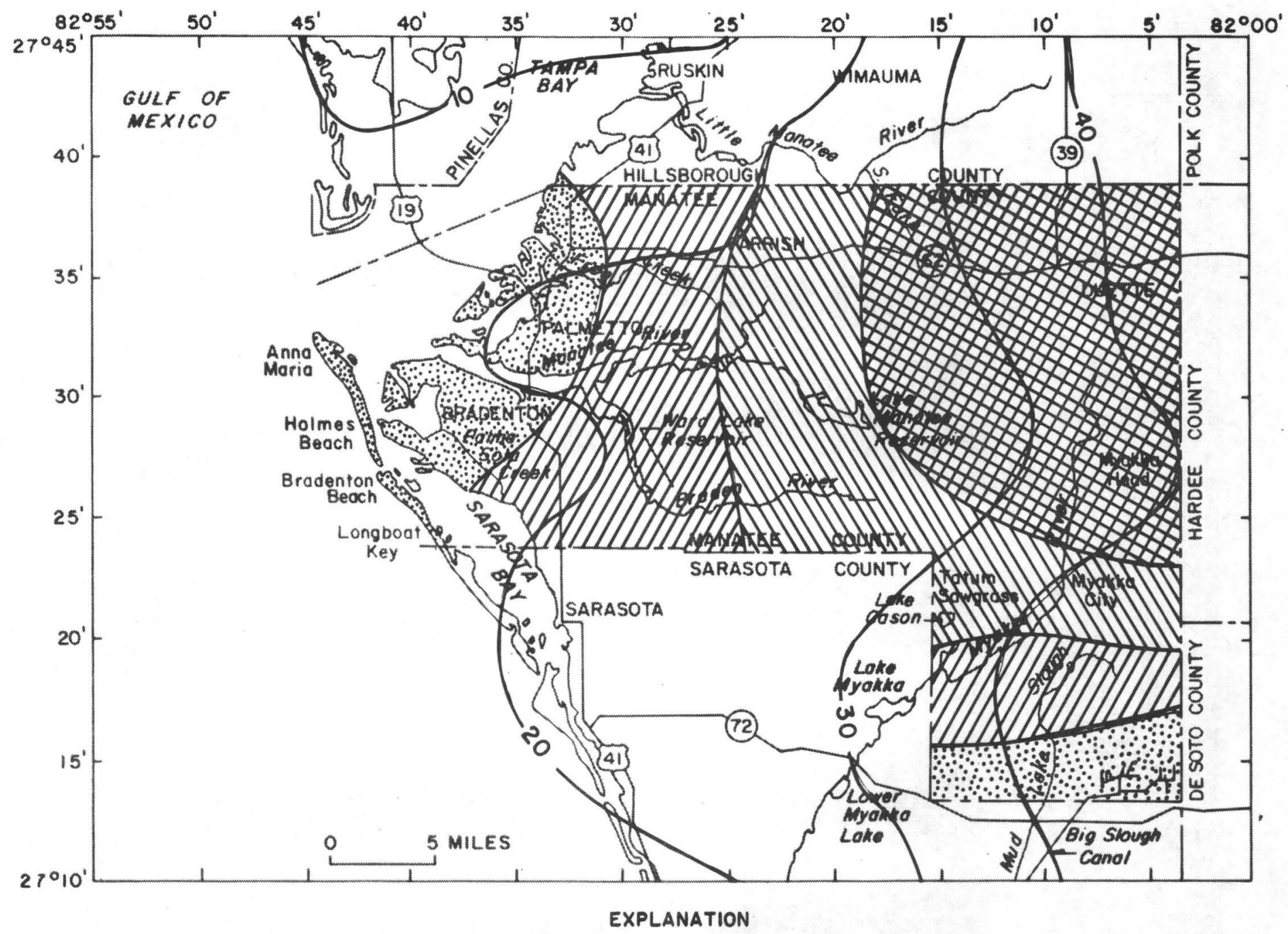

POTENTIOMETRIC CONTOUR--SHOWS ALTITUDE AT WHICH WATER LEVEL WOULD HAVE STOOD IN TIGHTLY CASED WELLS. CONTOUR INTERVAL 10 FEET. DATUM IS NOVD OF 1929

RANGE OF DECLINE. IN THE POTENTIOMETRIC SURFACE, IN FEET

0-5

Figure 17.--Potentiometric surface of the Floridan aquifer, September 1975, and decline in the potentiometric surface, September 1954 to September 1975. 


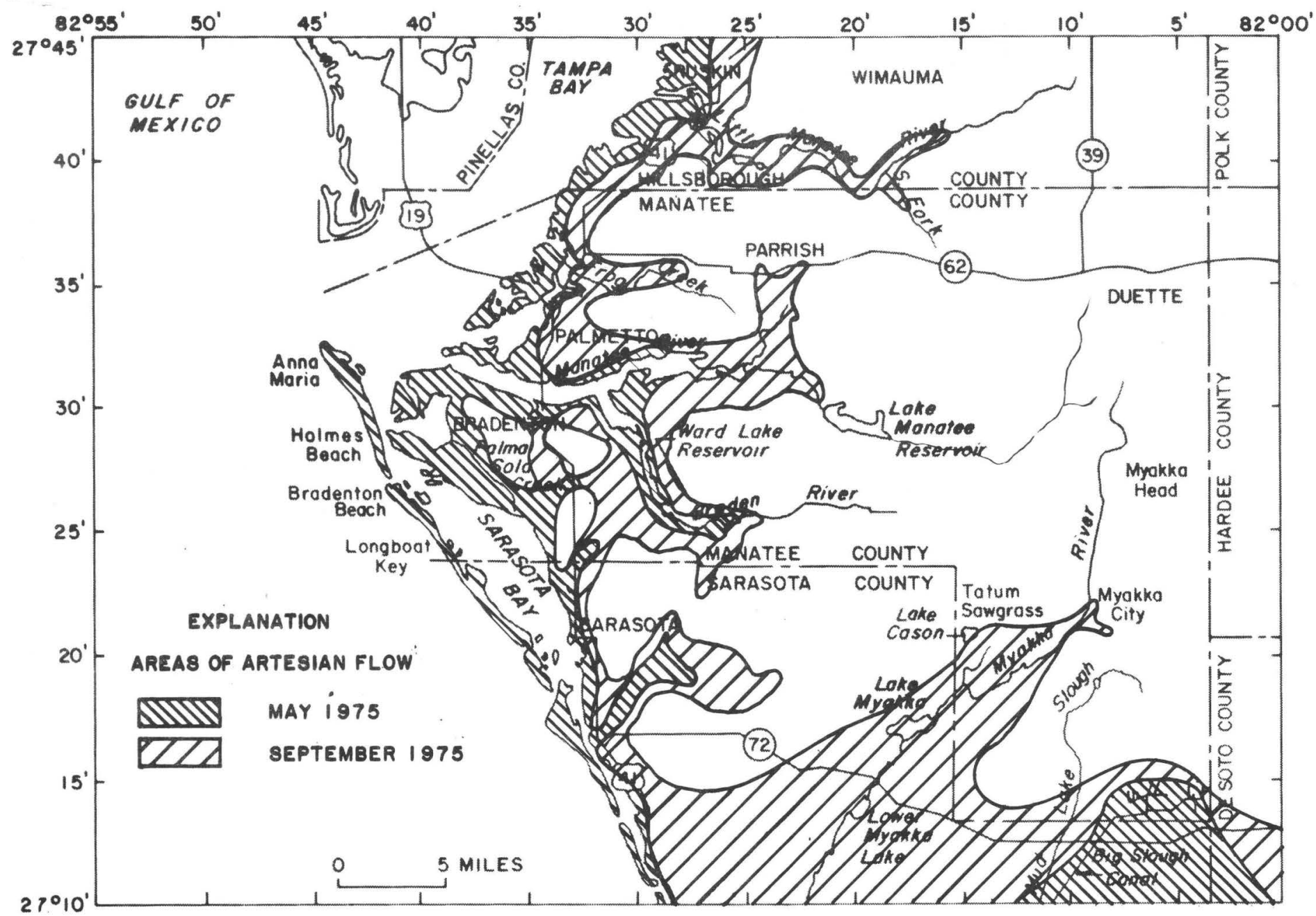

Figure 18.--Areas of artesian flow, May and September 1975. 


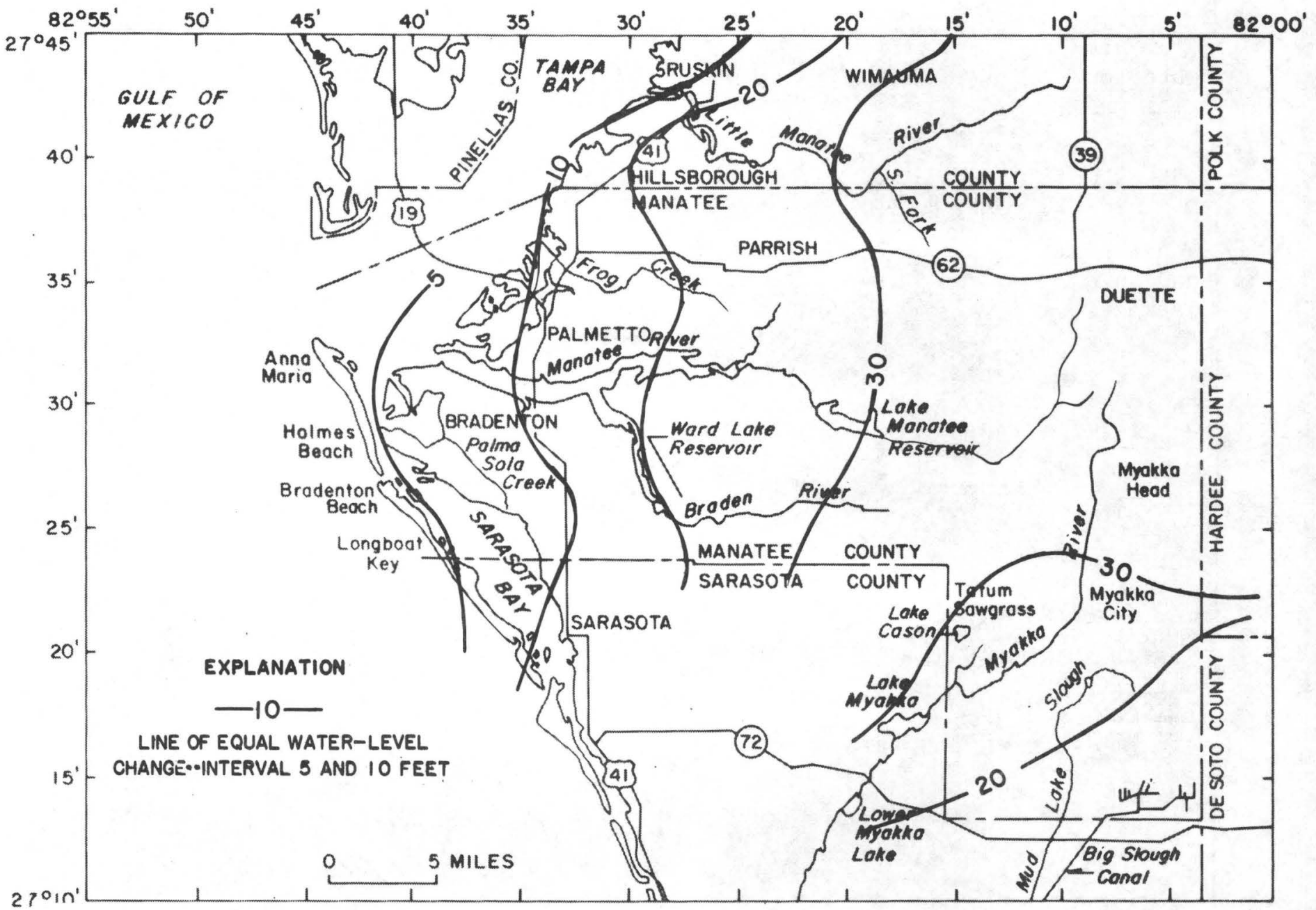

Figure 19.--Change in potentiometric surface, May 1975 to September 1975. 
from the surficial aquifer to the Floridan aquifer over the $700-\mathrm{mi}^{2}$ area of downward leakage in Manatee County and parts of adjacent counties east of the coast was about $12 \mathrm{Mgal} / \mathrm{d}$, based on an estimated leakance of $1.3 \times 10^{-6}(\mathrm{ft} / \mathrm{d}) / \mathrm{ft}$ and an average head difference of 60 feet. In September 1975, computed downward leakage was about $6 \mathrm{Mgal} / \mathrm{d}$ for an average head difference of 30 feet for the same area and leakance.

Discharge from the Floridan aquifer is primarily from pumpage, groundwater outflow to adjacent areas or the gulf, and upward leakage to the surficial and minor artesian aquifers. A small amount of discharge comes from uncapped, flowing, and improperly constructed wells, especially in coastal and inland areas where the potentiometric surface of the Floridan aquifer is above land surface. In May 1975, the computed upward leakage from the Floridan aquifer to the surficial aquifer over the $200-\mathrm{mi}^{2}$ area of artesian flow along the coast was about $0.1 \mathrm{Mgal} / \mathrm{d}$, based on an estimated leakance of $1.3 \times 10^{-6}(\mathrm{ft} / \mathrm{d}) / \mathrm{ft}$ and an average head difference of 2 feet. In September 1975, computed upward leakage was about $0.5 \mathrm{Mgal} / \mathrm{d}$ for an average head difference of 9 feet for the same area and leakance.

\section{Lower Confining Bed}

The Lake City Limestone, although a major source of ground water in some parts of Florida, is permeated with evaporites within the intergranular pore space and acts as the lower confining bed of the Floridan aquifer system in Manatee County. The upper part of the Lake City Limestone contains highly mineralized water and is described as having a very low permeability (William $\mathrm{F}$. Guyton and Associates, 1976d). The unit retards vertical movement of mineralized water from deeper zones and forms the base of the Floridan aquifer. The top of the Lake City Limestone ranges from about 1,400 feet below sea level in the northwest to 1,900 feet in the southeast (fig. 21).

\section{Quality of Water}

Surface and ground water in Manatee County contain dissolved minerals in varying amounts that affect the quality of water. The mineral constituents and the degree of mineralization depend on composition and solubility of soil and rock through which water passes and upon duration of contact. Water with a low dissolved mineral concentration is generally more suitable for most purposes than water with a high mineral concentration. The source and significance of various constituents and properties of water are discussed in detail by Hem (1970). Those properties that have a practical bearing on water use are summarized in "Water Resources Data for Florida--Water Year 1976" (U.S. Geological Survey, 1977).

\section{Surface Water}

Surface water in Manatee County is generally less mineralized than ground water except in tidally affected and coastal areas. The quality of surface water is suitable for most purposes; however, the quality varies seasonally. 

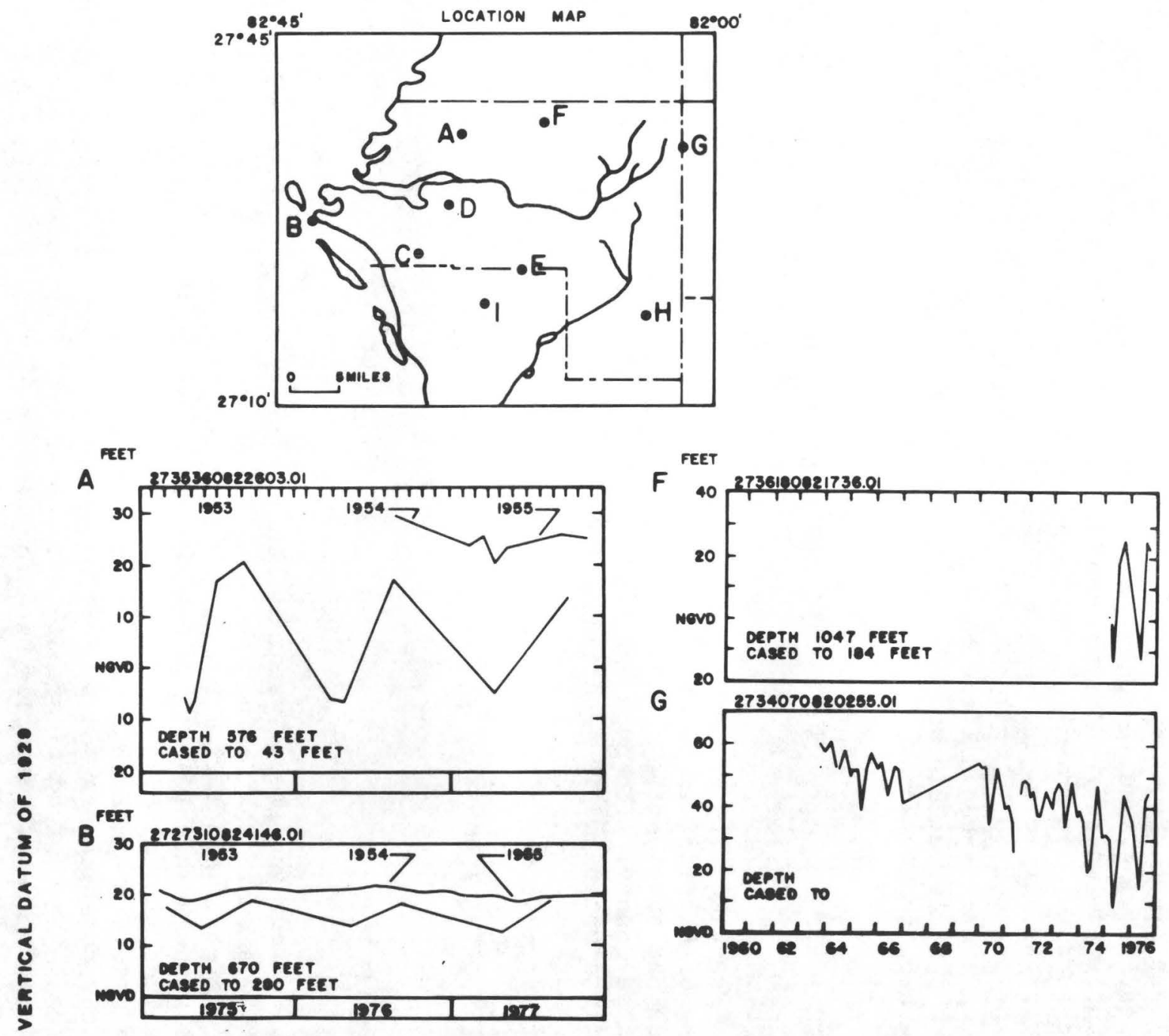


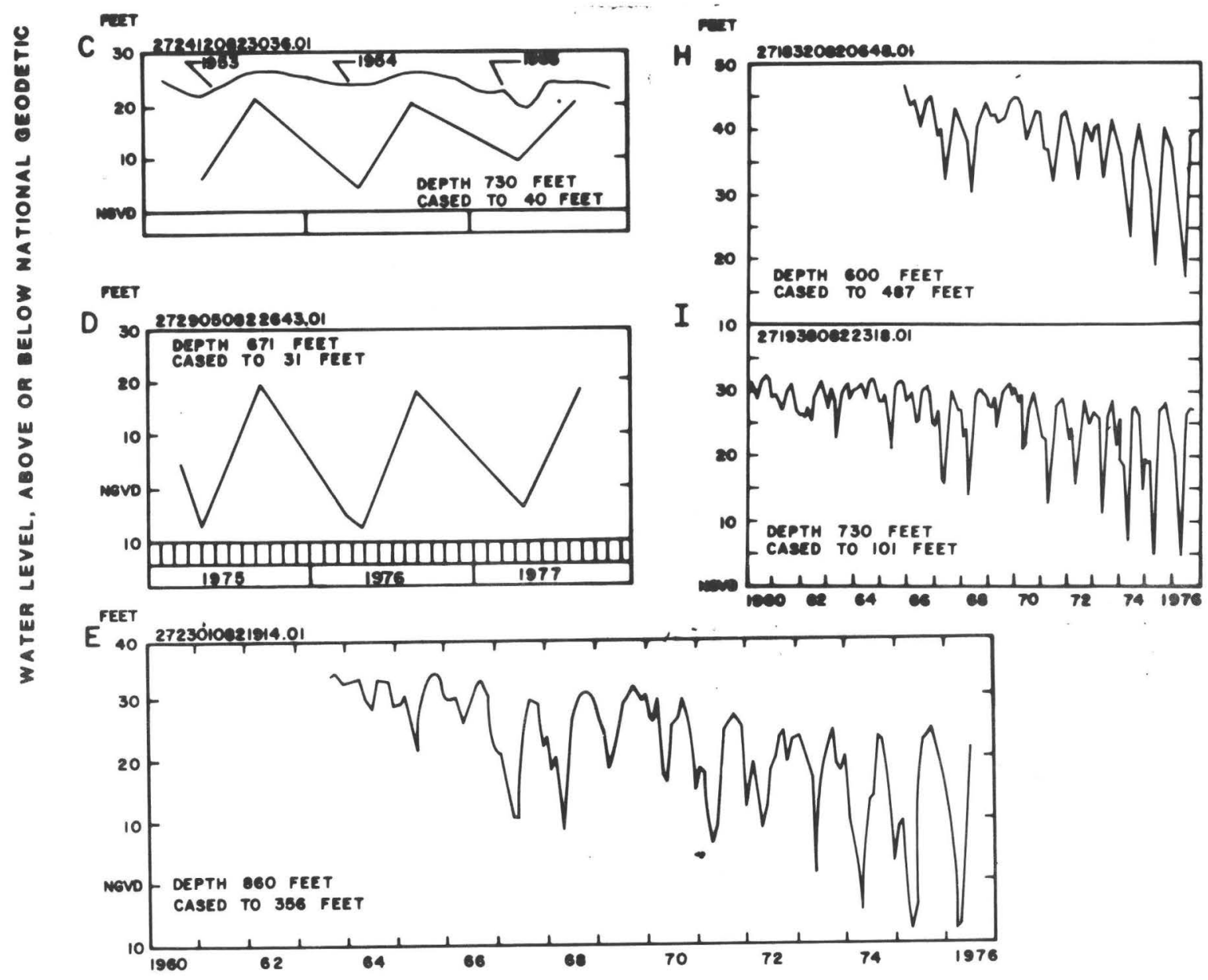

Figure 20.--Water levels in selected wells penetrating the Floridan aquifer. 


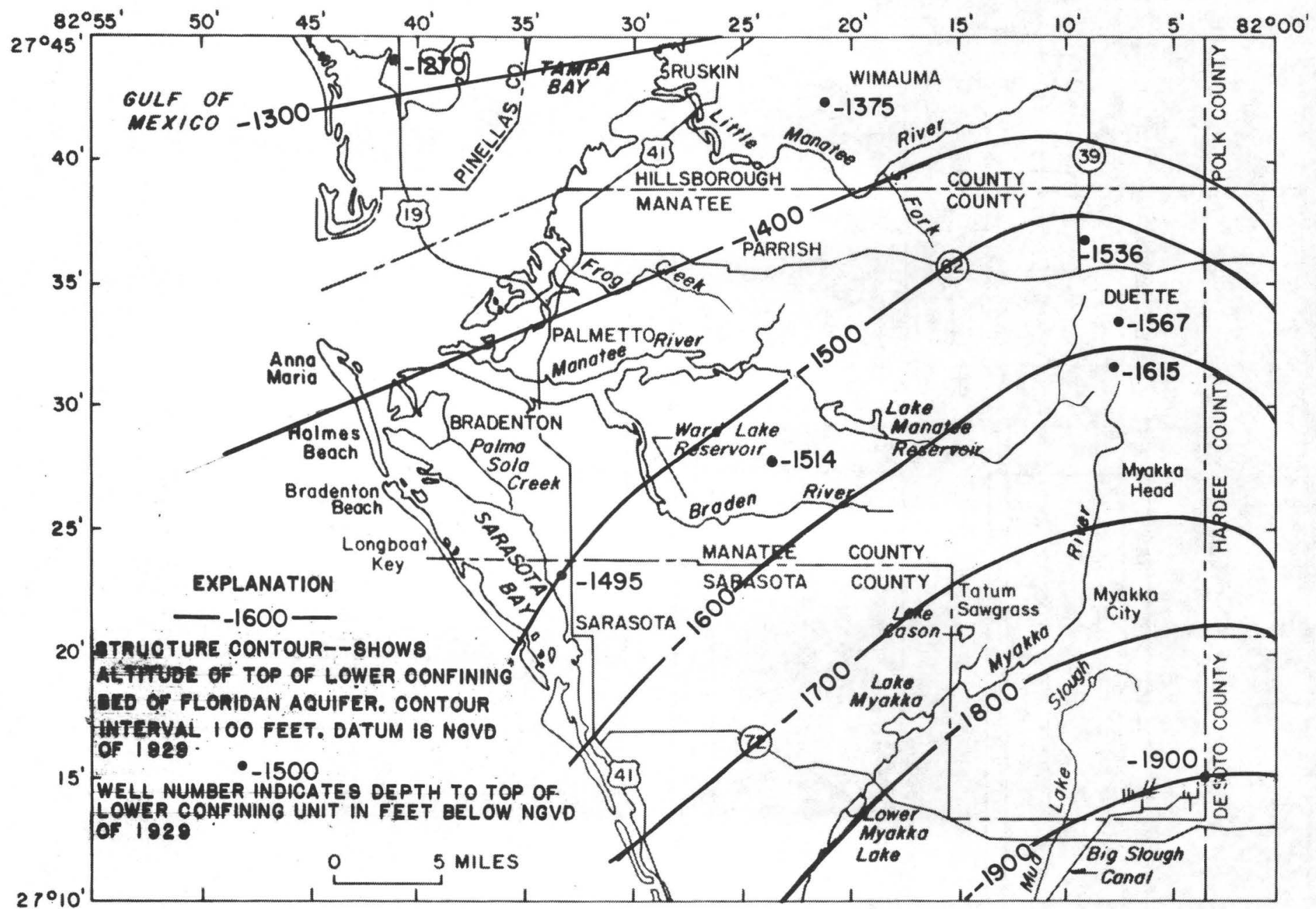

Figure 21.--Altitude of the top of the lower confining bed of the Floridan aquifer system. 
Surface-water quality analyses discussed in this report were obtained from U.S. Geological Survey Annual Summary reports (1956-76). During the wet season (June through September), streamflow is composed mainly of runoff, and dissolved mineral concentrations and hardness are lowest. The color of the water, caused in part by decomposition and leaching of organic matter, becomes higher as streamflow increases and is highest in the wet season. During the dry season (October to May), flow of streams is maintained by ground-water discharge, and dissolved mineral concentrations and hardness increase and color decreases. Many streams also derive flow from runoff of irrigation water originating from wells that tap aquifers yielding water having high dissolved solids. Therefore, streams receiving irrigation wastewater tend to be moderately high in dissolved minerals.

The ranges in concentration for selected water-quality parameters for Myakka River near Sarasota, Manatee River near Myakka Head, Manatee River near Bradenton, and Little Manatee River near Wimauma are presented in table 9. The concentrations for chloride, sulfate, dissolved solids, and hardness are within the limits established by the U.S. Environmental Protection Agency (1976) for public water supplies. However, color exceeded 75 platinum-cobalt units, the recommended upper limit for drinking water. Figure 22 shows the seasonal variations of discharge, color, iron, $\mathrm{pH}$, and specific conductance for the Manatee River near Bradenton from October 1964 to September 1965.

During low flow, calcium and magnesium bicarbonate are the dominant chemical constituents present in surface waters in upland areas, whereas, calcium, magnesium and sulfate, and sodium chloride dominate in coastal and low-lying areas (Kaufman, 1972). Calcium and magnesium bicarbonate water is generally associated with Tertiary carbonate terrane in central Florida or may be derived from agricultural runoff or discharge from the Floridan or minor artesian aquifers. Calcium and magnesium sulfate water may be derived from agricultural runoff or may result from discharge from gypsiferous aquifers. Sodium chloride is associated with saline water in the low-lying coastal areas of tidal and estuarine environments. It may also be derived from excess irrigation runoff or discharge from wells penetrating saline water in aquifers.

\section{Ground Water}

The chemical quality of ground water is primarily affected by the quality of water recharged to the aquifer, types of rocks in which water is in contact, and length of time water has been circulating within the aquifers. In Manatee County, the chemical quality is also affected by intrusion of seawater or the mixing of relatively fresh water with highly mineralized water, believed to be residual seawater within the water-bearing formations (Peek, 1958a).

Wells that penetrate deep water-bearing zones are commonly constructed with tens to hundreds of feet of open hole and are open to one or more waterbearing zones. Water in each zone has distinctive water-quality characteristics. Thus, the quality of water pumped depends on which zones are tapped and the proportion of water derived from each. 
Tab1e 9.--Range in concentration for selected water-quality parameters for streams in Manatee County and adjacent areas

\begin{tabular}{|c|c|c|c|c|c|c|c|c|}
\hline Sampling site & $\begin{array}{l}\text { Period } \\
\text { of } \\
\text { record }\end{array}$ & $\begin{array}{c}\text { Chloride, } \\
\text { Cl } \\
(\mathrm{mg} / \mathrm{L})\end{array}$ & $\begin{array}{c}\text { Sulfate, } \\
\text { So } \\
\left(\mathrm{mg}^{4} \mathrm{~L}\right)\end{array}$ & $\begin{array}{l}\text { Dissolved } \\
\text { solids } \\
(\mathrm{mg} / \mathrm{L})\end{array}$ & $\begin{array}{l}\text { Hardness } \\
\text { as } \mathrm{CaCO} \\
(\mathrm{mg} / \mathrm{L})^{4}\end{array}$ & $\begin{array}{l}\text { Specific } \\
\text { conductance } \\
\text { (umho/cm } \\
\text { at } 25^{\circ} \mathrm{C} \text { ) }\end{array}$ & $\begin{array}{l}\text { Color } \\
\text { (Pt-Co } \\
\text { units) }\end{array}$ & $\begin{array}{c}\text { Tempera- } \\
\text { ture } \\
\left({ }^{\mathrm{C}}\right)\end{array}$ \\
\hline $\begin{array}{l}\text { Myakka River near } \\
\text { Sarasota }\end{array}$ & $\begin{array}{l}1962-66 \\
1967-76\end{array}$ & $\begin{array}{l}3.0-24 \\
5 \cdot 5-90\end{array}$ & $\begin{array}{l}0-8.6 \\
0.8-71\end{array}$ & $\begin{array}{l}18-67 \\
59-235\end{array}$ & $\begin{array}{l}10-38 \\
15-120\end{array}$ & $\begin{array}{l}41-182 \\
42-418\end{array}$ & $\begin{array}{l}60-210 \\
60-320\end{array}$ & $\begin{array}{r}9-27 \\
13-33\end{array}$ \\
\hline $\begin{array}{l}\text { Manatee River near } \\
\text { Myakka Head }\end{array}$ & $1967-76$ & $3 \cdot 5-16$ & $0.8-20$ & $34-146$ & $10-61$ & $17-212$ & $5-320$ & $11-31$ \\
\hline $\begin{array}{l}\text { Manatee River near } \\
\text { Bradenton }\end{array}$ & $1962-66$ & $2.0-13$ & $0-12$ & $22-80$ & $6-140$ & $19-263$ & $5-220$ & $9-32$ \\
\hline $\begin{array}{l}\text { Little Manatee River } \\
\text { near Wimauma }\end{array}$ & $1956-76$ & 3. $2-22$ & $0.8-140$ & $21-323$ & $2-230$ & $37-668$ & $5-250$ & $13-31$ \\
\hline $\begin{array}{l}\text { Available standard } \\
\text { for potable water } \\
\text { U.S. Environmental } \\
\text { Protection Agency } \\
\text { (1976) }\end{array}$ & -- & 250 & 250 & 500 & -- & -- & 75 & --- \\
\hline
\end{tabular}




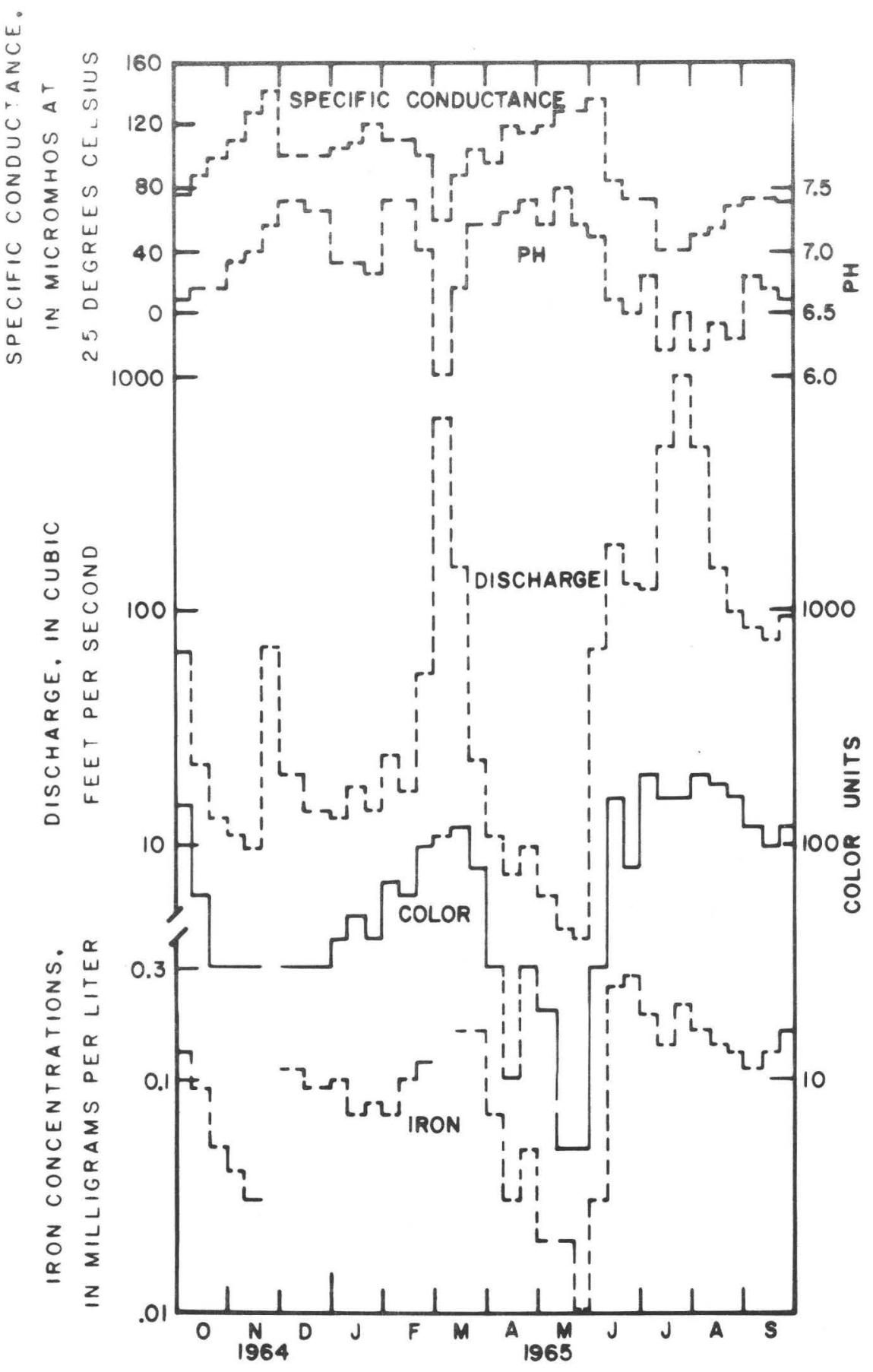

Figure 22.--Seasonal variations of discharge, color, iron, $\mathrm{pH}$, and specific conductance, Manatee River near Bradenton, October 1964 to September 1965 (modified from Kaufman, 1969). 
The dissolved mineral content of water from the surficial aquifer varies greatly. Water is generally of potable quality except near the coast and tidally affected streams where saltwater intrusion has taken place.

In northeastern Manatee County, the surficial aquifer is composed of relatively insoluble, quartz sand resulting in water that is low in mineral content and hardness (table 10 and fig. 23). Dissolved solids concentrations are usually less than $300 \mathrm{mg} / \mathrm{L}$. Concentrations of chloride and sulfate are also low, usually less than $10 \mathrm{mg} / \mathrm{L}$ and $5 \mathrm{mg} / \mathrm{L}$, respectively. Most water that is soft and low in mineral content has a relatively low $\mathrm{pH}$.

Near the coast and tidally affected streams, water in the surficial aquifer has concentrations of dissolved solids and chlorides of more than 200 and $50 \mathrm{mg} / \mathrm{L}$, respectively. Concentrations of sulfate vary considerably, but are usually less than $20 \mathrm{mg} / \mathrm{L}$. In many places along the coast, water in the surficial aquifer is highly mineralized, approaching that of seawater. In some lowlying and coastal areas, the surficial aquifer is highly mineralized because of infiltration or intrusion by seawater, leakage from improperly constructed wells, uncapped flowing wells, and irrigation water from wells that contain moderate to highly mineralized water (Joyner and Sutcliffe, 1976).

\section{Minor artesian aquifer}

The quality of water in the minor artesian aquifer is generally good except near the coast where saltwater intrusion has taken place or residual seawater has not been completely flushed from the aquifer. In northern and eastern Manatee County, concentrations of dissolved solids range from less than 200 to about $400 \mathrm{mg} / \mathrm{L}$ (fig. 24 and table 11). Concentrations of sulfate and chloride are less than 20 and $50 \mathrm{mg} / \mathrm{L}$, respectively.

In the central and northeastern parts of the county, the potentiometric surface of the minor artesian aquifer is lower than water levels of the surficial aquifer. Downward leakage of water from the surficial aquifer occurs, and the quality of water is similar to that of the surficial aquifer.

Near the coastal and southeastern parts of the county, the mineral content of water increases. Concentrations of dissolved solids range from about 500 to $1,000 \mathrm{mg} / \mathrm{L}$. Concentrations of sulfate range from less than 100 to about 500 $\mathrm{mg} / \mathrm{L}$. Concentrations of chloride are generally less than $250 \mathrm{mg} / \mathrm{L}$ except along the coast.

Near the coast, the potentiometric surface of the Floridan aquifer is higher than the potentiometric surface of the minor artesian aquifer, and upward leakage of moderate to highly mineralized water from the Floridan aquifer occurs. In some areas, water in the minor artesian aquifer is more mineralized than water from the Floridan aquifer. This is probably due to either (1) incomplete flushing of the system since the last recession of the sea during Pleistocene time, or (2) solution of mineral salts within the aquifer (Peek, 1958a). 
Table 10.--Quality of water from the surficial aquifer

[Concentrations are in milligrams per liter, except as indicated]

\begin{tabular}{|c|c|c|c|c|c|c|c|c|c|c|c|}
\hline $\begin{array}{l}\text { Site } \\
\text { num- } \\
\text { ber } \\
\text { (fig. } \\
23 \text { ) }\end{array}$ & We11 number & $\begin{array}{l}\text { Date of } \\
\text { collection }\end{array}$ & $\begin{array}{l}\text { Sampling } \\
\text { depth } \\
\text { (feet) }\end{array}$ & Silica & Iron & $\begin{array}{l}\text { Cal- } \\
\text { cium }\end{array}$ & $\begin{array}{l}\text { Magne- } \\
\text { sium }\end{array}$ & $\begin{array}{l}\text { Sod- } \\
\text { ium }\end{array}$ & $\begin{array}{l}\text { Potas- } \\
\text { sium }\end{array}$ & $\begin{array}{l}\text { Bicar- } \\
\text { bonate }\end{array}$ & $\begin{array}{l}\text { Sul- } \\
\text { fate }\end{array}$ \\
\hline $\begin{array}{l}1 \\
2 \\
3 \\
4 \\
5\end{array}$ & $\begin{array}{l}271134 \mathrm{~N} 0820922.2^{\mathrm{a}} \\
271456 \mathrm{~N} 0822309.2^{\mathrm{a}} \\
271821 \mathrm{~N} 0821551.1_{\mathrm{a}}^{\mathrm{b}} \\
271730 \mathrm{~N} 0820020.1^{\mathrm{a}} \\
271832 \mathrm{~N} 0820648.2^{\mathrm{a}}\end{array}$ & $\begin{array}{r}11 / 28 / 66 \\
11 / 29 / 66 \\
5 / 18 / 65 \\
10 / 14 / 75 \\
2 / 24 / 66\end{array}$ & $\begin{array}{l}20-25 \\
21-25 \\
17-22 \\
10-26 \\
65-70\end{array}$ & $\begin{array}{r}1.2 \\
15^{.7} \\
5.0 \\
14\end{array}$ & $\begin{array}{l}-- \\
-- \\
.32 \\
1.6 \\
.05\end{array}$ & $\begin{array}{l}6.3 \\
11 \\
47 \\
8 \\
83\end{array}$ & $\begin{array}{l}12 \\
4.4 \\
21 \\
3.4 \\
29\end{array}$ & $\begin{array}{l}63 \\
14 \\
5.6 \\
-- \\
16\end{array}$ & $\begin{array}{l}1.5 \\
20 \\
2.3 \\
-- \\
3.4\end{array}$ & $\begin{array}{r}116 \\
64 \\
221 \\
24 \\
180\end{array}$ & $\begin{array}{l}26 \\
0.0 \\
2.4 \\
<1 \\
162\end{array}$ \\
\hline $\begin{array}{r}8 \\
9 \\
10\end{array}$ & $\begin{array}{l}272048 \mathrm{~N} 0822858.02^{\mathrm{a}} \\
272356 \mathrm{~N} 0821813.01^{\mathrm{a}} \\
\quad(\text { test we11) } \\
2727340820524.01^{\mathrm{a}} \\
2727350820834.01 \\
2732030821032.01\end{array}$ & $\begin{array}{l}8 / 26 / 66 \\
3 / 15 / 65 \\
4 / 23 / 64 \\
8 / 30 / 65 \\
4 / 02 / 66\end{array}$ & $\begin{array}{c}35-38 \\
70-76 \\
15 \\
116-120 \\
20-35\end{array}$ & $\begin{array}{l}19 \\
16 \\
2.8 \\
26 \\
--\end{array}$ & $\begin{array}{l}.05 \\
-- \\
-- \\
-- \\
--\end{array}$ & $\begin{array}{l}64 \\
45 \\
50 \\
2.4\end{array}$ & ${ }_{--}^{20} .2$ & $\begin{array}{l}12 \\
2.6 \\
14 \\
--\end{array}$ & $\begin{array}{l}2.2 \\
0 \\
2.1 \\
--\end{array}$ & $\begin{array}{r}248 \\
3 \\
308 \\
-\end{array}$ & $\begin{array}{l}6.4 \\
0 \\
4.0 \\
.4\end{array}$ \\
\hline $\begin{array}{l}11 \\
12\end{array}$ & $\begin{array}{l}\text { Swift south shal- } \\
\text { low well } \\
\text { Swift north shal- }\end{array}$ & $6 / 09 / 75$ & $10-36$ & 4.3 & .31 & 3.2 & 1.0 & 6.1 & .19 & - & 2 \\
\hline $\begin{array}{l}13 \\
14 \\
15\end{array}$ & $\begin{array}{l}\text { 1ow we11 } \\
2736240821241.01^{a} \\
2735170820728.01^{a} \\
2740330820536.01^{a}\end{array}$ & $\begin{array}{l}6 / 09 / 75 \\
4 / 02 / 66 \\
3 / 31 / 66 \\
3 / 31 / 66\end{array}$ & $\begin{array}{c}10-36 \\
22-30 \\
10-22 \\
11\end{array}$ & $\begin{array}{l}6.2 \\
3.0 \\
-- \\
2.4\end{array}$ & $\begin{array}{l}.74 \\
-- \\
-- \\
--\end{array}$ & $\begin{array}{r}19 \\
.7 \\
3.9 \\
3.2\end{array}$ & $\begin{array}{c}5.3 \\
.6 \\
-- \\
1.3\end{array}$ & $\begin{array}{l}4.1 \\
2.8 \\
-- \\
2.7\end{array}$ & $\begin{array}{l}.62 \\
-- \\
3.1\end{array}$ & $\begin{array}{r}76 \\
2 \\
- \\
3\end{array}$ & $\begin{array}{l}3 \\
0 \\
-- \\
8.4\end{array}$ \\
\hline $\begin{array}{l}16 \\
17 \\
18 \\
19 \\
20\end{array}$ & $\begin{array}{l}2742130820848.01^{a} \\
2742280820348.01^{a} \\
2743170820402.01^{a} \\
2743360820336.01 \\
2744400821252.01^{a}\end{array}$ & $\begin{array}{l}3 / 31 / 66 \\
3 / 14 / 66 \\
3 / 14 / 66 \\
3 / 11 / 75 \\
3 / 12 / 70\end{array}$ & $\begin{array}{l}25-41 \\
30 \\
30 \\
\mathrm{SA}^{\mathrm{d}} \\
19\end{array}$ & $\begin{array}{l}11 \\
-- \\
-- \\
2.5 \\
--\end{array}$ & $\begin{array}{l}-- \\
-- \\
-- \\
-- \\
--\end{array}$ & $\begin{array}{l}6.6 \\
3.7 \\
2.0 \\
6 \\
--\end{array}$ & $\begin{array}{l}2.3 \\
-- \\
-- \\
1.5 \\
--\end{array}$ & $\begin{array}{l}4.3 \\
-- \\
-- \\
3.5 \\
--\end{array}$ & $\begin{array}{l}.3 \\
-- \\
-- \\
.8\end{array}$ & $\begin{array}{l}30 \\
- \\
- \\
11 \\
-\end{array}$ & $\begin{array}{l}.4 \\
-- \\
-- \\
--\end{array}$ \\
\hline $\begin{array}{l}21 \\
22 \\
23 \\
24\end{array}$ & $\begin{array}{l}2706030822502.01 \\
2707570822701.01 \\
2709040822817.01 \\
2708410822659.01\end{array}$ & $\begin{array}{l}7 / 13 / 65 \\
4 / 13 / 78 \\
4 / 26 / 78 \\
1 / 26 / 71\end{array}$ & $\begin{array}{l}46 \\
29 \\
42 \\
20\end{array}$ & $\begin{array}{l}22 \\
-- \\
-- \\
--\end{array}$ & $\begin{array}{r}160 \\
-- \\
-- \\
--\end{array}$ & $\begin{array}{r}96 \\
400 \\
150 \\
--\end{array}$ & $\begin{array}{l}7.4 \\
91 \\
26 \\
--\end{array}$ & $\begin{array}{l}23 \\
-- \\
-- \\
--\end{array}$ & $\begin{array}{l}1.5 \\
-- \\
-- \\
--\end{array}$ & $\begin{array}{c}312 \\
230 \\
360 \\
-\end{array}$ & $\begin{array}{r}15 \\
1,100 \\
180 \\
60\end{array}$ \\
\hline
\end{tabular}

Footnotes are at end of table. 
Table 10.--Quality of water from the surficial aquifer--Continued

\begin{tabular}{|c|c|c|c|c|c|c|c|c|c|c|c|c|}
\hline \multirow{2}{*}{$\begin{array}{l}\text { Site } \\
\text { num- } \\
\text { ber } \\
\text { (fig. } \\
23 \text { ) }\end{array}$} & \multirow{2}{*}{$\begin{array}{l}\text { Chlor- } \\
\text { ide }\end{array}$} & \multirow{2}{*}{$\begin{array}{l}\text { Fluor- } \\
\text { ide }\end{array}$} & \multirow{2}{*}{$\begin{array}{l}\mathrm{Ni}- \\
\text { trate }\end{array}$} & \multirow{2}{*}{$\begin{array}{l}\text { Phos- } \\
\text { phate }\end{array}$} & \multicolumn{2}{|c|}{$\begin{array}{l}\text { Dissolved } \\
\text { solids }\end{array}$} & \multicolumn{2}{|c|}{ Hardness } & \multirow{2}{*}{$\begin{array}{l}\text { Specific } \\
\text { conduc- } \\
\text { tance } \\
\text { (umho/cm } \\
\text { at } 25^{\circ} \mathrm{C} \text { ) }\end{array}$} & \multirow{2}{*}{$\begin{array}{c}\mathrm{pH} \\
\text { (units) }\end{array}$} & \multirow{2}{*}{$\begin{array}{l}\text { Color } \\
\text { (Pt-Co } \\
\text { units) }\end{array}$} & \multirow{2}{*}{$\begin{array}{l}\text { Tem- } \\
\text { pera- } \\
\text { ture } \\
\left({ }^{\circ} \mathrm{C}\right)\end{array}$} \\
\hline & & & & & $\begin{array}{l}\text { Calcu- } \\
\text { lated }\end{array}$ & $\begin{array}{c}\text { Residue } \\
\text { at } \\
180^{\circ} \mathrm{C}\end{array}$ & $\begin{array}{c}\text { Calcium- } \\
\text { magne- } \\
\text { sium }\end{array}$ & $\begin{array}{l}\text { Non- } \\
\text { carbo- } \\
\text { nate }\end{array}$ & & & & \\
\hline 1 & 52 & 1.9 & 0.2 & 0.06 & 221 & 208 & 65 & 0 & 410 & 7.9 & 5 & -- \\
\hline 2 & 31 & .1 & .4 & .02 & 96 & 84 & 46 & 0 & 238 & 7.1 & 10 & -- \\
\hline 3 & 8.0 & .9 & 0 & .70 & 212 & 220 & 204 & 23 & 370 & 8.0 & 5 & -- \\
\hline 4 & 11 & .3 & -- & 1.45 & - & 63 & 34 & -- & -- & 5.7 & 50 & -- \\
\hline 5 & 18 & 1.2 & 0 & .00 & 416 & 508 & 335 & 188 & 693 & 7.8 & 50 & -- \\
\hline 6 & 35 & .5 & .4 & 0 & 375 & 388 & 288 & 0 & 672 & 8.2 & 15 & -- \\
\hline 7 & 12 & .7 & .1 & -- & 236 & 252 & 196 & 0 & 400 & 7.9 & 10 & -- \\
\hline 8 & .5 & 0 & 0 & -- & 13 & 20 & 3 & 0 & 22 & 5.8 & 5 & -- \\
\hline 9 & 8.0 & .7 & 0 & .12 & 282 & -- & 228 & 0 & 475 & 8.1 & 5 & -- \\
\hline 10 & 4.5 & -- & -- & .2 & - & 17 & 4 & -- & 33 & - & -- & -- \\
\hline 11 & 9 & .2 & -- & -- & - & 24 & 12 & -- & 75 & - & 5 & -- \\
\hline 12 & 5 & .7 & -- & -- & - & 72 & 70 & -- & 134 & 6.4 & 5 & -- \\
\hline 13 & 5.2 & .1 & -- & 0 & 13 & -- & 4 & 3 & 32 & 5.2 & -- & -- \\
\hline 14 & 36 & .3 & 10 & .04 & 123 & -- & 32 & 28 & 242 & - & 0 & -- \\
\hline 15 & 7.0 & .2 & 6.4 & .07 & - & 35 & 14 & 11 & 62 & 5.2 & 0 & -- \\
\hline 16 & 6.0 & .7 & -- & 2.6 & 49 & -- & 26 & 2 & 75 & 6.6 & -- & -- \\
\hline 17 & -- & .1 & -- & .9 & - & 29 & -- & -- & 55 & - & -- & -- \\
\hline 18 & 7.0 & .2 & -- & .03 & - & 220 & -- & -- & 381 & - & -- & -- \\
\hline 19 & 5.1 & .1 & -- & -- & 39 & -- & 21 & -- & 64 & 6.4 & -- & -- \\
\hline 20 & 38 & -- & -- & -- & - & 190 & -- & -- & 341 & - & -- & -- \\
\hline 21 & 36 & .4 & 0 & 0 & 355 & -- & 270 & 14 & 609 & 7.7 & 5 & -- \\
\hline 22 & 54 & .3 & -- & -- & - & $-1,330$ & 1,400 & 1,200 & 2,150 & - & -- & -- \\
\hline 23 & 130 & .5 & -- & -- & - & 700 & 480 & 190 & 1,165 & - & -- & -- \\
\hline 24 & 80 & -- & -- & -- & - & 410 & 300 & -- & 700 & - & -- & 23 \\
\hline
\end{tabular}

Analysis by U.S. Geologica1 Survey.

bAnalysis by Geraghty and Miller, Inc. (1975).

cAnalysis by Swift Chemical.

$\mathrm{d}_{\text {Surficial aquifer. }}$ 


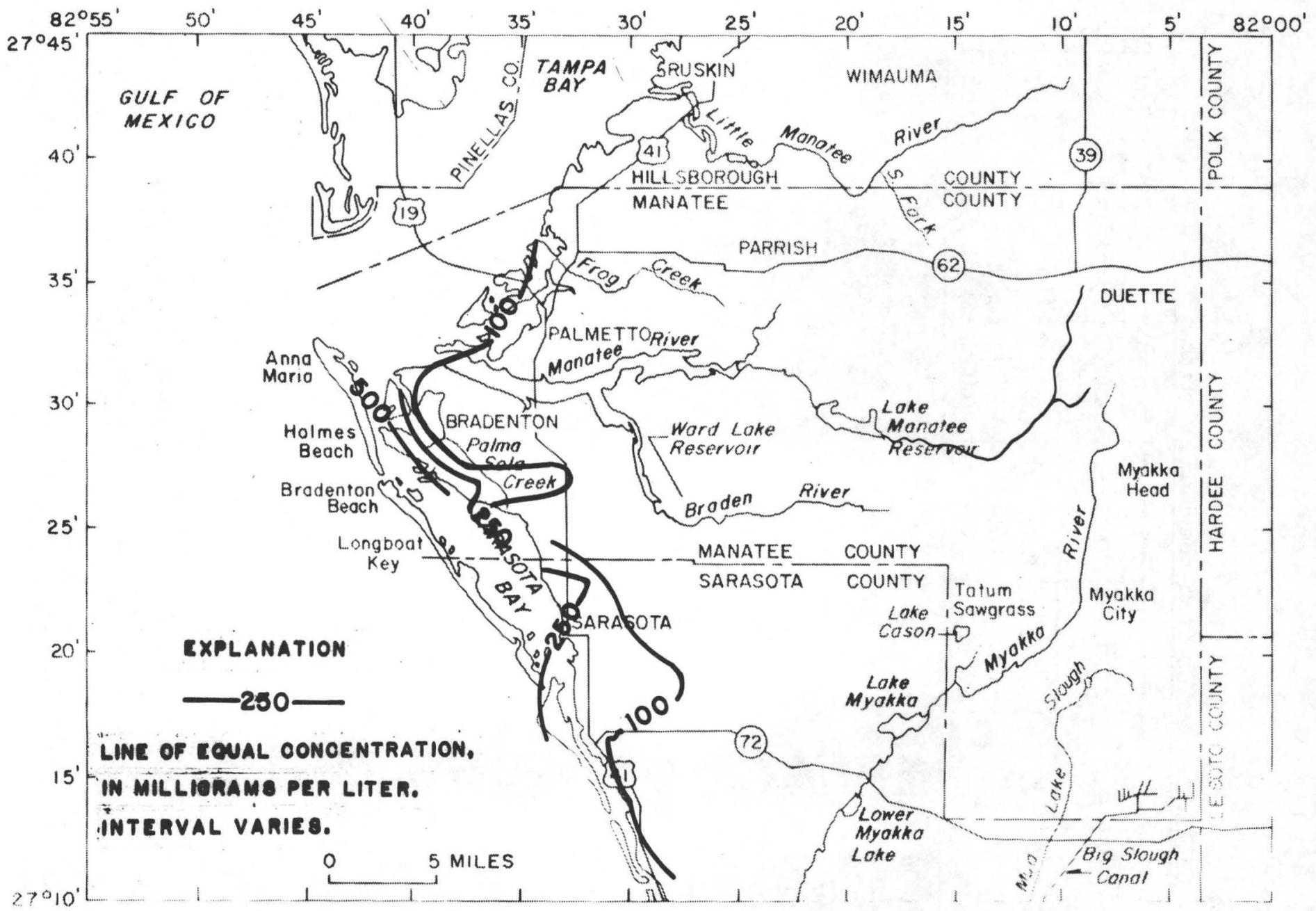

Figure 24a.--Concentrations of chloride in water from the minor artesian aquifer. 


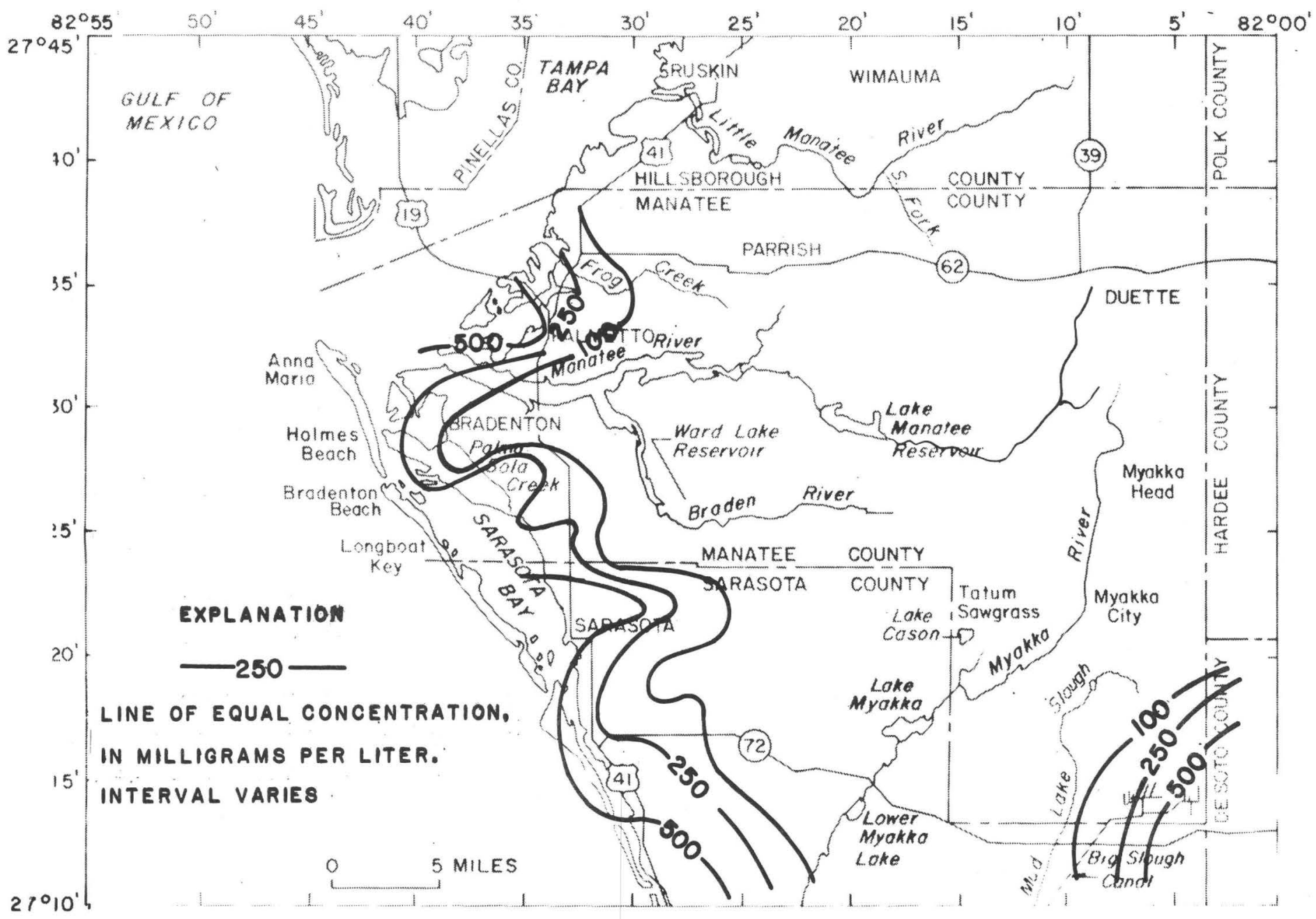

Figure 24b.--Concentrations of sulfate in water from the minor artesian aquifer. 


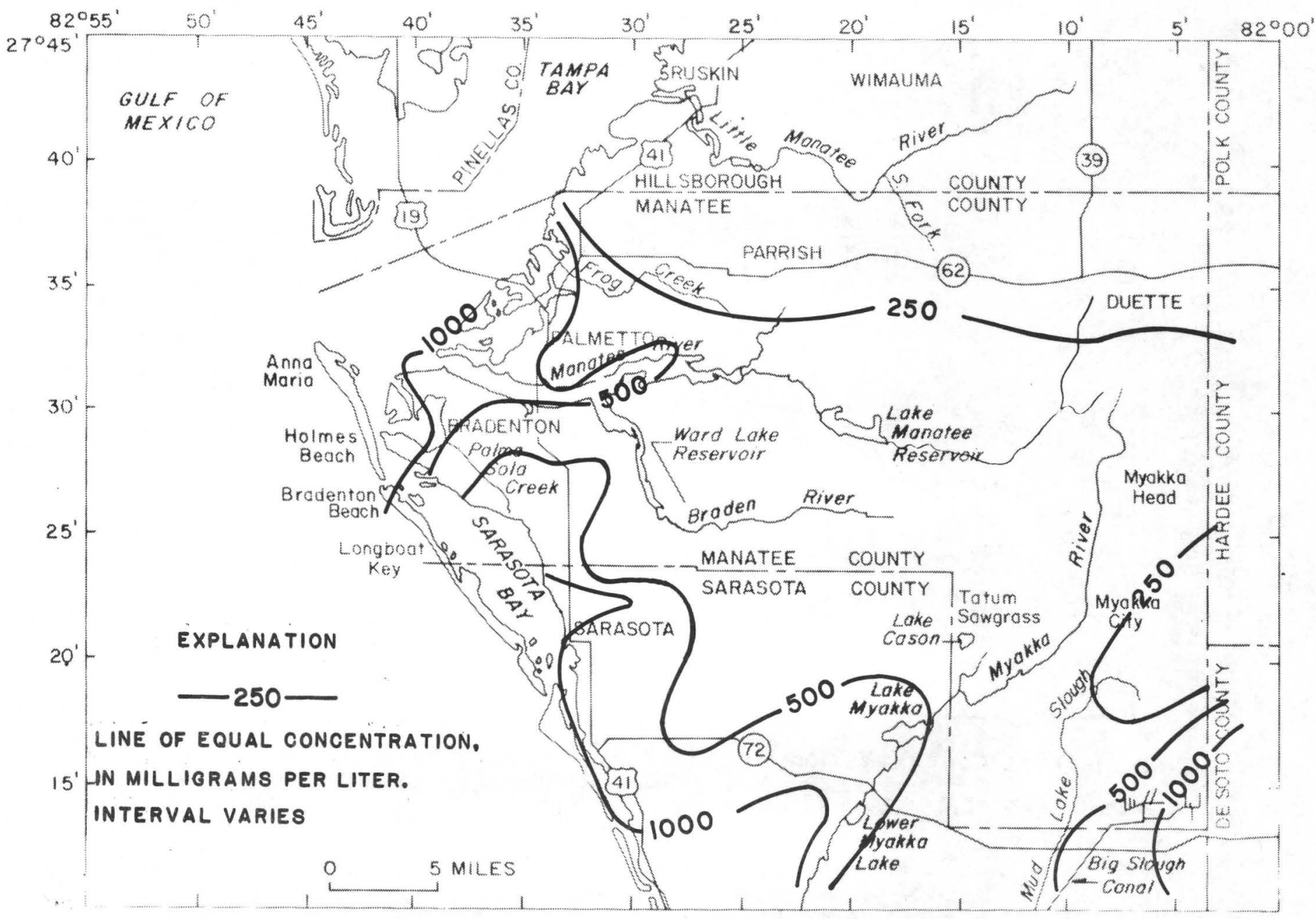

Figure 24c.--Concentrations of dissolved solids in water from the minor artesian aquifer. 
Table 11.--Quality of water from the minor artesian aquifer

[Concentrations are in milligrams per liter, except as indicated]

\begin{tabular}{|c|c|c|c|c|c|c|c|c|c|c|c|}
\hline We11 number & $\begin{array}{l}\text { Date of } \\
\text { collection }\end{array}$ & $\begin{array}{c}\text { Sampling } \\
\text { depth } \\
\text { (feet) }\end{array}$ & Silica & Iron & $\begin{array}{l}\text { Cal- } \\
\text { cium }\end{array}$ & $\begin{array}{l}\text { Magne- } \\
\text { sium }\end{array}$ & Sodium & $\begin{array}{l}\text { Potas- } \\
\text { sium }\end{array}$ & $\begin{array}{l}\text { Bicar- } \\
\text { bonate }\end{array}$ & $\begin{array}{l}\text { Sul- } \\
\text { fate }\end{array}$ & $\begin{array}{l}\text { Chlor- } \\
\text { ide }\end{array}$ \\
\hline 2709070822616.01 & $4 / 20 / 71$ & $63-89$ & -- & -- & - & - & -- & - & -- & 140 & 80 \\
\hline 2710420822953.01 & $7 / 07 / 66$ & 110 & - & -- & - & - & -- & - & -- & 325 & 158 \\
\hline $2712300820530.01^{a}$ & $11 / 07 / 74$ & $60-300$ & 24 & 0.4 & 184 & 60 & -- & - & 186 & 530 & 58 \\
\hline 2713080823057.01 & $9 / 12 / 63$ & 148 & - & -- & - & - & -- & - & -- & 483 & 186 \\
\hline 2713130820817.01 & $12 / 13 / 63$ & $43-256$ & 33 & -- & 70 & 39 & 20 & 1.8 & 246 & 134 & 28 \\
\hline $2714570820322.02^{b}$ & $2 / 21 / 75$ & 300 & 4.6 & .89 & 256 & 10 & -- & - & 26 & 651 & 34 \\
\hline 2715320823017.01 & $2 / 11 / 65$ & $60-263$ & -- & .03 & - & - & -- & - & -- & 406 & 50 \\
\hline 2715340822401.01 & $2 / 15 / 68$ & $82-290$ & -- & -- & - & - & -- & - & -- & 88 & 86 \\
\hline 2715520823004.01 & $11 / 12 / 64$ & 100 & -- & -- & - & - & -- & - & -- & 68 & 100 \\
\hline 2716080822802.01 & $4 / 21 / 66$ & $58-102$ & -- & - & - & - & -- & - & -- & 346 & 68 \\
\hline 2716080823108.01 & $11 / 12 / 64$ & $61-150$ & -- & - & - & - & -- & - & -- & 158 & 185 \\
\hline 2716370823338.01 & $3 / 24 / 64$ & 180 & -- & -- & - & - & -- & - & -- & 510 & 240 \\
\hline 2716480822637.01 & $12 / 18 / 66$ & $134-180$ & -- & .1 & - & - & -- & - & - & 7.6 & 74 \\
\hline 2717280822742.01 & $11 / 08 / 72$ & $107-152^{-}$ & - & $<.01$ & - & - & -- & - & -- & 120 & 100 \\
\hline 2717360823319.01 & $10 / 10 / 63$ & $71-150$ & -- & -- & - & - & -- & - & -- & 289 & 125 \\
\hline 2717520821606.01 & 4/11/62 & 150 & -- & -- & - & - & -- & - & - & 193 & 38 \\
\hline 2717530822723.01 & $11 / 08 / 72$ & $76-106$ & -- & .01 & - & - & -- & - & - & 80 & 80 \\
\hline 2717570822413.01 & $8 /--/ 66$ & $67-120$ & -- & - & - & - & -- & - & -- & 418 & 78 \\
\hline 2718300822814.01 & $11 / 13 / 64$ & $82-100$ & -- & -- & - & - & -- & - & -- & 38 & 122 \\
\hline 2719380821748.01 & $7 / 11 / 63$ & 120 & -- & -- & - & - & -- & - & -- & 58 & 72 \\
\hline 2719420822842.01 & $9 / 21 / 64$ & $53-91$ & -- & -- & - & - & -- & - & -- & 145 & 87 \\
\hline 2720100822705.01 & $2 / 15 / 73$ & 245 & -- & $<.01$ & - & - & -- & - & -- & 150 & 60 \\
\hline 2721030823235.01 & $10 / 10 / 62$ & $60-230$ & - & -- & - & - & -- & - & -- & 536 & 269 \\
\hline 2721060823105.01 & $4 / 21 / 64$ & $94-170$ & -- & -- & - & - & -- & - & -- & 54 & 116 \\
\hline 2721260822929.01 & $5 / 16 / 62$ & $55-150$ & -- & -- & - & - & -- & - & -- & 560 & 85 \\
\hline
\end{tabular}

Footnotes are at end of table. 
Table 11.--Quality of water from the minor artesian aquifer--Continued

\begin{tabular}{|c|c|c|c|c|c|c|c|c|c|c|c|}
\hline We11 number & $\begin{array}{l}\text { Date of } \\
\text { collection }\end{array}$ & $\begin{array}{c}\text { Sampling } \\
\text { depth } \\
\text { (feet) }\end{array}$ & Silica & Iron & $\begin{array}{l}\text { Cal- } \\
\text { cium }\end{array}$ & $\begin{array}{l}\text { Magne- } \\
\text { sium }\end{array}$ & Sodium & $\begin{array}{l}\text { Potas- } \\
\text { sium }\end{array}$ & $\begin{array}{l}\text { Bicar- } \\
\text { bonate }\end{array}$ & $\begin{array}{l}\text { Sul- } \\
\text { fate }\end{array}$ & $\begin{array}{l}\text { Chlor- } \\
\text { ide }\end{array}$ \\
\hline 2721260823230.02 & $10 / 21 / 62$ & 145 & -- & -- & - & - & -- & - & -- & 53 & 122 \\
\hline 2721420823718.01 & $9 / 30 / 66$ & $168-213$ & -- & -- & - & - & -- & - & -- & 160 & 460 \\
\hline 2722030823221.01 & $1 / 27 / 72$ & 51-199 & -- & .6 & - & - & -- & - & -- & 825 & 1,200 \\
\hline 2722550823039.01 & $11 / 12 / 64$ & $47-173$ & -- & -- & - & - & -- & - & .2 & 10 & -- \\
\hline 2725050823314.01 & $10 / 28 / 71$ & $33-87$ & -- & .2 & - & - & -- & - & 225 & 84 & -- \\
\hline 2725450824104.01 & $6 / 07 / 67$ & $45-228$ & -- & -- & - & - & -- & - & -- & -- & -- \\
\hline \multirow[t]{2}{*}{2727330820532.01} & $6 / 03 / 64$ & $80-280$ & 51 & -- & 44 & 25 & 17 & 2.1 & 270 & 16 & 11 \\
\hline & $3 / 31 / 66$ & & 52 & -- & 42 & 25 & 19 & 2.1 & 268 & 15 & 9.0 \\
\hline 2727410824146.02 & $6 / 10 / 76$ & 350 & 25 & 1.1 & 230 & 110 & 160 & 9.6 & 179 & 670 & 410 \\
\hline 2727460824009.01 & $7 / 21 / 64$ & $147-163$ & -- & -- & - & - & -- & - & -- & 194 & 570 \\
\hline 2727510823703.01 & $3 / 12 / 68$ & $290-350$ & -- & -- & - & - & -- & - & -- & 450 & 360 \\
\hline $2730020820816.01^{c}$ & 74 & $130-200$ & 32 & 7.8 & 68 & 36 & 28 & 8.0 & 182 & 76 & 17 \\
\hline \multirow[t]{2}{*}{2731180823842.01} & $2 / 18 / 55$ & $23-100$ & -- & -- & 104 & 56 & -- & - & 220 & 240 & 96 \\
\hline & $9 / 27 / 65$ & & 31 & -- & 96 & 50 & 44 & 4.2 & 226 & 294 & 100 \\
\hline 2732150821027.01 & $4 / 02 / 66$ & $65-105$ & 27 & .01 & 49 & 24 & 10 & .3 & 288 & 0.0 & 4.0 \\
\hline $2732540820728.01^{\mathrm{d}}$ & $6 / 09 / 75$ & $120-249$ & 56 & .13 & 50 & 15 & -- & - & -- & 34 & 12 \\
\hline 2735030823657.01 & $9 / 19 / 75$ & 330 & -- & -- & 150 & 79 & -- & - & 300 & 240 & - \\
\hline 2736490821237.01 & $4 / 01 / 66$ & $80-350$ & 41 & -- & 32 & 16 & 5.1 & 1.7 & 184 & .4 & 3.0 \\
\hline \multirow[t]{3}{*}{2737220823158.01} & $5 / 10 / 66$ & $35-98$ & 1.2 & -- & 86 & 26 & 35 & 6.0 & 241 & 106 & 70 \\
\hline & $4 / 28 / 67$ & & 28 & -- & 74 & 27 & 38 & 6.9 & 244 & 69 & 75 \\
\hline & $9 / 08 / 67$ & & 27 & -- & 78 & 25 & 39 & 6.8 & 248 & 90 & 72 \\
\hline 2737230823211.01 & $5 / 10 / 66$ & $170-284$ & - & -- & - & - & - & - & - & 202 & 44 \\
\hline
\end{tabular}


Table 11.--Quality of water from the minor artesian aquifer--Continued

\begin{tabular}{|c|c|c|c|c|c|c|c|c|c|c|c|}
\hline \multirow{2}{*}{ We11 number } & \multirow{2}{*}{$\begin{array}{l}\text { Fluor- } \\
\text { ide }\end{array}$} & \multirow{2}{*}{$\begin{array}{l}\mathrm{Ni}- \\
\text { trate }\end{array}$} & \multirow{2}{*}{$\begin{array}{l}\text { Phos- } \\
\text { phate }\end{array}$} & \multicolumn{2}{|c|}{$\begin{array}{l}\text { Dissolved } \\
\text { solids }\end{array}$} & \multicolumn{2}{|c|}{ Hardness } & \multirow{2}{*}{$\begin{array}{l}\text { Specific } \\
\text { conduc- } \\
\text { tance } \\
\text { (umho/cm } \\
\text { at } 25^{\circ} \mathrm{C} \text { ) }\end{array}$} & \multirow{2}{*}{$\begin{array}{c}\mathrm{pH} \\
\text { (units) }\end{array}$} & \multirow{2}{*}{$\begin{array}{l}\text { Color } \\
\text { (Pt-Co } \\
\text { units) }\end{array}$} & \multirow{2}{*}{$\begin{array}{l}\text { Tem- } \\
\text { pera- } \\
\text { ture } \\
\left({ }^{O} \mathrm{C}\right)\end{array}$} \\
\hline & & & & $\begin{array}{l}\text { Calcu- } \\
\text { lated }\end{array}$ & $\begin{array}{c}\text { Residue } \\
\text { at } \\
180^{\circ} \mathrm{C}\end{array}$ & $\begin{array}{l}\text { Calcium- } \\
\text { magne- } \\
\text { sium }\end{array}$ & $\begin{array}{l}\text { Non- } \\
\text { carbo- } \\
\text { nate }\end{array}$ & & & & \\
\hline 2709070822616.01 & - & -- & -- & -- & 480 & 225 & - & 750 & - & -- & 26.0 \\
\hline 2710420822953.01 & - & -- & -- & -- & -- & -- & - & -- & - & -- & 28.9 \\
\hline $2712300820530.01^{a}$ & 1.9 & 0.28 & 0.84 & -- & 998 & 706 & 520 & 1,000 & 7.4 & -- & 24.2 \\
\hline 2713080823057.01 & - & -- & -- & -- & 1,000 & 741 & - & 1,580 & - & -- & -- \\
\hline 2713130820817.01 & 2.1 & 0.0 & .06 & 449 & 482 & 336 & 134 & 690 & 8.0 & 5 & 24.4 \\
\hline $2714570820322.02^{b}$ & .91 & .72 & - & -- & 1,179 & 683 & 655 & 1,300 & 7.9 & -- & 26.5 \\
\hline 2715320823017.01 & - & - & -- & -- & 680 & 560 & - & 1,150 & - & -- & 25 \\
\hline 2715340822401.01 & - & - & -- & -- & 580 & 354 & - & 910 & - & -- & -- \\
\hline 2715520823004.01 & - & - & - & -- & 520 & 320 & - & 810 & - & -- & 24.4 \\
\hline 2716080822802.01 & - & - & -- & -- & 800 & 608 & - & 1,230 & - & -- & 26.1 \\
\hline 2716080823108.01 & - & - & -- & -- & 800 & 480 & - & 1,230 & - & -- & 23.9 \\
\hline 2716370823338.01 & - & - & -- & -- & 1,130 & 525 & - & 1,800 & - & -- & -- \\
\hline 2716480822637.01 & - & - & -- & -- & 440 & -- & - & 682 & - & -- & -- \\
\hline 2717280822742.01 & - & - & -- & -- & 480 & 400 & - & 740 & - & -- & -- \\
\hline 2717360823319.01 & - & - & -- & -- & 700 & 530 & - & 1,100 & - & -- & -- \\
\hline 2717520821606.01 & - & - & -- & -- & 500 & 418 & - & 678 & - & -- & 23.9 \\
\hline 2717530822723.01 & - & - & -- & -- & 420 & 400 & - & 650 & - & -- & -- \\
\hline 2717570822413.01 & - & - & -- & -- & 860 & 626 & - & 1,310 & - & -- & 26.1 \\
\hline 2718300822814.01 & - & - & -- & -- & 560 & 264 & - & 779 & - & -- & 24.4 \\
\hline 2719380821748.01 & - & - & -- & -- & 440 & 306 & - & 730 & - & -- & -- \\
\hline 2719420822842.01 & - & - & -- & -- & 550 & 386 & - & 845 & - & -- & 24.4 \\
\hline 2720100822705.01 & - & - & -- & -- & 500 & 300 & - & 675 & - & -- & -- \\
\hline 2721030823235.01 & - & - & -- & -- & 1,300 & -- & - & 1,980 & - & -- & -- \\
\hline 2721060823105.01 & - & - & -- & -- & 550 & -- & - & 860 & - & -- & 24.4 \\
\hline 2721260822929.01 & - & - & -- & -- & 1,000 & 840 & - & 1,550 & - & -- & 25.0 \\
\hline
\end{tabular}


Table 11.--Quality of water from the minor artesian aquifer--Continued

\begin{tabular}{|c|c|c|c|c|c|c|c|c|c|c|c|}
\hline \multirow[b]{2}{*}{ We11 number } & \multirow{2}{*}{$\begin{array}{l}\text { F1uor- } \\
\text { ide }\end{array}$} & \multirow{2}{*}{$\begin{array}{l}\mathrm{Ni}- \\
\text { trate }\end{array}$} & \multirow{2}{*}{$\begin{array}{l}\text { Phos- } \\
\text { phate }\end{array}$} & \multicolumn{2}{|c|}{$\begin{array}{l}\text { Dissolved } \\
\text { solids }\end{array}$} & \multicolumn{2}{|c|}{ Hardness } & \multirow{2}{*}{$\begin{array}{l}\text { Specific } \\
\text { conduc- } \\
\text { tance } \\
\text { (umho/cm } \\
\text { at } 25^{\circ} \mathrm{C} \text { ) }\end{array}$} & \multirow{2}{*}{$\begin{array}{c}\mathrm{pH} \\
\text { (units) }\end{array}$} & \multirow{2}{*}{$\begin{array}{l}\text { Color } \\
\text { (Pt-Co } \\
\text { units) }\end{array}$} & \multirow{2}{*}{$\begin{array}{l}\text { Tem- } \\
\text { pera- } \\
\text { ture } \\
\left({ }^{0} \mathrm{C}\right)\end{array}$} \\
\hline & & & & $\begin{array}{l}\text { Calcu- } \\
\text { lated }\end{array}$ & $\begin{array}{c}\text { Residue } \\
\text { at } \\
180^{\circ} \mathrm{C}\end{array}$ & $\begin{array}{l}\text { Calcium- } \\
\text { magne- } \\
\text { sium }\end{array}$ & $\begin{array}{l}\text { Non- } \\
\text { carbo- } \\
\text { nate }\end{array}$ & & & & \\
\hline 2721260823230.02 & - & - & -- & -- & -- & 92 & - & -- & - & -- & -- \\
\hline 2721420823718.01 & - & - & -- & -- & 1,320 & -- & - & 2,070 & - & -- & -- \\
\hline 2722030823221.01 & - & - & -- & -- & 4,150 & 1,950 & - & 6,500 & - & -- & -- \\
\hline 2722550823039.01 & - & - & -- & -- & 350 & 294 & - & 553 & - & -- & -- \\
\hline 2725050823314.01 & - & - & -- & -- & 800 & 530 & - & 1,250 & - & -- & 23.5 \\
\hline 2725450824104.01 & - & - & -- & -- & 520 & -- & - & 800 & - & -- & 26.1 \\
\hline \multirow[t]{2}{*}{2727330820532.01} & 2.9 & 0.00 & 0.0 & 302 & 298 & 213 & 0 & 435 & 8.0 & 5 & -- \\
\hline & .3 & .00 & .1 & 296 & -- & 208 & 0 & 435 & 8.0 & 0 & -- \\
\hline 2727410824146.02 & 1.7 & - & -- & 1,720 & 1,870 & 1,100 & 900 & 2,700 & 7.4 & 0 & 26.5 \\
\hline 2727460824009.01 & 1.6 & - & -- & -- & 1,450 & -- & - & 2,300 & - & -- & 23.8 \\
\hline $2727510823703.01 \mathrm{c}$ & - & - & -- & -- & 1,400 & -- & - & 2,150 & - & -- & 26 \\
\hline $2730020820816.01^{c}$ & 1.6 & .01 & 4.0 & 398 & 399 & 318 & 116 & 420 & 8.5 & -- & -- \\
\hline \multirow[t]{2}{*}{2731180823842.01} & - & - & -- & -- & 750 & 490 & 310 & 1,040 & 7.4 & -- & 23.8 \\
\hline & .5 & 0.0 & -- & 731 & -- & 445 & 260 & 1,100 & 7.5 & 15 & 23.3 \\
\hline 2732150821027.01 & .2 & .20 & $<.01$ & 257 & -- & 220 & 0 & 420 & 8.0 & 10 & -- \\
\hline $2732540820728.01^{d}$ & - & .49 & -- & -- & 290 & 186 & 2.0 & 390 & 7.7 & 5 & -- \\
\hline 2735030823657.01 & - & - & -- & -- & -- & 700 & - & 1,650 & - & -- & 25.6 \\
\hline 2736490821237.01 & .2 & - & .35 & -- & 170 & -- & - & 267 & 7.5 & -- & 24.4 \\
\hline \multirow[t]{3}{*}{2737220823158.01} & .6 & 0.00 & .26 & 451 & 564 & 320 & 130 & 780 & 7.8 & 5 & 27.7 \\
\hline & .7 & .20 & -- & 441 & 450 & 300 & 98 & 800 & 7.9 & 5 & -- \\
\hline & 1.1 & .10 & .02 & 463 & 486 & 300 & 96 & 725 & 7.7 & 10 & -- \\
\hline 2737230823211.01 & - & - & -- & -- & 500 & 370 & - & 810 & - & -- & 26.7 \\
\hline
\end{tabular}


Fluoride concentrations in water from wells penetrating the Hawthorn Formation range from less than 0.5 to about $3.0 \mathrm{mg} / \mathrm{L}$. The source of the fluoride is apparently associated with the phosphate minerals within the formation (Toler, 1967).

Floridan aquifer

Water in the Floridan aquifer is generally more mineralized than water from the surficial and minor artesian aquifers. Mineral content of the water within the aquifer varies vertically and areally. Mineral content of the water generally increases with depth of the aquifer penetrated. Water from wells open to the upper water-bearing zone is generally less mineralized than water from wells open to the middle water-bearing zone. Water from wells open to the lower waterbearing zone or to the full thickness of the aquifer has the highest mineralization.

Dissolved Solids.--Concentrations of dissolved solids in water from the Floridan aquifer range from about 300 to more than 2,500 $\mathrm{mg} / \mathrm{L}$ in the three major water-bearing zones. Concentrations generally increase with depth and 1aterally from the northeastern part of the county towards the west and south. Dissolved solids in water from wells penetrating the upper zone exceed $500 \mathrm{mg} / \mathrm{L}$ in the western and southern parts of the county (fig. 25 and table 12).

Water from wells penetrating the middle zone has dissolved solids concentrations ranging from about 300 to $1,800 \mathrm{mg} / \mathrm{L}$ (fig. 25 and table 13). In northeastern Manatee County, dissolved solids are less than $500 \mathrm{mg} / \mathrm{L}$, and in the western and southeastern parts of the county, dissolved solids concentrations range from about 600 to $1,500 \mathrm{mg} / \mathrm{L}$. Dissolved solids concentrations in a sma11 area west of Myakka City near the Verna well field exceed 1,000 mg/L.

Concentrations of dissolved solids in water from wells penetrating the lower zone range from about 300 to $2,500 \mathrm{mg} / \mathrm{L}$ (table 14 and fig. 25). In the northeastern part of the county, dissolved solids concentrations are generally less than $400 \mathrm{mg} / \mathrm{L}$, and in the western and coastal parts, dissolved solids exceed 1,000 and $2,000 \mathrm{mg} / \mathrm{L}$, respectively. Concentrations exceeding $1,000 \mathrm{mg} / \mathrm{L}$ of dissolved solids occur east of Parrish and northwest of Myakka City (fig. 25).

Chloride.--Concentrations of chloride in water from the Floridan aquifer are less than $250 \mathrm{mg} / \mathrm{L}$ except near the coast where the aquifer contains connate water (fig. 26 and table 15). In eastern and southeastern Manatee County, concentrations of chloride are generally less than $50 \mathrm{mg} / \mathrm{L}$ and change little with depth.

Concentrations of chloride in the western and coastal areas open to the upper zone range from less than 50 to more than $700 \mathrm{mg} / \mathrm{L}$, generally increasing seaward and with depth (fig. 26). Concentrations of chloride in water from wells open to the middle zone usually exceed $250 \mathrm{mg} / \mathrm{L}$ in the coastal areas (fig. 26). In water from wells open to the upper part of the lower zone, concentrations exceed $500 \mathrm{mg} / \mathrm{L}$ in coastal areas ( $\mathrm{fig} .26$ ). 


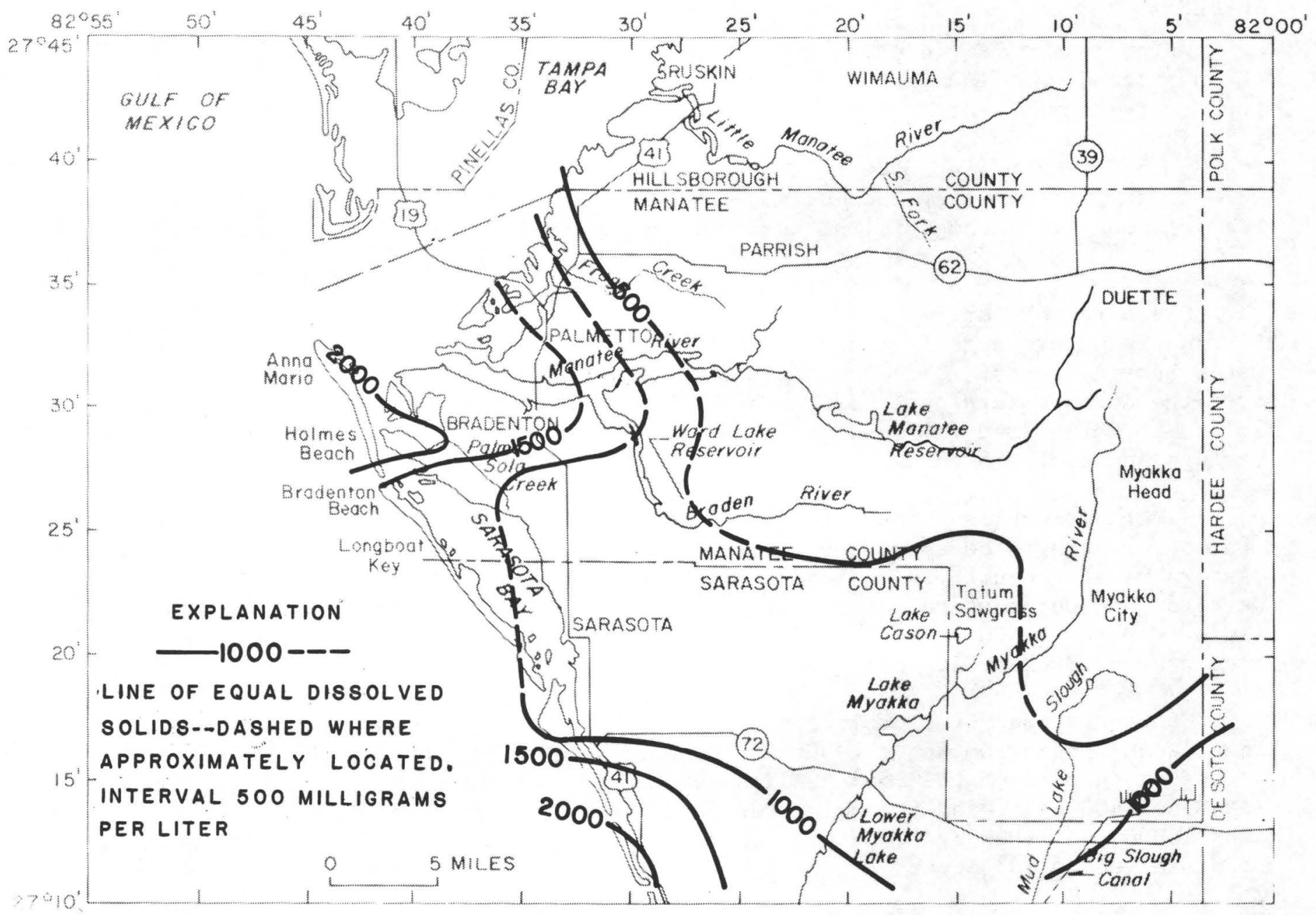

Figure 25a.--Concentrations of dissolved solids in water from the Tampa (upper zone) Limestone. 


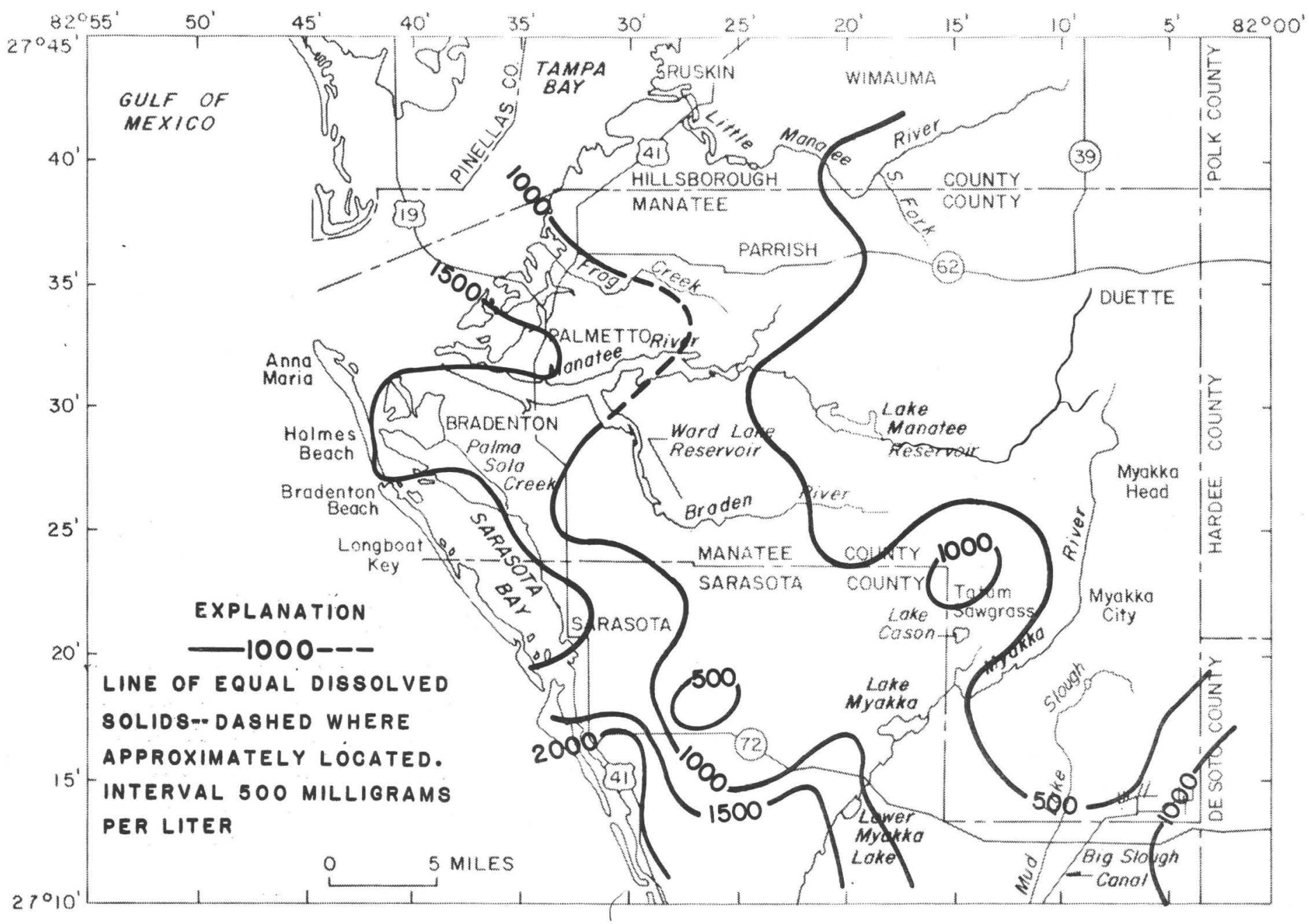

Figure 25b.--Concentrations of dissolved solids in water from the Suwannee-0cala (middle zone) Limestones. 


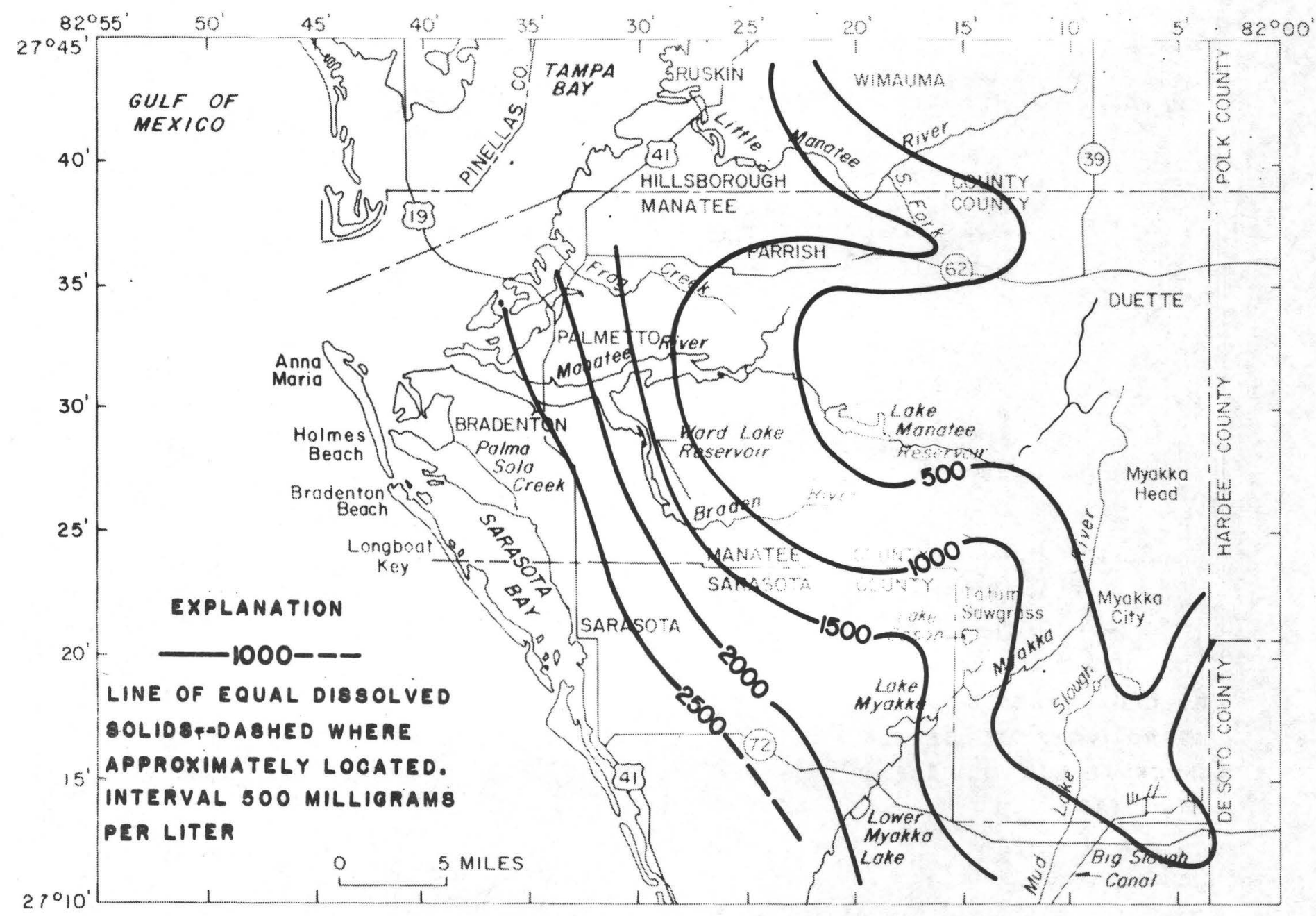

Figure 25c.--Concentrations of dissolved solids in water from the Avon Park (lower zone) Limestone. 
Table 12.--Quality of water from the Tampa Limestone (upper water-bearing zone)

[Concentrations are in milligrams per liter, except as indicated]

\begin{tabular}{|c|c|c|c|c|c|c|c|c|c|c|c|}
\hline We11 number & $\begin{array}{l}\text { Date of } \\
\text { collection }\end{array}$ & $\begin{array}{l}\text { Sampling } \\
\text { depth } \\
\text { (feet) }\end{array}$ & Silica & Iron & $\begin{array}{l}\text { Cal- } \\
\text { cium }\end{array}$ & $\begin{array}{l}\text { Magne- } \\
\text { sium }\end{array}$ & Sodium & $\begin{array}{l}\text { Potas- } \\
\text { sium }\end{array}$ & $\begin{array}{l}\text { Bicar- } \\
\text { bonate }\end{array}$ & $\begin{array}{l}\text { Sul- } \\
\text { fate }\end{array}$ & $\begin{array}{l}\text { Chlor- } \\
\text { ide }\end{array}$ \\
\hline 2707140821552.01 & $3 / 30 / 66$ & $282-350$ & 25 & 60 & 141 & 87 & 71 & 4.4 & 176 & 506 & 142 \\
\hline 2710370822748.01 & $1 / 26 / 68$ & $28-424$ & - & - & - & - & - & - & - & 1,750 & 300 \\
\hline 2711180822853.01 & $8 / 25 / 66$ & $154-255$ & 26 & 20 & 450 & 158 & 59 & 6.2 & 168 & 1,540 & 110 \\
\hline 2715230823213.01 & $7 / 16 / 62$ & $138-412$ & - & - & - & - & - & - & - & 1,140 & 175 \\
\hline 2716110822348.01 & $1 / 23 / 68$ & $122-349$ & - & - & - & - & - & - & - & 29 & 146 \\
\hline 2716190822402.01 & $12 / 07 / 67$ & $104-446$ & - & - & - & - & - & - & - & 440 & 60 \\
\hline 2716540823311.01 & $5 / 25 / 71$ & 415 & - & 20 & - & - & - & - & - & 500 & 75 \\
\hline 2717040823319.01 & $4 / 04 / 73$ & 406 & - & 0 & - & - & - & - & - & 357 & 63 \\
\hline 2718320820648.01 & $6 / 24 / 65$ & $416-485$ & 25 & 0 & 82 & 42 & 19 & 3.4 & 228 & 191 & 20 \\
\hline 2720190823226.01 & $3 / 15 / 72$ & 346 & 750 & - & - & - & - & - & - & 330 & 170 \\
\hline $\begin{array}{l}2722480821846.01 \\
\quad(P-5)\end{array}$ & $4 / 28 / 75$ & 383 & - & - & 130 & 60 & - & - & 119 & 370 & 18 \\
\hline 2723070821645.01 & $6 / 23 / 70$ & 404 & 26 & - & 139 & 68 & 14 & 2.7 & 1.94 & 450 & 18 \\
\hline & $4 / 30 / 75$ & - & - & - & 140 & 62 & - & - & 190 & 420 & 16 \\
\hline 2723240823831.01 & $6 / 10 / 76$ & 417 & 27 & 140 & 210 & 96 & 140 & 9.0 & 163 & 660 & 320 \\
\hline 2723560821813.01 & $4 / 09 / 65$ & $309-350$ & 28 & 20 & 40 & 30 & 23 & 4.4 & 298 & 2.4 & 13 \\
\hline 2724170823909.01 & $11 / 03 / 72$ & 433 & - & 100 & - & - & - & - & - & 260 & 220 \\
\hline 2725580823606.01 & $10 / 11 / 72$ & 399 & - & 10 & - & - & - & - & - & 120 & 60 \\
\hline 2727350820834.01 & $9 / 22 / 65$ & $227-400$ & - & - & 31 & 26 & - & - & - & 0 & 28 \\
\hline 2727400823730.01 & $6 / 11 / 76$ & $134-410$ & 35 & 10 & 160 & 53 & 120 & 4.2 & 281 & 220 & 290 \\
\hline 2727500823803.01 & $6 / 11 / 76$ & 360 & 25 & 300 & 290 & 120 & 310 & 5.8 & 161 & 730 & 770 \\
\hline 2731310824303.01 & $6 / 10 / 76$ & 402 & 28 & 90 & 220 & 100 & 220 & 9.6 & 191 & 450 & 630 \\
\hline 2733330823329.01 & $3 / 09 / 71$ & 403 & - & - & - & - & - & - & - & 600 & 190 \\
\hline
\end{tabular}


Table 12.--Quality of water from the Tampa Limestone (upper water-bearing zone)--Continued

\begin{tabular}{|c|c|c|c|c|c|c|c|c|c|c|c|}
\hline \multirow{2}{*}{ We11 number } & \multirow{2}{*}{$\begin{array}{l}\text { Fluor- } \\
\text { ide }\end{array}$} & \multirow{2}{*}{$\begin{array}{l}\mathrm{Ni}- \\
\text { trate }\end{array}$} & \multirow{2}{*}{$\begin{array}{l}\text { Phos- } \\
\text { phate }\end{array}$} & \multicolumn{2}{|c|}{$\begin{array}{l}\text { Dissolved } \\
\text { solids }\end{array}$} & \multicolumn{2}{|c|}{ Hardness } & \multirow{2}{*}{$\begin{array}{l}\text { Specific } \\
\text { conduc- } \\
\text { tance } \\
\text { (umho } / \mathrm{cm} \\
\text { at } 25^{\circ} \mathrm{C} \text { ) }\end{array}$} & \multirow{2}{*}{$\begin{array}{c}\mathrm{pH} \\
\text { (units) }\end{array}$} & \multirow{2}{*}{$\begin{array}{l}\text { Color } \\
\text { (Pt-Co } \\
\text { units) }\end{array}$} & \multirow{2}{*}{$\begin{array}{l}\text { Tem- } \\
\text { pera- } \\
\text { ture } \\
\left({ }^{0} \mathrm{C}\right)\end{array}$} \\
\hline & & & & $\begin{array}{l}\text { Calcu- } \\
\text { lated }\end{array}$ & $\begin{array}{c}\text { Residue } \\
\text { at } \\
180^{\circ} \mathrm{C}\end{array}$ & $\begin{array}{l}\text { Calcium- } \\
\text { magne- } \\
\text { sium }\end{array}$ & $\begin{array}{c}\text { Non- } \\
\text { carbo- } \\
\text { nate }\end{array}$ & & & & \\
\hline 2707140821552.01 & 1.8 & 0 & 0.02 & 1,065 & 1,190 & 710 & 566 & 1,610 & 7.7 & 5 & -- \\
\hline 2710370822748.01 & - & - & -- & - & 1,810 & -- & -- & 2,800 & - & - & 26.7 \\
\hline 2711180822853.01 & 1.4 & 0 & .04 & 2,430 & 2,860 & 1,788 & 1,650 & 2,835 & 7.5 & 0 & - \\
\hline 2715230823213.01 & - & - & -- & -- & 1,550 & - & -- & 2,380 & - & - & 25.0 \\
\hline 2716110822348.01 & - & - & -- & -- & 500 & 264 & -- & 789 & - & -- & -- \\
\hline 2716190822402.01 & - & - & -- & -- & 780 & -- & -- & 1,210 & - & -- & 27.8 \\
\hline 2716540823311.01 & - & - & -- & -- & 530 & 630 & -- & 840 & - & -- & -- \\
\hline 2717040823319.01 & - & - & -- & -- & -- & 498 & -- & -- & - & - & -- \\
\hline 2718320820648.01 & 1.5 & 0 & .07 & 496 & 574 & 376 & 189 & 740 & 7.5 & 5 & -- \\
\hline 2720190823226.01 & - & - & -- & -- & 930 & 800 & -- & 1,420 & - & - & -- \\
\hline $\begin{array}{l}2722480821846.01 \\
\quad(P-5)\end{array}$ & 1.7 & - & -- & 700 & - & 610 & 440 & 1,100 & 7.5 & -- & 27.0 \\
\hline \multirow[t]{2}{*}{2723070821645.01} & 1.3 & 0.0 & 0.0 & 926 & 835 & 650 & 491 & 1,110 & 8.0 & 0 & 27.0 \\
\hline & 1.4 & - & - & 840 & -- & 630 & 480 & 1,120 & 7.5 & - & 26.5 \\
\hline 2723240823831.01 & 1.6 & - & - & 1,560 & 1,650 & 940 & 810 & 2,380 & 7.4 & 0 & 26.5 \\
\hline 2723560821813.01 & 2.7 & .2 & .2 & 291 & 318 & 222 & 0 & 462 & 7.8 & 10 & -- \\
\hline 2724170823909.01 & - & - & - & -- & 680 & 830 & - & 1,050 & - & - & 26.0 \\
\hline 2725580823606.01 & - & - & -- & -- & 430 & 400 & - & 650 & - & - & -- \\
\hline 2727350820834.01 & 2.5 & - & .06 & -- & 305 & 188 & - & 488 & - & - & -- \\
\hline 2727400823730.01 & 1.0 & - & -- & 1,030 & 1,060 & 620 & 390 & 1,780 & 7.7 & 10 & 25.6 \\
\hline 2727500823803.01 & 1.8 & - & -- & 2,350 & 2,390 & 1,200 & 1,100 & 3,980 & 7.3 & 0 & 26.0 \\
\hline 2731310824303.01 & 1.7 & - & -- & 1,170 & 1,870 & 980 & 820 & 3,120 & 7.3 & 0 & 26.0 \\
\hline 2733330823329.01 & - & - & -- & -- & - & -- & -- & - & - & - & -- \\
\hline
\end{tabular}


Table 13.--Quality of water from the Suwannee and Ocala Limestones (middle water-bearing zone)

[Concentrations are in milligrams per liter, except as indicated]

\begin{tabular}{|c|c|c|c|c|c|c|c|c|c|c|c|}
\hline We11 number & $\begin{array}{l}\text { Date of } \\
\text { collection }\end{array}$ & $\begin{array}{c}\text { Sampling } \\
\text { depth } \\
\text { (feet) }\end{array}$ & Silica & Iron & $\begin{array}{l}\text { Cal- } \\
\text { cium }\end{array}$ & $\begin{array}{l}\text { Magne- } \\
\text { sium }\end{array}$ & Sodium & $\begin{array}{l}\text { Potas- } \\
\text { sium }\end{array}$ & $\begin{array}{l}\text { Bicar- } \\
\text { bonate }\end{array}$ & $\begin{array}{l}\text { Sul- } \\
\text { fate }\end{array}$ & $\begin{array}{l}\text { Chlor- } \\
\text { ide }\end{array}$ \\
\hline 2709430822814.01 & $12 / 15 / 71$ & $43-513$ & -- & 0.4 & - & -- & - & - & - & 875 & 278 \\
\hline 2710370822748.01 & $1 / 26 / 68$ & $28-424$ & -- & -- & - & -- & - & - & - & 1,750 & 300 \\
\hline 2711350822802.01 & $7 / 14 / 65$ & $53-720$ & -- & -- & - & -- & - & - & - & 1,660 & 70 \\
\hline 2712130820559.01 & $9 / 27 / 63$ & $58-845$ & -- & -- & - & -- & - & - & - & 52 & 45 \\
\hline 2712260821053.01 & $2 / 15 / 68$ & $70-593$ & -- & - & - & -- & - & - & - & 200 & 53 \\
\hline 2713330822332.01 & $5 / 24 / 62$ & $53-730$ & -- & -- & - & -- & - & - & - & 1,380 & 15 \\
\hline 2714200822257.01 & $5 / 19 / 66$ & $58-880$ & -- & -- & - & -- & - & - & - & 624 & 42 \\
\hline 2714240821858.01 & $9 / 27 / 62$ & 600 & -- & -- & - & -- & - & - & - & 592 & 40 \\
\hline 2714500822332.01 & $5 / 24 / 62$ & 660 & -- & -- & - & -- & - & - & - & 1,070 & 35 \\
\hline 2714570820322.03 & $2 / 21 / 75$ & 623 & -- & 350 & 257 & 3.9 & - & 8.2 & 29 & 574 & 36 \\
\hline 2715230823213.01 & $7 / 16 / 62$ & $138-418$ & -- & -- & - & -- & - & - & - & 1,140 & 175 \\
\hline 2716080823233.01 & $10 / 10 / 62$ & $77-515$ & -- & -- & - & -- & - & - & - & 1,100 & 364 \\
\hline 2716110822348.01 & $1 / 23 / 68$ & $122-349$ & -- & -- & - & -- & - & - & - & 29 & 146 \\
\hline 2716130823002.01 & $9 / 24 / 64$ & 43-601 & -- & -- & - & -- & - & - & - & 1,540 & 502 \\
\hline 2716190822402.01 & $12 / 07 / 67$ & $104-446$ & -- & -- & - & -- & - & - & - & 440 & 60 \\
\hline 2717030822737.01 & $9 / 24 / 71$ & 885 & -- & -- & - & -- & - & - & - & 85 & 104 \\
\hline 2718080823414.01 & $5 / 02 / 72$ & 732 & -- & 210 & - & -- & - & - & - & 250 & 180 \\
\hline 2718120821112.01 & $5 / 25 / 75$ & 800 & 31 & 100 & 69 & 25 & 15 & 1.8 & 276 & 55 & 11 \\
\hline 2718370822814.01 & $9 / 08 / 72$ & 625 & -- & 40 & - & -- & - & - & - & 250 & 60 \\
\hline 2719220822418.01 & $1 / 28 / 72$ & 691 & -- & 1,000 & - & -- & - & - & - & 410 & 60 \\
\hline 2720230823548.01 & $1 / 21 / 72$ & 546 & -- & 500 & - & -- & - & - & - & 490 & 120 \\
\hline 2720320822503.01 & $3 / 15 / 72$ & 1,038 & -- & 600 & - & -- & - & - & - & 550 & 28 \\
\hline 2721220821632.01 & $1 / 17 / 72$ & 925 & -- & 200 & - & -- & - & - & - & 250 & 26 \\
\hline 2722030821654.01 & $11 / 28 / 72$ & 1,011 & -- & 50 & - & -- & - & - & - & 500 & 26 \\
\hline 2723010821459.01 & $5 / 25 / 70$ & 700 & 21 & 80 & 220 & 82 & 13 & 2.9 & 157 & 750 & 18 \\
\hline
\end{tabular}


Table 13.--Quality of water from the Suwannee and Ocala Limestones (middle water-bearing zone)--Continued

\begin{tabular}{|c|c|c|c|c|c|c|c|c|c|c|c|}
\hline We11 number & $\begin{array}{l}\text { Date of } \\
\text { collection }\end{array}$ & $\begin{array}{l}\text { Sampling } \\
\text { depth } \\
\text { (feet) }\end{array}$ & Silica & Iron & $\begin{array}{l}\text { Cal- } \\
\text { cium }\end{array}$ & $\begin{array}{l}\text { Magne- } \\
\text { sium }\end{array}$ & Sodium & $\begin{array}{l}\text { Potas- } \\
\text { sium }\end{array}$ & $\begin{array}{l}\text { Bicar- } \\
\text { bonate }\end{array}$ & $\begin{array}{l}\text { Sul- } \\
\text { fate }\end{array}$ & $\begin{array}{l}\text { Chlor- } \\
\text { ide }\end{array}$ \\
\hline 2723100822004.01 & $11 / 09 / 72$ & 893 & -- & 0 & - & -- & - & - & - & 18 & 40 \\
\hline 2724050823120.01 & $6 / 17 / 76$ & 700 & 22 & 100 & 140 & 69 & 40 & 4.0 & 172 & 490 & 74 \\
\hline 2724340823241.01 & $6 / 17 / 76$ & 827 & 22 & 80 & 150 & 69 & 41 & 3.7 & 163 & 490 & 81 \\
\hline 2725570823023.01 & $12 / 26 / 72$ & 780 & -- & 0 & - & -- & - & - & - & 240 & 60 \\
\hline 2726410822958.01 & $6 / 17 / 76$ & 650 & -- & 60 & 150 & 68 & 20 & 2.9 & 171 & -- & 37 \\
\hline 2727000823153.01 & $10 / 10 / 72$ & 504 & -- & 40 & - & -- & - & - & - & 225 & 60 \\
\hline 2727070823828.01 & $6 / 11 / 76$ & 600 & 24 & 60 & 250 & 110 & 160 & 4.6 & 163 & 650 & 380 \\
\hline 2727310824146.01 & $6 / 10 / 76$ & 670 & 26 & 20 & 210 & 96 & 65 & 4.5 & 174 & 660 & 190 \\
\hline 2727350820834.01 & $10 / 22 / 65$ & $514-560$ & 11 & -- & 38 & 11 & 11 & 2.5 & 64 & 90 & 15 \\
\hline 2727380823831.01 & $6 / 29 / 72$ & 506 & -- & 30 & - & -- & - & - & - & 250 & 400 \\
\hline 2727580824153.01 & $3 / 22 / 72$ & 586 & -- & 1,350 & - & -- & - & - & - & 600 & 340 \\
\hline 2728180824051.01 & $6 / 11 / 76$ & 600 & 36 & 70 & 110 & 77 & 53 & 8.5 & 223 & 310 & 150 \\
\hline 2729020823428.01 & $6 / 10 / 76$ & $131-475$ & 10 & 260 & 170 & 74 & 34 & 2.8 & 57 & 630 & 81 \\
\hline 2729040822707.01 & $5 / 27 / 76$ & 500 & 25 & 260 & 89 & 38 & 18 & 2.9 & 186 & 260 & 24 \\
\hline 2729150823631.01 & $6 / 10 / 76$ & 800 & 23 & 270 & 260 & 100 & 150 & 4.3 & 162 & 760 & 360 \\
\hline \multirow[t]{7}{*}{2729310823319.01} & $6 / 03 / 76$ & 100 & -- & -- & - & -- & - & - & - & -- & - \\
\hline & & 200 & -- & -- & - & -- & - & - & - & -- & - \\
\hline & & 300 & -- & -- & - & -- & - & - & - & -- & - \\
\hline & & 470 & 22 & 20 & 280 & 100 & 63 & 3.4 & 149 & 820 & 230 \\
\hline & & 600 & 22 & 40 & 230 & 90 & 31 & 3.3 & 154 & 760 & 88 \\
\hline & & 700 & -- & -- & - & -- & - & - & - & -- & - \\
\hline & & 930 & 22 & 40 & 210 & 91 & 26 & 3.0 & 161 & 710 & 61 \\
\hline & $6 / 10 / 76$ & 600 & 30 & 190 & 210 & 87 & 72 & 6.0 & 171 & 630 & 190 \\
\hline \multirow{2}{*}{2729490824040.01} & $4 / 26 / 76$ & 600 & -- & -- & - & -- & - & - & - & -- & 420 \\
\hline & $6 / 10 / 76$ & 600 & 31 & 10 & 77 & 33 & 39 & 4.0 & 215 & 110 & 81 \\
\hline
\end{tabular}


Table 13.--Quality of water from the Suwannee and Ocala Limestones (middle water-bearing zone)--Continued

\begin{tabular}{|c|c|c|c|c|c|c|c|c|c|c|c|}
\hline We11 number & $\begin{array}{l}\text { Date of } \\
\text { collection }\end{array}$ & $\begin{array}{l}\text { Sampling } \\
\text { depth } \\
\text { (feet) }\end{array}$ & Silica & Iron & $\begin{array}{l}\text { Cal- } \\
\text { cium }\end{array}$ & $\begin{array}{l}\text { Magne- } \\
\text { sium }\end{array}$ & Sodium & $\begin{array}{c}\text { Potas- } \\
\text { sium }\end{array}$ & $\begin{array}{l}\text { Bicar- } \\
\text { bonate }\end{array}$ & $\begin{array}{l}\text { Sul- } \\
\text { fate }\end{array}$ & $\begin{array}{l}\text { Chlor- } \\
\text { ide }\end{array}$ \\
\hline 2730070822231.01 & $5 / 27 / 76$ & 600 & 23 & 280 & 71 & 30 & 13 & 2.8 & 180 & 130 & 17 \\
\hline 2730080820817.01 & $12 / 02 / 74$ & $510-650$ & 12 & 1,400 & 23 & 13 & 17 & 19 & 62 & 86 & 12 \\
\hline 2730090822506.01 & $5 / 27 / 76$ & 653 & 23 & 170 & 88 & 34 & 18 & 2.9 & 195 & 220 & 21 \\
\hline 2730420822728.01 & $5 / 27 / 76$ & 550 & 22 & 20 & 120 & 47 & 15 & 2.8 & 179 & 320 & 20 \\
\hline 2731040822407.01 & $5 / 27 / 76$ & 600 & 25 & 50 & 71 & 29 & 15 & 2.6 & 188 & 150 & 17 \\
\hline 2731290823544.01 & $8 / 10 / 71$ & 561 & -- & -- & - & -- & - & - & - & 525 & 540 \\
\hline 2731340823446.01 & $6 / 09 / 76$ & 547 & 21 & 80 & 250 & 100 & 170 & 4.4 & 152 & 740 & 390 \\
\hline 2731590823731.01 & $6 / 09 / 76$ & 525 & 25 & 50 & 190 & 99 & 100 & 5.5 & 188 & 640 & 230 \\
\hline 2732540820724.01 & $6 / 09 / 75$ & $444-748$ & 10 & 1,000 & 56 & 10 & 11 & - & - & 50 & 9.2 \\
\hline 2733430823343.01 & $6 / 09 / 76$ & 600 & 23 & 180 & 190 & 79 & 100 & 3.8 & 166 & 550 & 230 \\
\hline 2733470823541.01 & $6 / 09 / 76$ & 450 & 29 & 20 & 170 & 83 & 88 & 5.8 & 178 & 520 & 210 \\
\hline 2734530823337 & $6 / 09 / 76$ & 500 & 26 & 20 & 180 & 80 & 110 & 5.5 & 170 & 500 & 240 \\
\hline 2735170822152.01 & $5 / 19 / 76$ & 700 & 23 & 120 & 110 & 41 & 12 & 2.2 & 180 & 260 & 17 \\
\hline 2735500822519.01 & $5 / 19 / 76$ & 600 & 23 & 240 & 86 & 35 & 13 & 2.2 & 184 & 200 & 17 \\
\hline 2736290823224.01 & $6 / 09 / 76$ & 600 & 24 & 20 & 140 & 61 & 58 & 3.5 & 174 & 400 & 130 \\
\hline 2737090822930.01 & $6 / 19 / 76$ & 600 & 23 & 100 & 95 & 43 & 19 & 2.4 & 181 & 250 & 30 \\
\hline 2737310822703.01 & $5 / 19 / 76$ & 800 & 24 & 50 & 87 & 35 & 14 & 2.4 & 182 & 200 & 18 \\
\hline 2737420823225.01 & $6 / 09 / 76$ & 404 & 26 & 90 & 110 & 47 & 23 & 3.0 & 185 & 310 & 36 \\
\hline 2737530822106.01 & $5 / 11 / 76$ & 700 & -- & -- & - & -- & - & - & - & 310 & 19 \\
\hline 2737530822806.01 & $5 / 19 / 76$ & 600 & 25 & 70 & 87 & 36 & 15 & 2.5 & 185 & 230 & 19 \\
\hline 2738210823233.01 & $5 / 19 / 76$ & 600 & 26 & 30 & 130 & 56 & 35 & 3.3 & 171 & 370 & 88 \\
\hline 2738240822032.01 & $5 / 23 / 74$ & 800 & -- & -- & 40 & 22 & 18 & 1.6 & - & 3 & 15 \\
\hline 2738450823140.01 & $5 / 10 / 76$ & 600 & -- & -- & - & - & - & - & - & 360 & 60 \\
\hline 2739170821840.01 & $8 / 08 / 72$ & 510 & -- & -- & - & - & - & - & - & 130 & 13 \\
\hline 2740010822954.01 & $5 / 09 / 77$ & 575 & -- & -- & - & -- & - & - & - & 260 & 22 \\
\hline
\end{tabular}


Table 13.--Quality of water from the Suwannee and Ocala Limestones (middle water-bearing zone)--Continued

\begin{tabular}{|c|c|c|c|c|c|c|c|c|c|c|c|}
\hline We11 number & $\begin{array}{l}\text { Date of } \\
\text { collection }\end{array}$ & $\begin{array}{c}\text { Sampling } \\
\text { depth } \\
\text { (feet) }\end{array}$ & Silica & Iron & $\begin{array}{l}\text { Cal- } \\
\text { cium }\end{array}$ & $\begin{array}{l}\text { Magne- } \\
\text { sium }\end{array}$ & Sodium & $\begin{array}{c}\text { Potas- } \\
\text { sium }\end{array}$ & $\begin{array}{l}\text { Bicar- } \\
\text { bonate }\end{array}$ & $\begin{array}{l}\text { Sul- } \\
\text { fate }\end{array}$ & $\begin{array}{l}\text { Chlor- } \\
\text { ide }\end{array}$ \\
\hline 2740170822721.01 & $5 / 23 / 74$ & 600 & -- & -- & 89 & 11 & 19 & 1.1 & - & 37 & 27 \\
\hline 2740300822852.01 & $5 / 09 / 77$ & 600 & - & - & - & -- & - & - & - & 230 & 26 \\
\hline 2740420822759.01 & $5 / 10 / 76$ & 700 & - & - & - & -- & - & - & - & 270 & 19 \\
\hline 2741090822825.01 & $5 / 29 / 75$ & $70-550$ & - & - & - & -- & - & - & - & -- & 29 \\
\hline 2741180822351.01 & $5 / 22 / 74$ & $145-575$ & - & - & 89 & 34 & 13 & 1.9 & - & 190 & 19 \\
\hline 2741540822911.01 & $5 / 10 / 76$ & $38-545$ & - & - & - & -- & - & - & - & 260 & 20 \\
\hline 2742520822324.01 & $5 / 12 / 76$ & $192-700$ & -- & -- & - & -- & - & - & - & 270 & 19 \\
\hline 2742560822016.01 & $1 / 22 / 75$ & $129-664$ & -- & - & 82 & 1.5 & 6 & - & 166 & 166 & 18 \\
\hline \multirow[t]{2}{*}{2744060822407.01} & $5 / 22 / 74$ & 450 & - & -- & 95 & 36 & 15 & 1.7 & - & 190 & 20 \\
\hline & $5 / 09 / 77$ & & - & -- & - & - & - & - & - & 200 & 21 \\
\hline 2744140822649.01 & $5 / 21 / 74$ & 600 & - & - & 240 & 110 & 90 & 3.1 & - & 700 & 290 \\
\hline 2744550822536.01 & $9 / 07 / 76$ & 500 & - & -- & - & - & - & - & - & -- & 290 \\
\hline
\end{tabular}


Table 13.--Quality of water from the Suwannee and Ocala Limestones (middle water-bearing zone)--Continued

\begin{tabular}{|c|c|c|c|c|c|c|c|c|c|c|c|}
\hline \multirow{2}{*}{ Well number } & \multirow{2}{*}{$\begin{array}{l}\text { Fluor- } \\
\text { ide }\end{array}$} & \multirow{2}{*}{$\begin{array}{l}\text { Ni- } \\
\text { trate }\end{array}$} & \multirow{2}{*}{$\begin{array}{l}\text { Phos- } \\
\text { phate }\end{array}$} & \multicolumn{2}{|c|}{$\begin{array}{l}\text { Dissolved } \\
\text { solids }\end{array}$} & \multicolumn{2}{|c|}{ Hardness } & \multirow{2}{*}{$\begin{array}{l}\text { Specific } \\
\text { conduc- } \\
\text { tance } \\
\text { (umho/cm } \\
\text { at } 25^{\circ} \mathrm{C} \text { ) }\end{array}$} & \multirow{2}{*}{$\begin{array}{c}\mathrm{pH} \\
\text { (units) }\end{array}$} & \multirow{2}{*}{$\begin{array}{l}\text { Color } \\
\text { (Pt-Co } \\
\text { units) }\end{array}$} & \multirow{2}{*}{$\begin{array}{l}\text { Tem- } \\
\text { pera- } \\
\text { ture } \\
\left({ }^{0} \mathrm{C}\right)\end{array}$} \\
\hline & & & & $\begin{array}{l}\text { Calcu- } \\
\text { lated }\end{array}$ & $\begin{array}{c}\text { Residue } \\
\text { at } \\
180^{\circ} \mathrm{C}\end{array}$ & $\begin{array}{l}\text { Calcium- } \\
\text { magne- } \\
\text { sium }\end{array}$ & $\begin{array}{l}\text { Non- } \\
\text { carbo- } \\
\text { nate }\end{array}$ & & & & \\
\hline 2709430822814.01 & - & - & - & 2,350 & -- & 2,200 & - & 3,400 & - & -- & 27.0 \\
\hline 2710370822748.01 & - & - & - & 1,810 & -- & - & - & 2,800 & - & -- & 26.6 \\
\hline 2711350822802.01 & - & - & - & 1,880 & -- & 1,870 & - & 2,700 & - & -- & -- \\
\hline 2712130820559.01 & - & - & - & 980 & - & 730 & - & 1,300 & - & -- & 25 \\
\hline 2712260821053.01 & - & - & - & 640 & -- & -- & - & 830 & - & -- & -- \\
\hline 2713330822332.01 & - & - & - & 1,700 & -- & -- & - & 2,400 & - & -- & 25.6 \\
\hline 2714200822257.01 & - & - & - & 1,050 & -- & 800 & - & 1,470 & - & -- & -- \\
\hline 2714240821858.01 & - & - & - & 980 & -- & 810 & - & 1,350 & - & -- & 27.2 \\
\hline 2714500822332.01 & - & - & - & 1,420 & -- & -- & - & 2,060 & - & - & 26.1 \\
\hline 2714570820322.03 & 0.8 & 1.1 & 22 & -- & 1,076 & 659 & - & 1,025 & 7.8 & -- & 27 \\
\hline 2715230823213.01 & - & - & - & -- & 1,550 & -- & - & 2,380 & - & -- & 25 \\
\hline 2716080823233.01 & - & - & - & 1,900 & - & -- & - & 2,750 & - & -- & 25.6 \\
\hline 2716110822348.01 & - & - & - & - & 500 & 264 & - & 789 & - & -- & -- \\
\hline 2716130823002.01 & - & - & - & 2,500 & -- & 1,920 & - & 3,650 & - & -- & 27.7 \\
\hline 2716190822402.01 & - & - & - & 780 & -- & -- & - & 1,210 & - & -- & 27.7 \\
\hline 2717030822737.01 & - & - & - & -- & 420 & 120 & - & 510 & - & -- & -- \\
\hline 2718080823414.01 & - & - & - & -- & 1,300 & 1,200 & - & 1,800 & - & -- & 27.0 \\
\hline 2718120821112.01 & .7 & - & - & 349 & 388 & 280 & 54 & 578 & 7.5 & 0 & 25.0 \\
\hline 2718370822814.01 & - & - & - & -- & 750 & 540 & - & 950 & - & -- & 26.0 \\
\hline 2719220822418.01 & - & - & - & -- & 800 & 640 & - & 1,050 & - & -- & -- \\
\hline 2720230823548.01 & - & - & - & -- & 830 & 720 & - & 1,100 & - & -- & 26.5 \\
\hline 2720320822503.01 & - & - & - & -- & 860 & 680 & - & 1,130 & - & -- & - \\
\hline 2721220821632.01 & - & - & - & -- & 940 & 630 & - & 1,250 & - & -- & 27.5 \\
\hline 2722030821654.01 & - & - & - & -- & 900 & 950 & - & 1,200 & - & -- & - \\
\hline 2723010821459.01 & 1.1 & - & - & 1,210 & 1,320 & 910 & 790 & 1,580 & 7.5 & 0 & 31.0 \\
\hline
\end{tabular}


Table 13.--Quality of water from the Suwannee and Ocala Limestones (middle water-bearing zone)--Continued

\begin{tabular}{|c|c|c|c|c|c|c|c|c|c|c|c|}
\hline \multirow[b]{2}{*}{ Well number } & \multirow{2}{*}{$\begin{array}{l}\text { Fluor- } \\
\text { ide }\end{array}$} & \multirow{2}{*}{$\begin{array}{l}\mathrm{Ni}- \\
\text { trate }\end{array}$} & \multirow{2}{*}{$\begin{array}{l}\text { Phos- } \\
\text { phate }\end{array}$} & \multicolumn{2}{|c|}{$\begin{array}{l}\text { Dissolved } \\
\text { solids }\end{array}$} & \multicolumn{2}{|c|}{ Hardness } & \multirow{2}{*}{$\begin{array}{l}\text { Specific } \\
\text { conduc- } \\
\text { tance } \\
\text { (umho/cm } \\
\text { at } 25^{\circ} \mathrm{C} \text { ) }\end{array}$} & \multirow{2}{*}{$\begin{array}{c}\mathrm{pH} \\
\text { (units) }\end{array}$} & \multirow{2}{*}{$\begin{array}{l}\text { Color } \\
\text { (Pt-Co } \\
\text { units) }\end{array}$} & \multirow{2}{*}{$\begin{array}{l}\text { Tem- } \\
\text { pera- } \\
\text { ture } \\
\left({ }^{0} \mathrm{C}\right)\end{array}$} \\
\hline & & & & $\begin{array}{l}\text { Calcu- } \\
\text { lated }\end{array}$ & $\begin{array}{c}\text { Residue } \\
\text { at } \\
180^{\circ} \mathrm{C}\end{array}$ & $\begin{array}{l}\text { Calcium- } \\
\text { magne- } \\
\text { sium }\end{array}$ & $\begin{array}{c}\text { Non- } \\
\text { carbo- } \\
\text { nate }\end{array}$ & & & & \\
\hline 2723100822004.01 & - & - & - & -- & 395 & 250 & - & 480 & - & -- & -- \\
\hline 2724050823120.01 & 1.2 & - & - & 947 & 1,040 & 660 & 520 & 1,440 & 7.4 & 0 & -- \\
\hline 2724340823241.01 & 1.3 & - & - & 960 & 992 & 680 & 550 & 1,450 & 7.4 & 0 & 27.0 \\
\hline 2725570823023.01 & - & - & - & -- & 740 & 580 & - & 970 & - & -- & 26.5 \\
\hline 2726410822958.01 & 1.2 & - & - & -- & 940 & 680 & 540 & 1,275 & 7.5 & 0 & -- \\
\hline 2727000823153.01 & - & - & - & -- & 680 & 700 & - & 875 & - & -- & -- \\
\hline 2727070823828.01 & 1.9 & - & - & 1,680 & 1,770 & 1,100 & 960 & 2,620 & 7.6 & 0 & 25.0 \\
\hline 2727310824146.01 & 1.9 & - & - & 1,360 & 1,460 & 940 & 800 & 2,050 & 7.4 & 0 & 27.0 \\
\hline 2727350820834.01 & .6 & 0.4 & 0.30 & 212 & 232 & 144 & 92 & 382 & 7.9 & 5 & -- \\
\hline 2727380823831.01 & - & - & - & -- & 1,300 & 850 & - & 1,700 & - & -- & 26.0 \\
\hline 2727580824153.01 & - & - & - & -- & 1,550 & 1,200 & - & 2,200 & - & -- & 26.0 \\
\hline 2728180824051.01 & 3.2 & - & - & 870 & 934 & 610 & 420 & 1,420 & 7.4 & 0 & 26.0 \\
\hline 2729020823428.01 & 1.4 & - & - & 1,040 & 1,160 & 740 & 700 & 1,520 & 7.3 & 0 & 26.0 \\
\hline 2729040822707.01 & 1.1 & - & - & 566 & 618 & 400 & 240 & 861 & 7.4 & 0 & 26.0 \\
\hline 2729150823631.01 & 2.0 & - & - & 1,760 & 1,830 & 1,100 & 950 & 2,680 & 7.3 & 0 & 26.5 \\
\hline \multirow[t]{7}{*}{2729310823319.01} & - & - & - & -- & -- & -- & - & 2,230 & 7.6 & -- & -- \\
\hline & - & - & - & -- & -- & -- & - & 2,240 & 7.6 & -- & -- \\
\hline & - & - & - & -- & -- & -- & - & 2,260 & 7.6 & -- & -- \\
\hline & 1.8 & - & - & 1,620 & 1,870 & 1,100 & 1,000 & 2,230 & 7.3 & 0 & -- \\
\hline & 1.6 & - & - & 1,320 & 1,470 & 960 & 840 & 1,800 & 7.7 & 0 & -- \\
\hline & - & - & - & -- & -- & -- & - & 1,700 & 7.8 & -- & -- \\
\hline & 1.6 & - & - & 1,220 & 1,400 & 920 & 790 & 1,730 & 7.6 & 0 & -- \\
\hline 2729460823804.01 & 2.3 & - & - & 1,330 & 1,450 & 900 & 760 & 1,980 & 7.3 & 0 & 26.0 \\
\hline \multirow[t]{2}{*}{2729490824040.01} & - & - & - & -- & - & -- & - & 2,280 & - & -- & -- \\
\hline & 2.2 & - & - & 491 & 528 & 340 & 160 & 870 & 7.5 & 0 & 25.5 \\
\hline
\end{tabular}


Table 13.--Quality of water from the Suwannee and Ocala Limestones (middle water-bearing zone)--Continued

\begin{tabular}{|c|c|c|c|c|c|c|c|c|c|c|c|}
\hline \multirow[b]{2}{*}{ We11 number } & \multirow{2}{*}{$\begin{array}{l}\text { Fluor- } \\
\text { ide }\end{array}$} & \multirow{2}{*}{$\begin{array}{l}\mathrm{Ni}- \\
\text { trate }\end{array}$} & \multirow{2}{*}{$\begin{array}{l}\text { Phos- } \\
\text { phate }\end{array}$} & \multicolumn{2}{|c|}{$\begin{array}{l}\text { Dissolved } \\
\text { solids }\end{array}$} & \multicolumn{2}{|c|}{ Hardness } & \multirow{2}{*}{$\begin{array}{l}\text { Specific } \\
\text { conduc- } \\
\text { tance } \\
\text { (umho/cm } \\
\text { at } 25^{\circ} \mathrm{C} \text { ) }\end{array}$} & \multirow{2}{*}{$\begin{array}{c}\mathrm{pH} \\
\text { (units) }\end{array}$} & \multirow{2}{*}{$\begin{array}{l}\text { Color } \\
\text { (Pt-Co } \\
\text { units) }\end{array}$} & \multirow{2}{*}{$\begin{array}{l}\text { Tem- } \\
\text { pera- } \\
\text { ture } \\
\left({ }^{0} \mathrm{C}\right)\end{array}$} \\
\hline & & & & $\begin{array}{l}\text { Calcu- } \\
\text { lated }\end{array}$ & $\begin{array}{c}\text { Residue } \\
\text { at } \\
180^{\circ} \mathrm{C}\end{array}$ & $\begin{array}{l}\text { Calcium- } \\
\text { magne- } \\
\text { sium }\end{array}$ & $\begin{array}{l}\text { Non- } \\
\text { carbo- } \\
\text { nate }\end{array}$ & & & & \\
\hline 2730070822231.01 & 1.1 & - & - & 387 & 446 & 310 & 160 & 640 & 7.7 & 0 & 26.0 \\
\hline 2730080820817.01 & .84 & 0.01 & 0.43 & 222 & 225 & 111 & 49 & 320 & 8.9 & -- & -- \\
\hline 2730090822506.01 & 1.0 & - & - & 519 & 578 & 380 & 220 & 827 & 7.3 & 0 & -- \\
\hline 2730420822728.01 & 1.1 & - & - & 654 & 744 & 510 & 370 & 957. & 7.3 & 0 & 27.0 \\
\hline 2731040822407.01 & 1.1 & - & - & 414 & 498 & 310 & 160 & 687 & 7.6 & 0 & 26.0 \\
\hline 2731290823544.01 & - & - & - & -- & 1,250 & 990 & -- & 1,600 & - & -- & 26.0 \\
\hline 2731340823446.01 & 1.5 & - & - & 1,770 & 1,840 & 1,100 & 930 & 2,740 & 7.6 & 0 & 24.0 \\
\hline 2731590823731.01 & 1.7 & - & - & 1,400 & 1,520 & 900 & 750 & 2,150 & 7.6 & 0 & 25.0 \\
\hline 2732540820724.01 & .54 & .97 & - & -- & 556 & 185 & 43 & 328 & 7.8 & 20 & -- \\
\hline 2733430823343.01 & 1.3 & - & - & 1,270 & 1,350 & 810 & 680 & 2,040 & 7.4 & 0 & 26.0 \\
\hline 2733470823541.01 & 1.4 & - & - & 1,210 & 1,340 & 780 & 640 & 1,920 & 7.5 & 0 & 25.0 \\
\hline 2734530823337 & 1.3 & - & - & 1,240 & 1,370 & 790 & 650 & 2,050 & 7.4 & 0 & 26.5 \\
\hline 2735170822152.01 & 1.3 & - & - & 564 & 634 & 450 & 310 & 808 & 7.5 & 0 & -- \\
\hline 2735500822519.01 & 1.2 & - & - & 477 & 566 & 370 & 220 & 715 & 7.4 & 0 & -- \\
\hline 2736290823224.01 & 1.0 & - & - & 914 & 1,020 & 610 & 470 & 1,440 & 7.2 & 0 & 26.5 \\
\hline 2737090822930.01 & 1.1 & - & - & 560 & 654 & 420 & 270 & 830 & 7.3 & 0 & -- \\
\hline 2737310822703.01 & 1.1 & - & - & 480 & 544 & 370 & 220 & 733 & 7.4 & 0 & -- \\
\hline 2737420823225.01 & 1.0 & - & - & 657 & 738 & 480 & 330 & 1,000 & 7.3 & 0 & -- \\
\hline 2737530822106.01 & - & - & - & -- & 660 & -- & -- & 860 & - & -- & 29 \\
\hline 2737530822806.01 & 1.1 & - & - & 515 & 582 & 370 & 220 & 750 & 7.4 & 0 & -- \\
\hline 2738210823233.01 & 1.1 & - & - & 806 & 894 & 570 & 430 & 1,300 & 7.2 & 0 & -- \\
\hline 2738240822032.01 & - & - & - & -- & 335 & 190 & -- & 409 & - & -- & 24.5 \\
\hline 2738450823140.01 & - & - & - & -- & 808 & -- & -- & 1,100 & - & -- & 26.0 \\
\hline 2739170821840.01 & - & - & - & -- & 490 & 500 & -- & 600 & - & -- & -- \\
\hline 2740010822954.01 & - & - & - & -- & 651 & -- & -- & 832 & - & -- & 25.5 \\
\hline
\end{tabular}


Table 13.--Quality of water from the Suwannee and Ocala Limestones (middle water-bearing zone)--Continued

\begin{tabular}{|c|c|c|c|c|c|c|c|c|c|c|c|}
\hline \multirow[b]{2}{*}{ We11 number } & \multirow{2}{*}{$\begin{array}{l}\text { Fluor- } \\
\text { ide }\end{array}$} & \multirow{2}{*}{$\begin{array}{l}\mathrm{Ni-} \\
\text { trate }\end{array}$} & \multirow{2}{*}{$\begin{array}{l}\text { Phos- } \\
\text { phate }\end{array}$} & \multicolumn{2}{|c|}{$\begin{array}{l}\text { Dissolved } \\
\text { solids }\end{array}$} & \multicolumn{2}{|c|}{ Hardness } & \multirow{2}{*}{$\begin{array}{l}\text { Specific } \\
\text { conduc- } \\
\text { tance } \\
\text { (umho/cm } \\
\text { at } 25^{\circ} \mathrm{C} \text { ) }\end{array}$} & \multirow{2}{*}{$\underset{\text { (units) }}{\mathrm{pH}}$} & \multirow{2}{*}{$\begin{array}{l}\text { Color } \\
\text { (Pt-Co } \\
\text { units) }\end{array}$} & \multirow{2}{*}{$\begin{array}{l}\text { Tem- } \\
\text { pera- } \\
\text { ture } \\
\left({ }^{0} \mathrm{C}\right)\end{array}$} \\
\hline & & & & $\begin{array}{l}\text { Calcu- } \\
\text { lated }\end{array}$ & $\begin{array}{c}\text { Residue } \\
\text { at } \\
180^{\circ} \mathrm{C}\end{array}$ & $\begin{array}{l}\text { Calcium- } \\
\text { magne- } \\
\text { sium }\end{array}$ & $\begin{array}{l}\text { Non- } \\
\text { carbo- } \\
\text { nate }\end{array}$ & & & & \\
\hline 2740170822721.01 & - & - & - & -- & 450 & 270 & -- & 557 & - & - & -- \\
\hline 2740300822852.01 & - & - & - & -- & 582 & -- & -- & 767 & - & -- & -- \\
\hline 2740420822759.01 & - & - & - & -- & 608 & -- & -- & 840 & - & -- & 25.5 \\
\hline 2741090822825.01 & - & - & - & -- & 700 & -- & -- & 940 & - & -- & 26.0 \\
\hline 2741180822351.01 & - & - & - & -- & 580 & 360 & -- & 726 & - & -- & 25.5 \\
\hline 2741540822911.01 & - & - & - & -- & 602 & -- & -- & 810 & - & -- & 25.5 \\
\hline 2742520822324.01 & - & - & - & -- & 596 & -- & -- & 800 & - & -- & 25.5 \\
\hline 2742560822016.01 & - & 0.48 & - & -- & 504 & 211 & 44 & 697 & 7.7 & 10 & - \\
\hline 2744060822407.01 & - & - & - & -- & 570 & 390 & -- & 759 & - & -- & 24.5 \\
\hline & - & - & - & -- & 569 & -- & -- & 744 & - & -- & 25.5 \\
\hline 2744140822649.01 & - & - & - & -- & 1,560 & 1,100 & -- & 2,180 & - & -- & -- \\
\hline 2744550822536.01 & - & - & - & -- & 1,450 & - & -- & 2,000 & - & -- & 25.5 \\
\hline
\end{tabular}


Table 14.--Quality of water from the Avon Park Limestone (lower water-bearing zone)

[Concentrations are in milligrams per liter, except as indicated]

\begin{tabular}{|c|c|c|c|c|c|c|c|c|c|c|c|}
\hline We11 number & $\begin{array}{l}\text { Date of } \\
\text { collection }\end{array}$ & $\begin{array}{l}\text { Sampling } \\
\text { depth } \\
\text { (feet) }\end{array}$ & Silica & Iron & $\begin{array}{l}\text { Cal- } \\
\text { cium }\end{array}$ & $\begin{array}{l}\text { Magne- } \\
\text { sium }\end{array}$ & Sodium & $\begin{array}{l}\text { Potas- } \\
\text { sium }\end{array}$ & $\begin{array}{l}\text { Bicar- } \\
\text { bonate }\end{array}$ & $\begin{array}{l}\text { Sul- } \\
\text { fate }\end{array}$ & $\begin{array}{l}\text { Chlor- } \\
\text { ide }\end{array}$ \\
\hline 2712220820423.01 & $5 / 16 / 72$ & $188-1,507$ & -- & 20 & -- & -- & -- & -- & - & 310 & 80 \\
\hline 2714570820322.05 & $2 / 18 / 75$ & 1,400 & 8.2 & 550 & 216 & 16 & 42 & -- & 26 & 608 & 24 \\
\hline 2716070822328.01 & $3 / 12 / 75$ & 1,157 & -- & - & 540 & 150 & -- & -- & 154 & 1,600 & 85 \\
\hline 2717030820318.01 & $3 / 30 / 75$ & $300-1,400$ & 23 & 610 & 292 & 62 & 15 & -- & 147 & 794 & 29 \\
\hline 2717470821124.01 & $4 / 02 / 75$ & $1,400 ?$ & -- & - & -- & -- & -- & -- & - & -- & 12 \\
\hline 2718020820627.01 & $5 / 25 / 76$ & 1,535 & 42 & 210 & 63 & 27 & 27 & 2.1 & 276 & 77 & 17 \\
\hline \multirow[t]{4}{*}{2720530823202.01} & $11 / 29 / 73$ & 1,270 & 16 & - & 1,300 & 970 & 10,000 & 300 & 188 & 2,900 & 19,000 \\
\hline & $12 / 06 / 73$ & 1,495 & 15 & - & 1,300 & 940 & 9,000 & 310 & 190 & 3,100 & 19,000 \\
\hline & $12 / 09 / 73$ & 1,160 & 24 & 170 & 400 & 300 & 600 & 18 & 144 & 1,400 & 1,400 \\
\hline & $1 / 02 / 74$ & 1,645 & 23 & - & 690 & 300 & 1,900 & 40 & 150 & 1,600 & 3,700 \\
\hline 2724130821257.01 & $5 / 24 / 76$ & 1,100 & 21 & 430 & 150 & 66 & 13 & 2.8 & 162 & 530 & 17 \\
\hline 2724230820519.01 & $5 / 24 / 76$ & 1,320 & 43 & 520 & 54 & 24 & 13 & 2.1 & 265 & 20 & 11 \\
\hline 2726120821424.01 & $5 / 25 / 76$ & 1,120 & 22 & 80 & 90 & 37 & 12 & 2.4 & 180 & 250 & 15 \\
\hline 2726350822510.01 & $5 / 27 / 76$ & 1,250 & 23 & 40 & 140 & 64 & 14 & 2.9 & 170 & 470 & 50 \\
\hline 2728150821051.01 & $5 / 24 / 76$ & 1,200 & 28 & 160 & 41 & 20 & 13 & 1.9 & 184 & 47 & 11 \\
\hline \multirow[t]{2}{*}{2729130823304.01} & $6 / 16 / 76$ & 1,060 & 22 & 100 & 370 & 130 & 220 & 4.0 & 160 & 890 & 670 \\
\hline & $3 / 26 / 62$ & & -- & - & -- & -- & -- & -- & - & 726 & 200 \\
\hline 2730000820651.01 & $8 / 27 / 76$ & 1,244 & 18 & 20 & 52 & 19 & 8.7 & 1.5 & 155 & 72 & 12 \\
\hline 2730000820829.01 & $10 / 16 / 74$ & 1,260 & 19 & 50 & 68 & 23 & 10 & 1.6 & 190 & 82 & 10 \\
\hline 2730240822123.01 & $5 / 24 / 76$ & 1,100 & 22 & 50 & 82 & 32 & 12 & 2.4 & 182 & 200 & 16 \\
\hline 2731350823547.01 & $6 / 21 / 76$ & 2,660 & 24 & 80 & 300 & 130 & 350 & 9.0 & 156 & 860 & 760 \\
\hline 2731500820614.01 & $5 / 19 / 76$ & 1,150 & 22 & 510 & 43 & 19 & 9.0 & .7 & 188 & 22 & 13 \\
\hline 2735360821505.01 & $5 / 19 / 76$ & 1,710 & 22 & 50 & 150 & 48 & 11 & 2.1 & 169 & 430 & 15 \\
\hline 2735470822934.01 & $3 / 10 / 77$ & 1,100 & -- & 50 & 190 & 78 & 90 & 3.8 & 160 & 510 & 220 \\
\hline 2736240821640.01 & $5 / 19 / 76$ & 1,100 & 21 & 60 & 230 & 63 & 11 & 2.2 & 161 & 650 & 16 \\
\hline
\end{tabular}


Table 14.--Quality of water from the Avon Park Limestone (lower water-bearing zone)--Continued

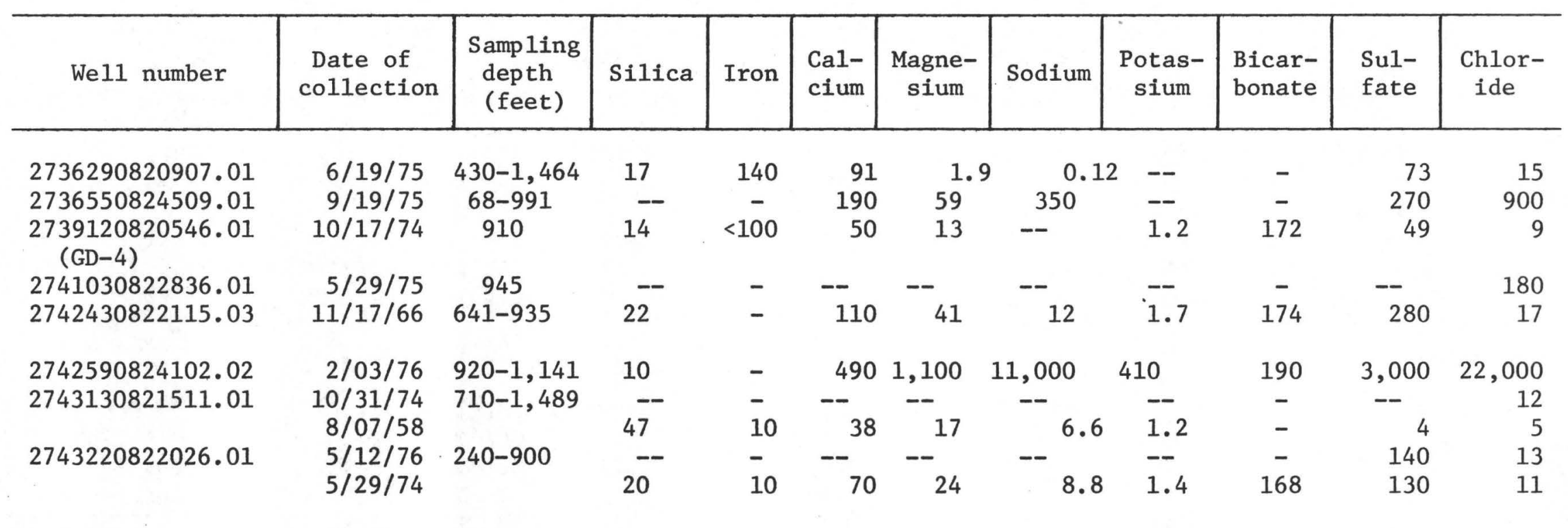


Table 14.--Quality of water from the Avon Park Limestone (lower water-bearing zone)--Continued

\begin{tabular}{|c|c|c|c|c|c|c|c|c|c|c|c|}
\hline \multirow{2}{*}{ Well number } & \multirow{2}{*}{$\begin{array}{l}\text { Fluor- } \\
\text { ide }\end{array}$} & \multirow{2}{*}{$\begin{array}{l}\text { Ni- } \\
\text { trate }\end{array}$} & \multirow{2}{*}{$\begin{array}{l}\text { Phos- } \\
\text { phate }\end{array}$} & \multicolumn{2}{|c|}{$\begin{array}{l}\text { Dissolved } \\
\text { solids }\end{array}$} & \multicolumn{2}{|c|}{ Hardness } & \multirow{2}{*}{$\begin{array}{l}\text { Specific } \\
\text { conduc- } \\
\text { tance } \\
\text { (umho/cm } \\
\text { at } 25^{\circ} \mathrm{C} \text { ) }\end{array}$} & \multirow{2}{*}{$\begin{array}{c}\mathrm{pH} \\
\text { (units) }\end{array}$} & \multirow{2}{*}{$\begin{array}{l}\text { Color } \\
\text { (Pt-Co } \\
\text { units) }\end{array}$} & \multirow{2}{*}{$\begin{array}{l}\text { Tem- } \\
\text { pera- } \\
\text { ture } \\
\left({ }^{0} \mathrm{C}\right)\end{array}$} \\
\hline & & & & $\begin{array}{l}\text { Calcu- } \\
\text { lated }\end{array}$ & $\begin{array}{c}\text { Residue } \\
\text { at } \\
180^{\circ} \mathrm{C}\end{array}$ & $\begin{array}{l}\text { Calcium- } \\
\text { magne- } \\
\text { sium }\end{array}$ & $\begin{array}{l}\text { Non- } \\
\text { carbo- } \\
\text { nate }\end{array}$ & & & & \\
\hline 2712220820423.01 & - & -- & -- & -- & 850 & 1,100 & -- & 1,150 & - & -- & -- \\
\hline 2714570820322.05 & 0.9 & 0.72 & 21 & -- & 1,164 & 604 & 578 & 1,225 & 8.1 & -- & -- \\
\hline 2716070822328.01 & 2.0 & -- & -- & -- & 2,100 & 2,000 & 1,900 & 2,800 & 7.6 & -- & -- \\
\hline 2717030820318.01 & - & .44 & 4.6 & -- & 1,406 & -- & -- & -- & - & -- & 31.1 \\
\hline 2717470821124.01 & - & -- & -- & -- & -- & -- & -- & 1,040 & - & -- & -- \\
\hline 2718020820627.01 & 1.4 & -- & -- & 398 & 436 & 270 & 48 & 650 & 7.6 & 0 & 25.5 \\
\hline \multirow[t]{4}{*}{2720530823202.01} & 1.8 & -- & -- & 34,600 & 34,200 & 7,300 & 7,100 & 42,000 & 7.6 & -- & -- \\
\hline & 1.9 & -- & -- & 34,400 & 34,500 & 7,200 & 7,000 & 43,000 & 7.7 & -- & -- \\
\hline & .2 & -- & -- & 4,210 & 4,450 & 2,200 & 2,100 & 5,940 & 7.6 & 6 & -- \\
\hline & 1.5 & -- & -- & 8,390 & 8,720 & 3,100 & 3,000 & 11,200 & 7.8 & -- & 31.5 \\
\hline 2724130821257.01 & .9 & -- & -- & 904 & 1,010 & 670 & 540 & 1,250 & 7.4 & 0 & 30.0 \\
\hline 2724230820519.01 & 1.5 & -- & -- & 303 & 316 & 240 & 20 & 500 & 7.7 & 0 & 27.5 \\
\hline 2726120821424.01 & .8 & -- & -- & 547 & 608 & 410 & 260 & 813 & 7.8 & 0 & 29.0 \\
\hline 2726350822510.01 & 1.1 & -- & -- & 874 & 966 & 640 & 500 & 1,190 & 7.6 & 0 & 30.5 \\
\hline 2728150821051.01 & .9 & -- & -- & 265 & 292 & 200 & 46 & 430 & 7.8 & 0 & -- \\
\hline \multirow[t]{2}{*}{2729130823304.01} & 1.7 & -- & -- & 2,410 & 2,460 & 1,500 & 1,400 & 3,780 & 7.3 & 0 & -- \\
\hline & - & -- & -- & 1,450 & -- & 1,060 & -- & 1,944 & - & -- & 27.8 \\
\hline 2730000820651.01 & .7 & -- & -- & 269 & 286 & 220 & 91 & -- & - & 0 & 30.0 \\
\hline 2730000820829.01 & .7 & .12 & 1.2 & 330 & 368 & 265 & 75 & 430 & 8.5 & 5 & -- \\
\hline 2730240822123.01 & 1.1 & -- & -- & 480 & 518 & 360 & 210 & 750 & 7.4 & 0 & 30.0 \\
\hline 2731350823547.01 & 1.5 & -- & -- & 2,530 & 2,640 & 1,300 & 1,200 & 4,300 & - & 0 & 26.5 \\
\hline 2731500820614.01 & 1.2 & -- & -- & 223 & 232 & 190 & 32 & 380 & 7.4 & 0 & -- \\
\hline 2735360821505.01 & 1.2 & -- & -- & 774 & 824 & 580 & 450 & 1,320 & 7.5 & 0 & -- \\
\hline 2735470822934.01 & 1.0 & -- & -- & 1,210 & 1,270 & 810 & 680 & 1,670 & 7.7 & 0 & 28.5 \\
\hline 2736240821640.01 & 1.8 & -- & -- & 1,090 & 1,140 & 850 & 720 & 1,320 & 7.5 & 0 & -- \\
\hline
\end{tabular}


Table 14.--Quality of water from the Avon Park Limestone (lower water-bearing zone)--Continued

\begin{tabular}{|c|c|c|c|c|c|c|c|c|c|c|c|}
\hline \multirow{2}{*}{ We11 number } & \multirow{2}{*}{$\begin{array}{l}\text { Fluor- } \\
\text { ide }\end{array}$} & \multirow{2}{*}{$\begin{array}{l}\mathrm{Ni-} \\
\text { trate }\end{array}$} & \multirow{2}{*}{$\begin{array}{l}\text { Phos- } \\
\text { phate }\end{array}$} & \multicolumn{2}{|c|}{$\begin{array}{l}\text { Dissolved } \\
\text { solids }\end{array}$} & \multicolumn{2}{|c|}{ Hardness } & \multirow{2}{*}{$\begin{array}{l}\text { Specific } \\
\text { conduc- } \\
\text { tance } \\
\text { (umho/cm } \\
\text { at } 25^{\circ} \mathrm{C} \text { ) }\end{array}$} & \multirow{2}{*}{$\begin{array}{c}\mathrm{pH} \\
\text { (units) }\end{array}$} & \multirow{2}{*}{$\begin{array}{l}\text { Color } \\
\text { (Pt-Co } \\
\text { units) }\end{array}$} & \multirow{2}{*}{$\begin{array}{l}\text { Tem- } \\
\text { pera- } \\
\text { ture } \\
\left({ }^{\circ} \mathrm{C}\right)\end{array}$} \\
\hline & & & & $\begin{array}{l}\text { Calcu- } \\
\text { lated }\end{array}$ & $\begin{array}{c}\text { Residue } \\
\text { at } \\
180^{\circ} \mathrm{C}\end{array}$ & $\begin{array}{l}\text { Calcium- } \\
\text { magne- } \\
\text { sium }\end{array}$ & $\begin{array}{l}\text { Non- } \\
\text { carbo- } \\
\text { nate }\end{array}$ & & & & \\
\hline 2736290820907.01 & - & 1.1 & -- & - & 287 & 236 & 98 & 383 & 7.7 & 5 & 27.8 \\
\hline 2736550824509.01 & - & -- & -- & - & -- & 720 & -- & 3,170 & - & -- & 27.1 \\
\hline $\begin{array}{l}2739120820546.01 \\
\quad(G D-4)\end{array}$ & - & -- & -- & -- & 369 & 180 & 39 & 410 & 7.2 & -- & 25.6 \\
\hline 2741030822836.01 & - & -- & -- & -- & 1,250 & -- & -- & 1,700 & - & -- & 27 \\
\hline 2742430822115.03 & .5 & -- & -- & 575 & 593 & 450 & 310 & 827 & 7.6 & 0 & -- \\
\hline 2742590824102.02 & 1.1 & -- & -- & 38,200 & 38,200 & 5,800 & 5,600 & 62,000 & - & 5 & 28.4 \\
\hline 2743130821511.01 & .5 & -- & -- & -- & 340 & -- & -- & 451 & - & -- & -- \\
\hline & .7 & 0 & -- & -- & 229 & 165 & -- & 313 & - & -- & -- \\
\hline 2733220822026.01 & - & -- & -- & -- & 382 & -- & -- & 560 & - & -- & 25.0 \\
\hline & .5 & -- & -- & 349 & 371 & 270 & 140 & 551 & 7.5 & -- & 25.0 \\
\hline
\end{tabular}




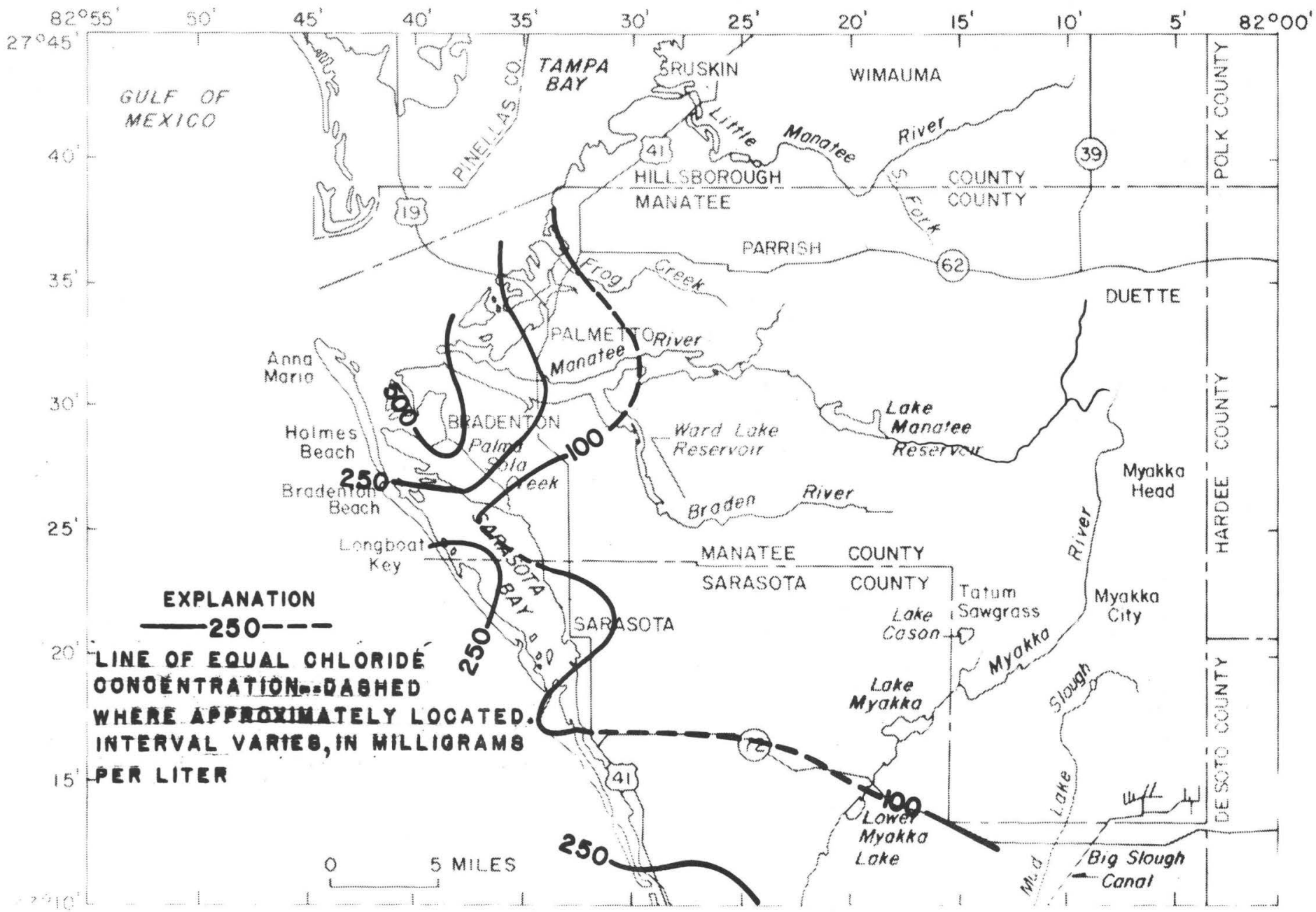

Figure 26a.--Concentrations of chloride in water from the Tampa (upper zone) Limestone. 


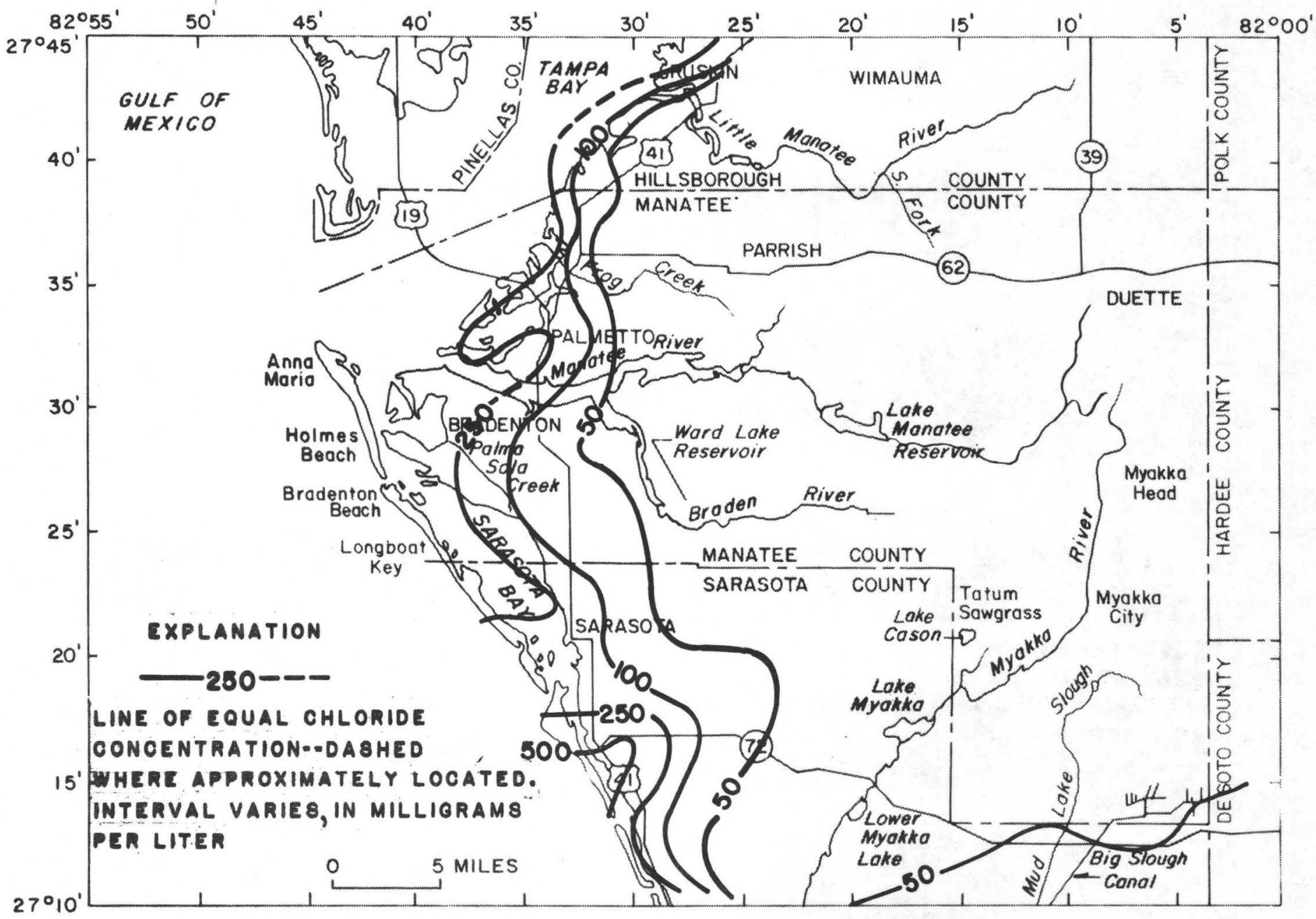

Figure 26b.--Concentrations of chloride in water from the Suwannee-0cala (middle zone) Limestones. 


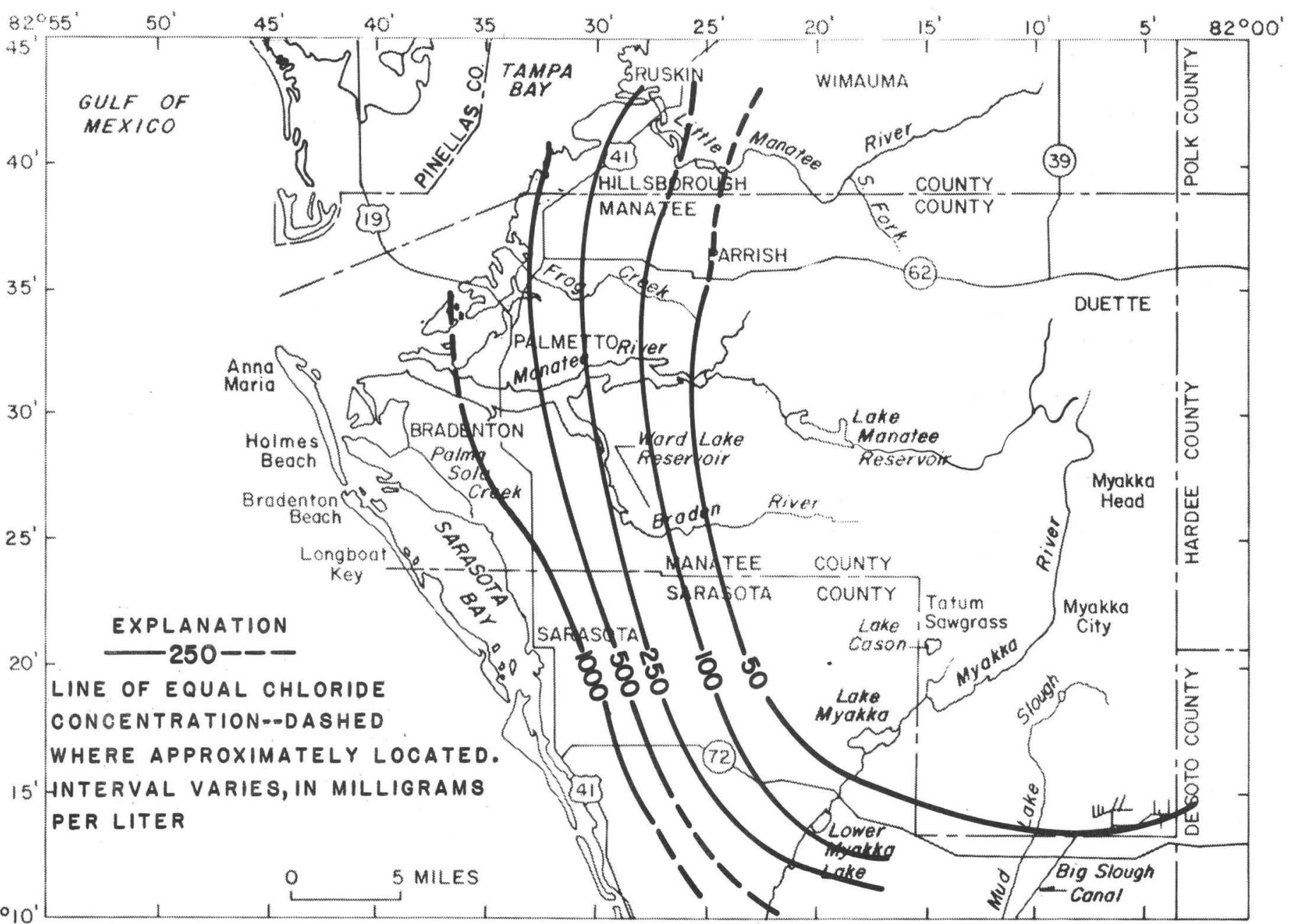

Figure 26c.--Concentrations of chloride in water from the Avon Park (lower zone) Limestone. 
Table 15.--Concentrations of chloride in water from wells open to the Floridan aquifer, $1950-55$ and 1975-76

\begin{tabular}{|c|c|c|c|c|}
\hline \multirow[b]{2}{*}{ We11 number } & \multicolumn{2}{|c|}{$1950-55$} & \multicolumn{2}{|c|}{$1975-76$} \\
\hline & $\begin{array}{c}\text { Date } \\
\text { (month } \\
\text { and year) }\end{array}$ & $\begin{array}{c}\text { Chloride, } \\
\text { C1 } \\
\text { (mg/L) }\end{array}$ & $\begin{array}{c}\text { Date } \\
\text { (month } \\
\text { and year) }\end{array}$ & $\begin{array}{c}\text { Chloride, } \\
\text { C1 } \\
(\mathrm{mg} / \mathrm{L})\end{array}$ \\
\hline 2729020823428.01 & $2-51$ & 60 & $6-76$ & 81 \\
\hline 2726040822345.01 & $11-54$ & 45 & $5-76$ & 20 \\
\hline 2733470823541.01 & $1-54$ & 202 & $6-76$ & 210 \\
\hline 2731340823446.01 & $12-51$ & 875 & $6-76$ & 390 \\
\hline \multirow[t]{2}{*}{2738210823233.01} & $9-51$ & 45 & $5-76$ & 88 \\
\hline & & & $2-75$ & 80 \\
\hline 2731040822407.01 & $3-55$ & 20 & $5-76$ & 17 \\
\hline 2731590823731.01 & $2-51$ & 230 & $5 / 6-76$ & 230 \\
\hline \multirow[t]{2}{*}{2727310824146.02} & $1-55$ & 235 & $6-76$ & 410 \\
\hline & & & $2-75$ & 380 \\
\hline \multirow[t]{2}{*}{2727310824146.01} & $1-55$ & 190 & $6-76$ & 200 \\
\hline & & & $2-75$ & 200 \\
\hline 2727500823803.01 & $1-54$ & 300 & $6-76$ & 770 \\
\hline 2728180824051.01 & $1-54$ & 232 & $6-76$ & 760 \\
\hline 2729310823319.01 & $1-51$ & 50 & $6-76$ & 230 \\
\hline 2729490824040.01 & $9-54$ & 335 & $6-76$ & 84 \\
\hline 2729460823804.01 & $1-53$ & 180 & $6-76$ & 130 \\
\hline 2733430823343.01 & $2-55$ & 208 & $6-76$ & 210 \\
\hline 2725420824051.01 & $3-55$ & 143 & $2-75$ & 180 \\
\hline \multirow[t]{2}{*}{2723240823831.01} & $3-55$ & 280 & $2-75$ & 310 \\
\hline & & & $6-76$ & 320 \\
\hline 2717470821124.01 & $3-52$ & 12 & $4-75$ & 12 \\
\hline 2738210823245.01 & $2-55$ & 50 & $2-75$ & 59 \\
\hline 2736310823140.01 & $7-51$ & 63 & $3-75$ & 54 \\
\hline 2731350823547.01 & $3-51$ & 865 & $6-76$ & 760 \\
\hline 2736290823224.01 & $8-54$ & 70 & $6-76$ & 130 \\
\hline
\end{tabular}

In western Manatee County, there has been little or no change in concentrations of chloride from the middle 1950's to the 1970's in water from wells that penetrate the upper, middle, and lower zones.

Sulfate.--Water in the Floridan aquifer is generally high in sulfate. Concentrations of sulfate range from less than $5 \mathrm{mg} / \mathrm{L}$ to about $900 \mathrm{mg} / \mathrm{L}$, generally increasing with depth and from the northeast towards the west and south (tables 12, 13, and 14 and fig. 27). In the upper zone, high concentrations (greater than $250 \mathrm{mg} / \mathrm{L}$ ) occur only in western and coastal areas (fig. 27).

In water from wells penetrating the middle zone, relatively high concentrations of sulfate extend inland east of Parrish and north of Verna (fig. 27). In water from wells penetrating the upper part of the lower zone, concentration of sulfate generally exceeds $250 \mathrm{mg} / \mathrm{L}$ except in the northeast (fig. 27). 


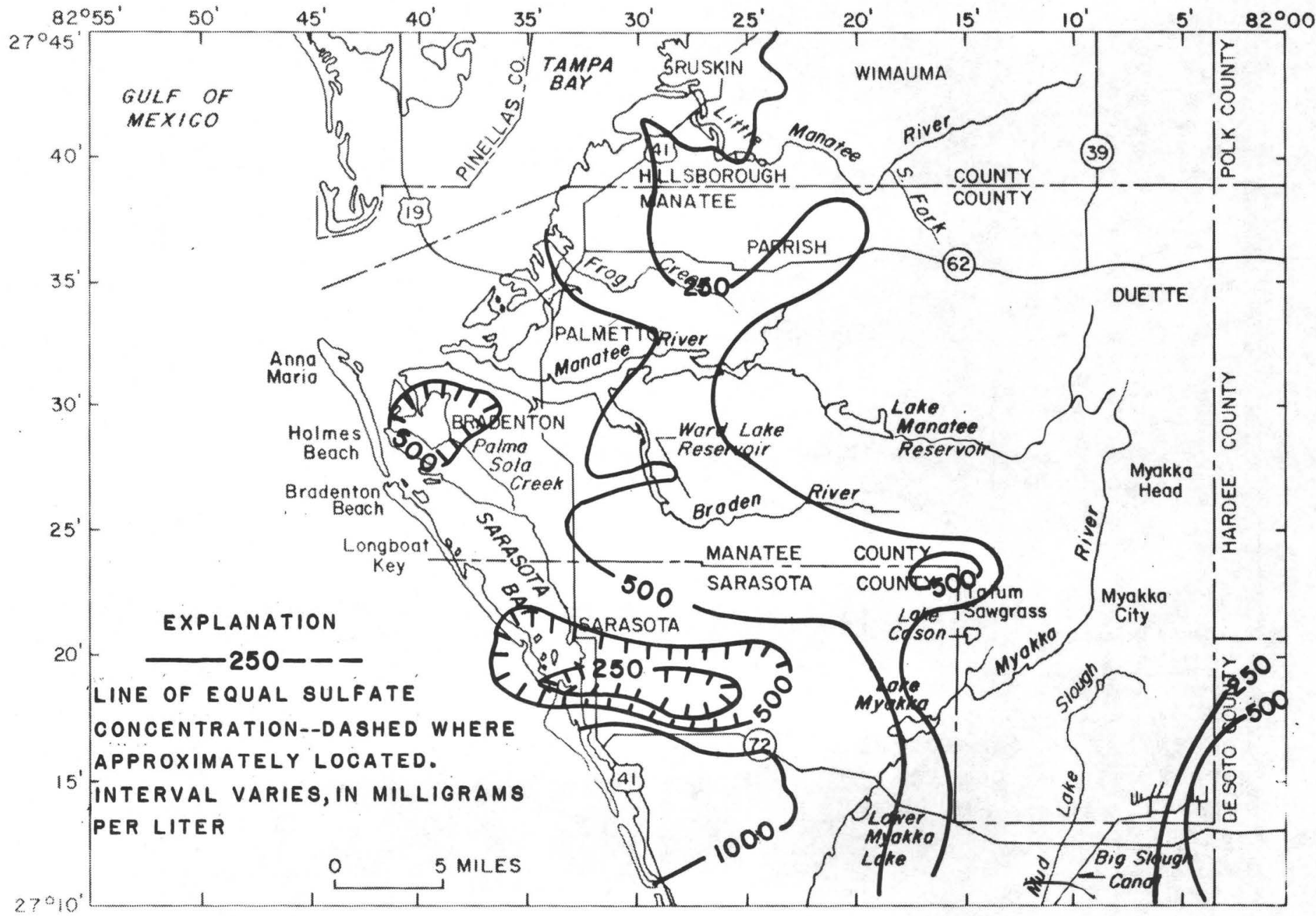

Figure 27b.--Concentrations of sulfate in water from the Suwannee-0cala (middle zone) Limestones. 
In the west, concentrations of sulfate have changed little since the 1950's in water from wells that penetrate the upper zone. Concentrations in water from wells that penetrate the upper and middle zones have increased slightly east of Parrish and near Verna.

Fluoride.--Concentrations of fluoride in water from the Floridan aquifer vary areally and with depth, ranging from less than 0.5 to more than $3.0 \mathrm{mg} / \mathrm{L}$. Highest concentrations are usually in water from the upper zone. In water from wells penetrating the upper, middle, and lower zones, concentrations of fluoride generally increase from the north towards the south and west (fig. 28).

Temperature.--The temperature of the ground water increases with depth on an average gradient of about $1^{\circ} \mathrm{C}$ per 100 feet (Peek, 1958a). The temperature of water from wells penetrating the upper and middle water-bearing zones ranges from about $25^{\circ}$ to $29^{\circ} \mathrm{C}$. The temperature of the water from wells penetrating the lower water-bearing zone ranges from about $25^{\circ}$ to $31^{\circ} \mathrm{C}$.

\section{Saltwater contamination}

Under natural and undisturbed conditions, ground water is discharged to the gulf or to Tampa Bay. Where aquifers are hydraulically connected to the sea, the depth to saltwater is related to the height that freshwater stands above sea level. When freshwater and saltwater are in hydrostatic balance, the Ghyben-Herzberg relation can be used to calculate the approximate depth of the freshwater-saltwater interface. The Ghyben-Herzberg relation as given by Walton (1970) is:

$$
h_{s}=\frac{p_{f}}{p_{s}-p_{f}} h_{f}
$$

where $h_{S}$ is the difference between the elevation of the surface of the ocean and the $\mathrm{s}$ levation of the interface, $\mathrm{p}_{\mathrm{f}}$ is the freshwater density, $\mathrm{p}_{\mathrm{s}}$ is the saltwater density, and $h_{f}$ is the difference between the elevation of the surface of the ocean and the ${ }_{3}$ elevation of the watȩr table or potentiometric surface. If $\mathrm{p}_{\mathrm{s}}=1.025 \mathrm{~g} / \mathrm{cm}^{3}$ and $\mathrm{p}_{\mathrm{f}}=1.000 \mathrm{~g} / \mathrm{cm}^{3}$, then $\mathrm{h}=40 \mathrm{~h}_{\mathrm{f}}$. In September 1975 and 1996, the potentiometric surface of the Floridan aquifer along the coast ranged from about 10 to 20 feet above sea level. Based on the GhybenHerzberg relation, the depth to the saltwater-freshwater interface should range from about 400 to 800 feet below sea level.

Because of tidal action, wet and dry periods, pumpage, and other natural and manmade forces, hydrostatic conditions do not exist in aquifers, and a zone of diffusion exists between saltwater and freshwater. It is the thesis of Cooper (Cooper and others, 1964, p. C1) that when a zone of diffusion exists a cyclic flow is generated in the saltwater from the floor of the sea into the zone of diffusion and back into the sea. This cyclic flow tends to lessen the landward extent to which saltwater moves in the aquifer. Hence, the interface estimated by the Ghyben-Herzberg relation represents a "worst case" or maximum possible landward movement under natural conditions. 


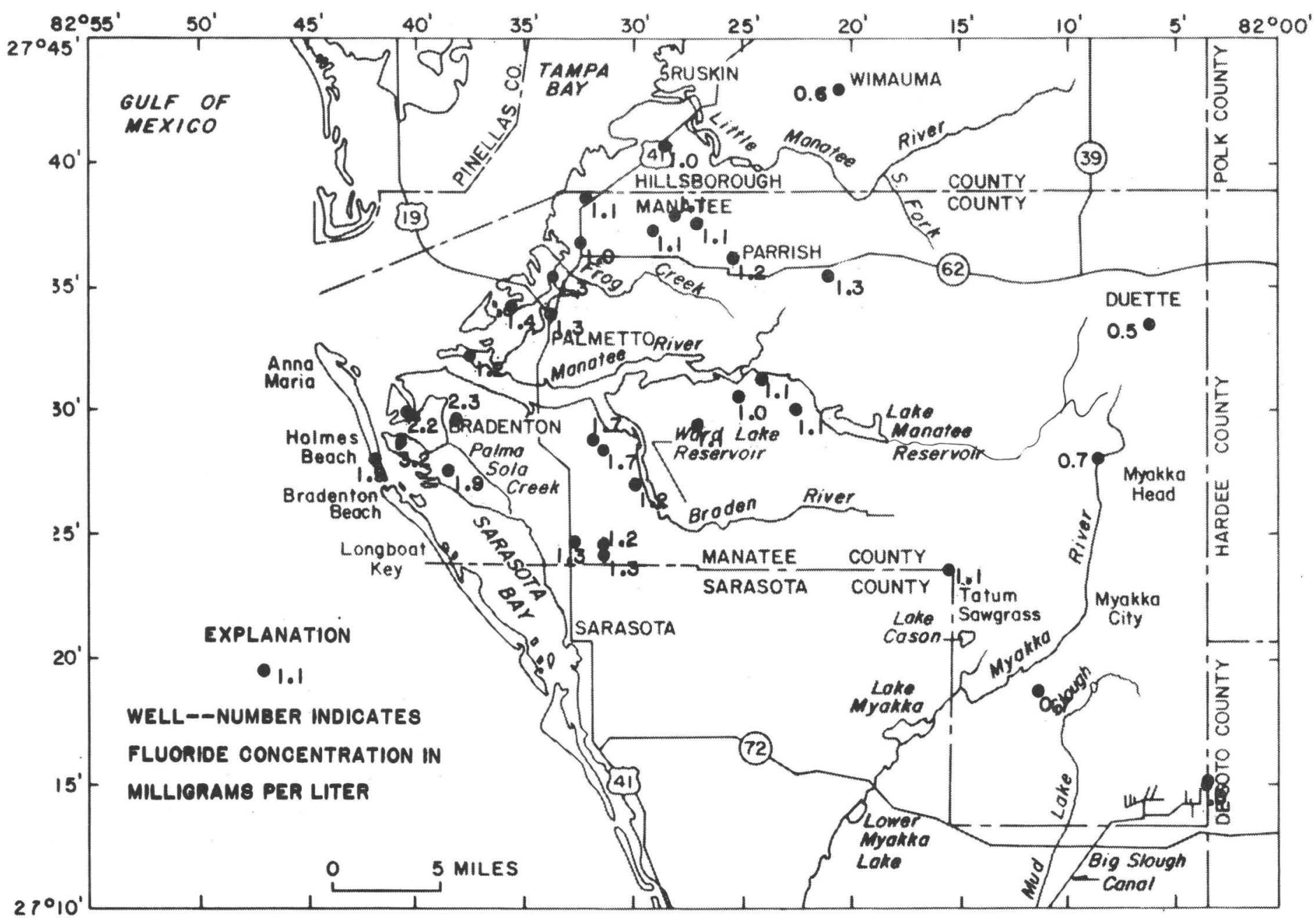

Figure 28a.--Concentrations of fluoride in water from the Suwannee (middle zone) Limestone. 


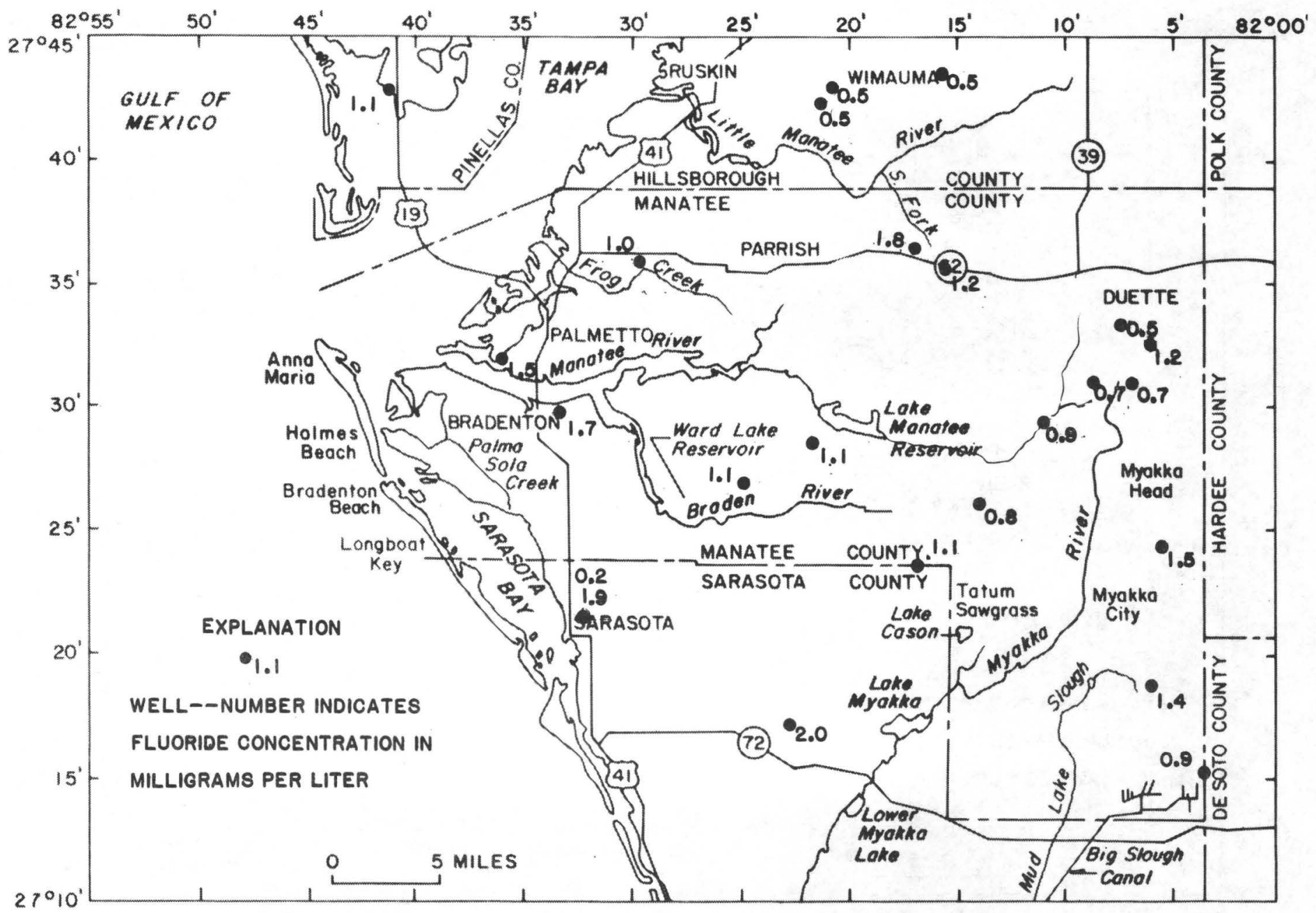

Figure 28b.--Concentrations of fluoride in water trom the Avon Park (lower zone) Limestone. 
Lowering of water levels of aquifers in coastal areas may permit seawater to enter and contaminate the freshwater aquifer (Peek, 1958a). Highly saline water is present in the Floridan aquifer at relatively shallow depths throughout much of coastal Manatee County. In this area, however, the potentiometric surface is sufficiently high to prevent encroachment of water directly from the sea. Thus, Peek (1958a) suggests that extensive occurrences of highly saline water are due to residual seawater that entered the aquifer prior to recent times. These occurrences are probably due to incomplete flushing and dilution of residual seawater by ground water.

Present seasonal fluctuations of the potentiometric surface (1975-76) reduce or reverse the natural hydraulic gradient that slopes towards the sea. The potentiometric surface has fallen below sea level in large areas of the county (fig. 16). Although only slight changes in water quality have been observed, the possibility of saltwater intrusion has increased. Migration of the saltwater front is relatively slow and occurrence of saline water in wells may be years after the decline in the potentiometric surface has reached "serious proportions" (Hem, 1970, p. 313).

Chloride is the major anion of saltwater and moves through aquifers at nearly the same rate as intruding water (Hem, 1970). In areas where other sources of saline contamination do not exist, an increase in chloride concentrations in ground water is an index to saltwater contamination. The concentration of chloride in water from wells that penetrate the upper and middle zones has shown little variation since the early and middle 1950's.

During 1972-74, chloride concentrations of water from an 800-foot deep irrigation well, about 6 miles southwest of Ruskin that penetrated the lower zone, increased from 260 to $980 \mathrm{mg} / \mathrm{L}$. Chloride concentrations in water from nearby wells ranged from 25 to $50 \mathrm{mg} / \mathrm{L}$. These wells ranged in depth from 250 to 600 feet and penetrated the upper and middle zones (Duerr, 1974).

From 1962 to 1976, concentrations of chloride in water from a deep industrial supply well (2729130823304.01) in Bradenton increased from 200 to 670 $\mathrm{mg} / \mathrm{L}$. The 1,060-foot deep well penetrated the lower zone. In a nearby well (2729310823319.01), water samples were collected at depths of 470,600, and 930 feet below sea level. Chloride concentrations were 230,88 , and $61 \mathrm{mg} / \mathrm{L}$, respectively. The well penetrated the upper and middle zones.

\section{WATER-RESOURCES DEVELOPMENT}

\section{Surface Water}

Water from the Manatee River at Lake Manatee Reservoir (fig. 29) and from its principal tributary, the Braden River at Ward Lake Reservoir, are used for public supplies. Water from the Little Manatee River is used for makeup water for a thermoelectric powerplant and cooling pond.

Discharge of the Manatee River is regulated by gates in an earthen dam at Lake Manatee Reservoir about 29 miles upstream from the river's mouth. The reservoir impounds water from a drainage area of $123 \mathrm{mi}^{2}$. At a pool elevation of 


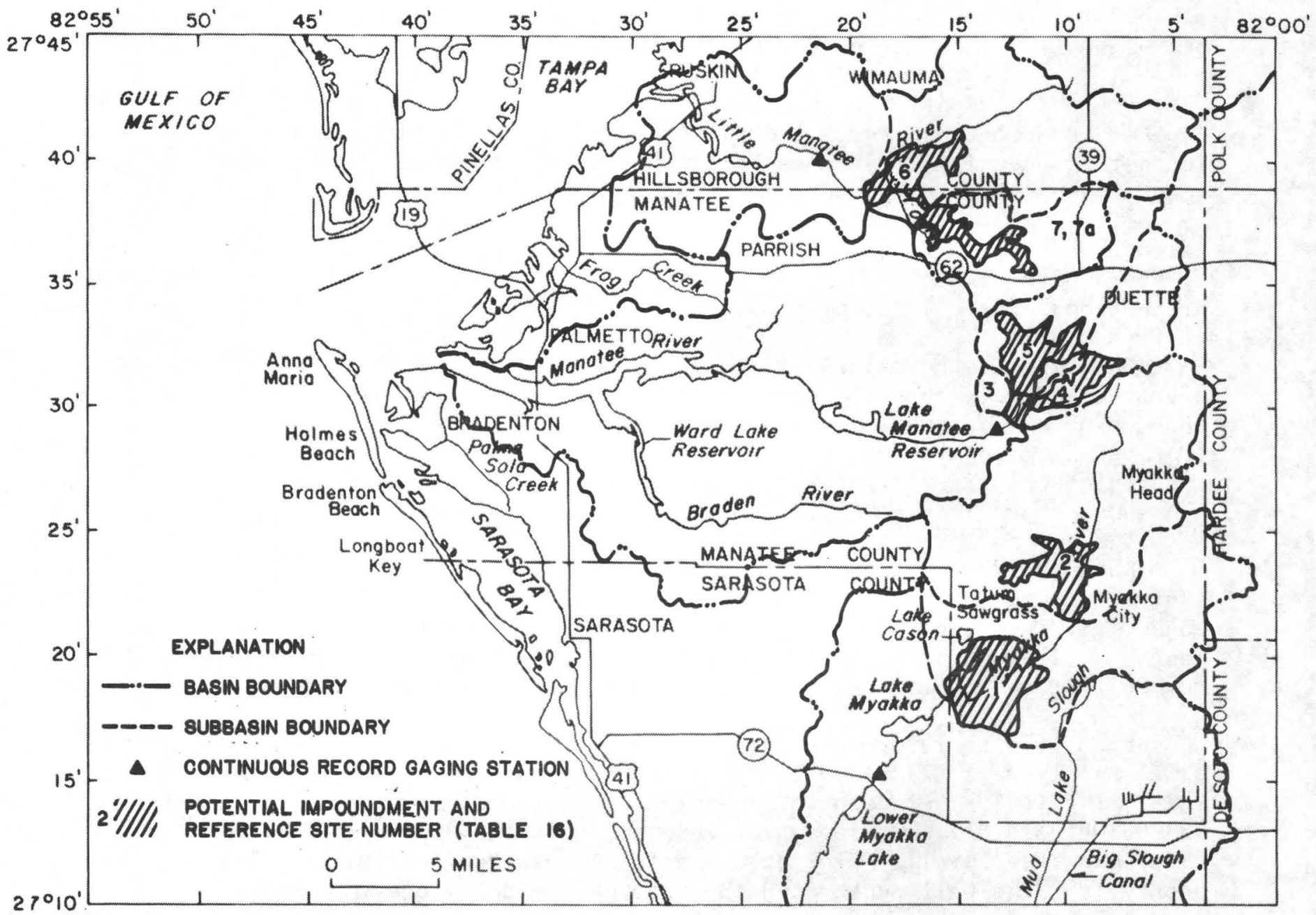

Figure 29.--Locations of potential impoundments, existing reservoirs, and stream-gaging stations, Manatee County and adjacent areas. 
40 feet above sea leve1, the reservoir has a surface area of about 1,850 acres and a storage capacity of about $7,000 \mathrm{Mgal}$ (fig. 30). In 1977, an average of $19.1 \mathrm{Mgal} / \mathrm{d}$ was pumped from the reservoir. Peak day pumpage was $27.6 \mathrm{Mgal} / \mathrm{d}$.

The low-flow characteristics of streams often control their value and utilization as a source of water. Since draft rates often exceed minimum flow of the streams, storage is required to meet expected demands. The amount of storage required is dependent upon the draft rate, magnitude and frequency of annual low flows, and the length of periods of low flow. The magnitude and frequency of annual low flows for selected periods are presented in table 5 (Myakka River near Sarasota), table 6 (Manatee River near Bradenton), table 7 (Manatee River near Myakka Head), and table 8 (Little Manatee River near Wimauma).

Draft-storage frequency relations for the Lake Manatee Reservoir (fig. 31) indicate that at a 5 percent risk of inadequate storage (once in 20 years) the present reservoir could supply a continuous draft of about $38 \mathrm{Mgal} / \mathrm{d}$, assuming a full reservoir at the beginning of the period and usable storage of 6,000 Mgal (storage between the 25- and 40-foot pool elevations). By increasing the pool elevation to 50 feet and usable storage to 15,000 Mgal, as has been proposed, the reservoir could supply a continuous draft of about $74 \mathrm{Mgal} / \mathrm{d}$ at a 5 percent risk of being inadequate.

Ward Lake Reservoir has a surface area of 57.6 acres and impounds water from a drainage area of $59.5 \mathrm{mi}^{2}$. The elevation of the crest of the control structure is about 4.2 feet above sea leve1. The storage capacity of the reservoir is about $585 \mathrm{Mgal}$. In 1977, the city of Bradenton pumped an average of $4.0 \mathrm{Mgal} / \mathrm{d}$ from the reservoir. Peak day pumpage was $5.25 \mathrm{Mgal} / \mathrm{d}$. At the demand rate of $4.0 \mathrm{Mgal} / \mathrm{d}$, the reservoir has about a 40 percent risk of being inadequate (Smith and Gillespie Engineers, Inc., 1971).

Draft-storage frequency relations at the continuous record gaging stations for Myakka River near Sarasota, Manatee River near Myakka Head, and Little Manatee River near Wimauma (fig. 29) are shown in figures 32, 33, and 34, respectively. These relations indicate the amount of storage needed to maintain continuous drafts with 10 - and 20-year risks of being inadequate. For example, to provide a continuous draft rate of $50 \mathrm{Mgal} / \mathrm{d}$ at a 5 percent risk of failure (once in 20 years), an estimated storage of about 11,000 Mgal is required at Myakka River near Sarasota (fig. 32), 11,000 Mgal at Manatee River near Myakka Head (fig. 33), and 8,400 Mgal at Little Manatee River near Wimauma (fig. 34 ).

Seven sites have been identified that may be suitable for impoundment of water. Two sites are in the Myakka River basin, three sites in the Manatee River basin, and two in the Little Manatee River basin (fig. 29). The sites, their approximate drainage areas, surface areas, and storage (not adjusted for evaporation) at selected stages, are listed in table 16. The reservoirs would be small and have surface areas ranging from 0.140 to $0.97 \mathrm{mi}^{2}$ and storage ranging from 3,100 to $15,000 \mathrm{Mgal}$.

\section{Ground Water}

Development of ground water is largely dependent upon the hydraulic properties of aquifers and confining beds and quality of water. The estimated range of selected hydraulic properties is presented in table 17. 




Figure 30.--Surface area and storage capacity of Lake Manatee Reservoir. 


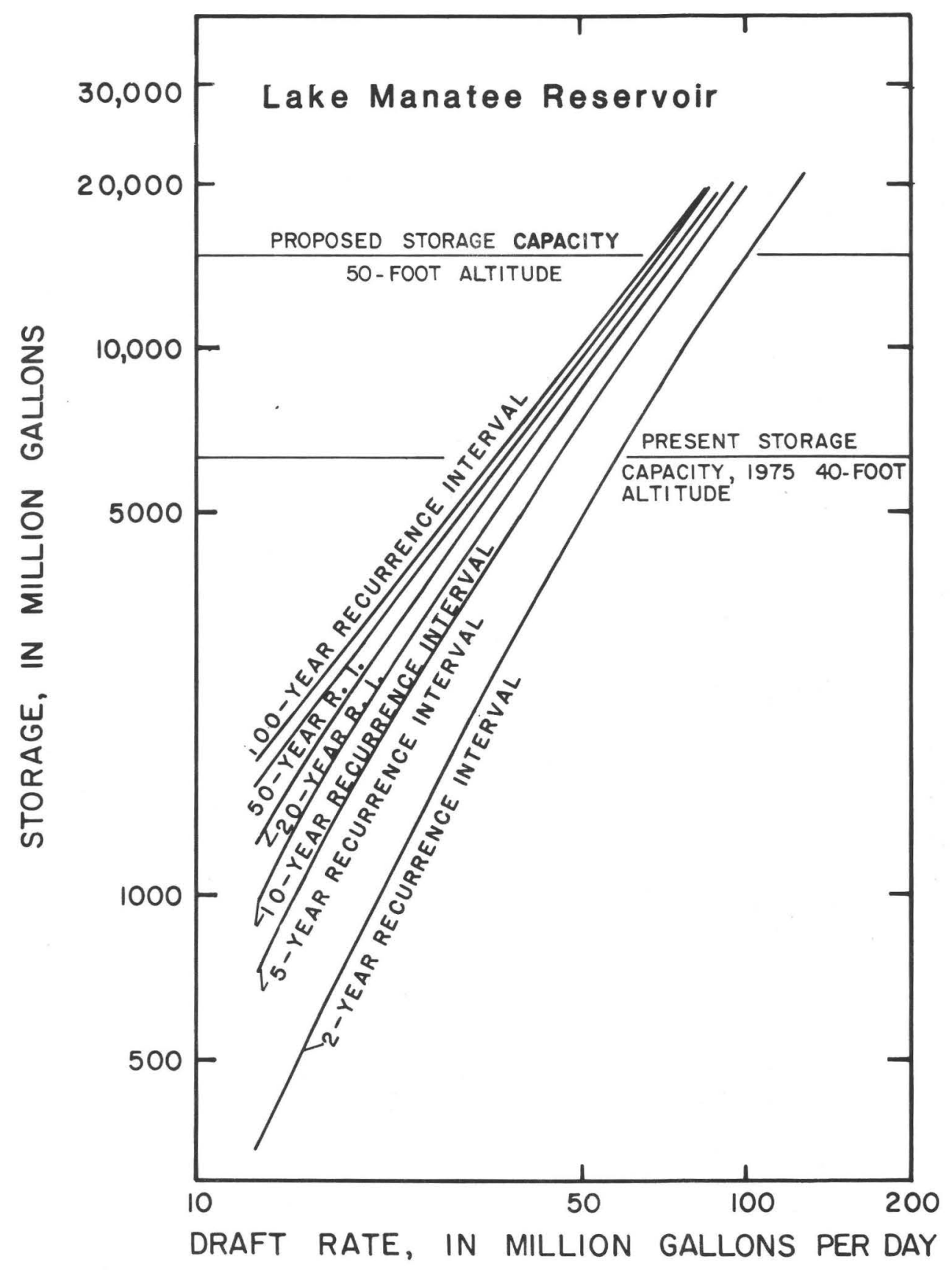

Figure 31.--Draft-storage frequency relations for Lake Manatee Reservoir. 


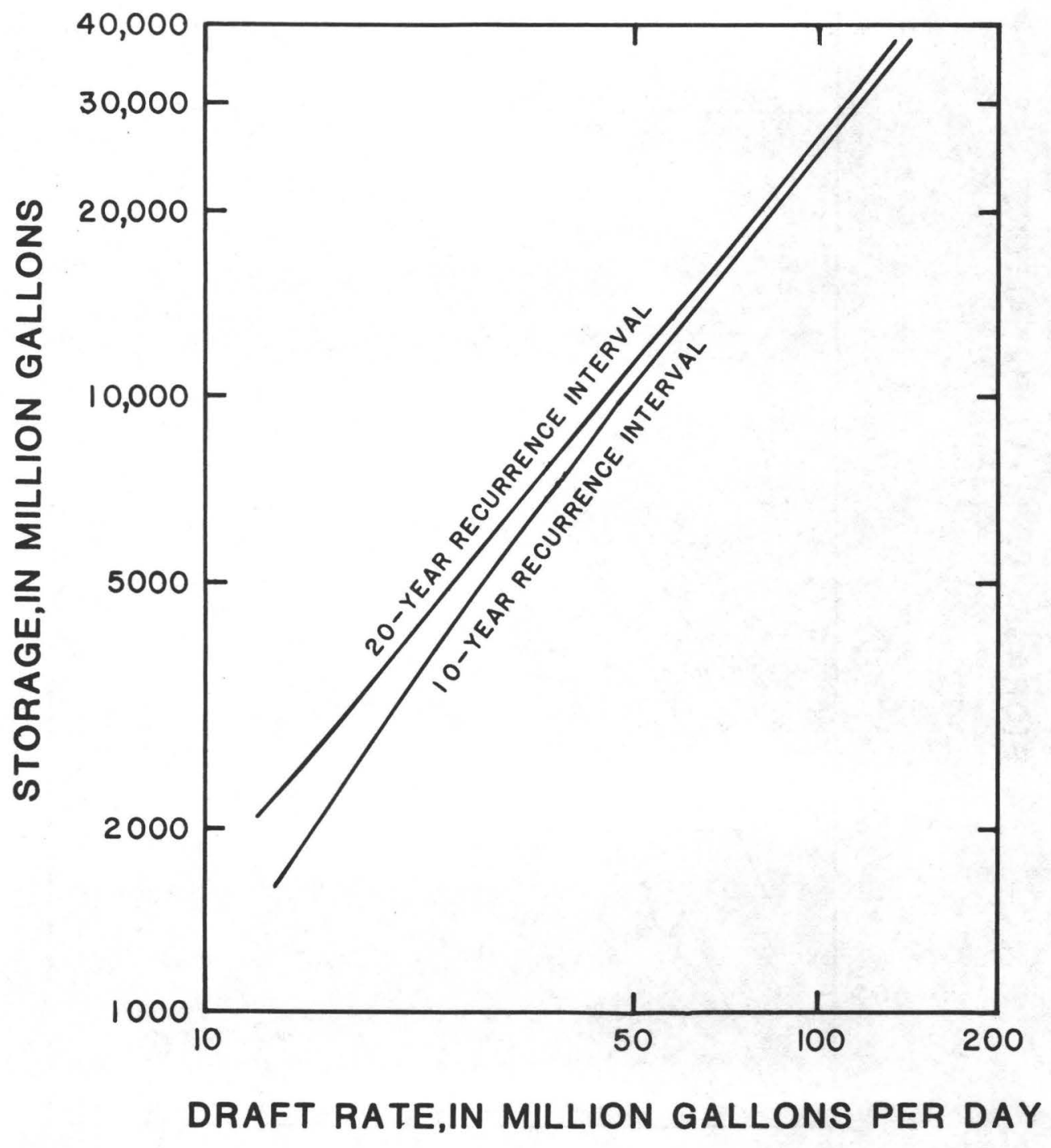

Figure 32.--Draft-storage frequency relations for Myakka River near Sarasota. 


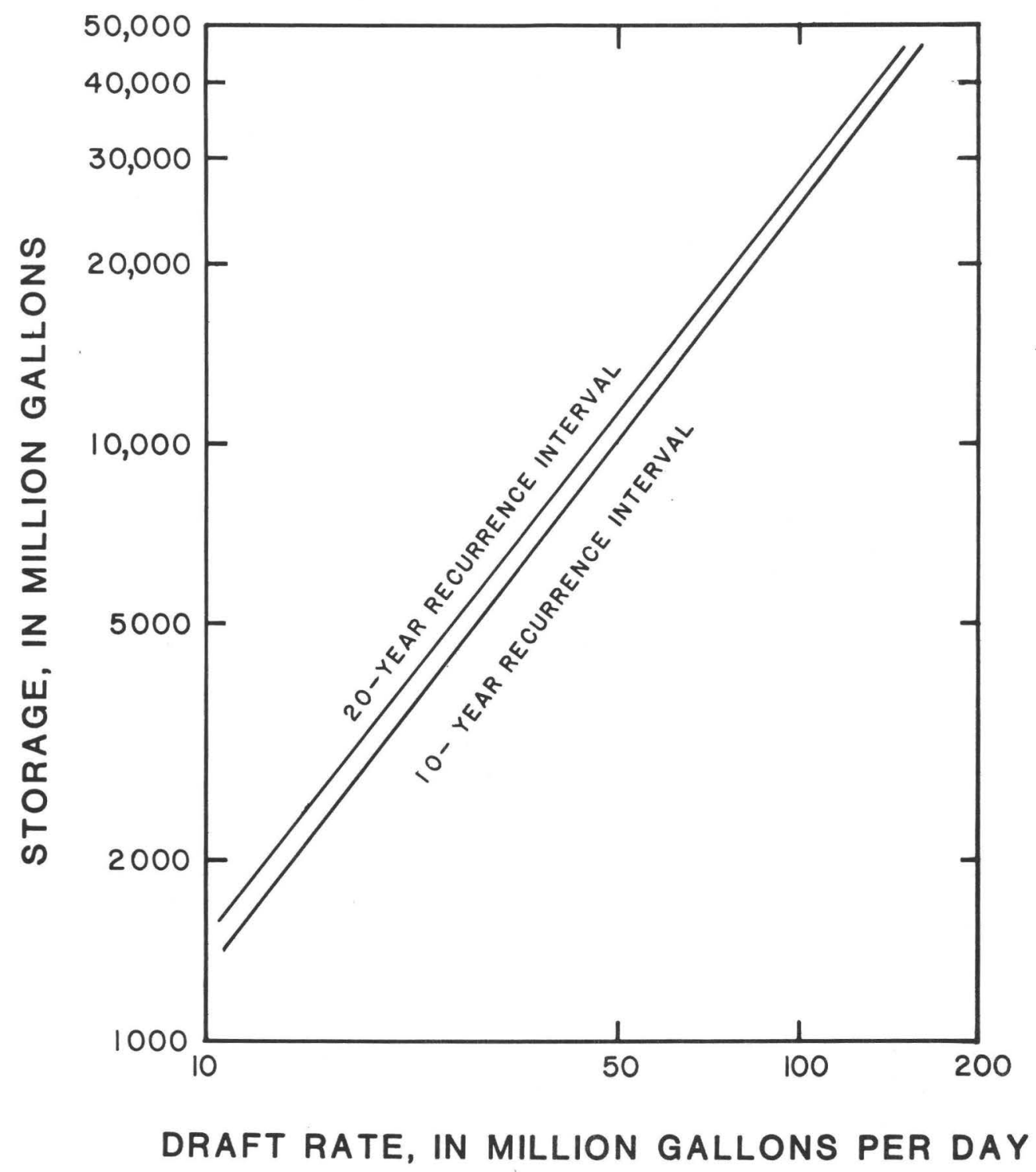

Figure 33.--Draft-storage frequency relations for Manatee River near Myakka Head. 


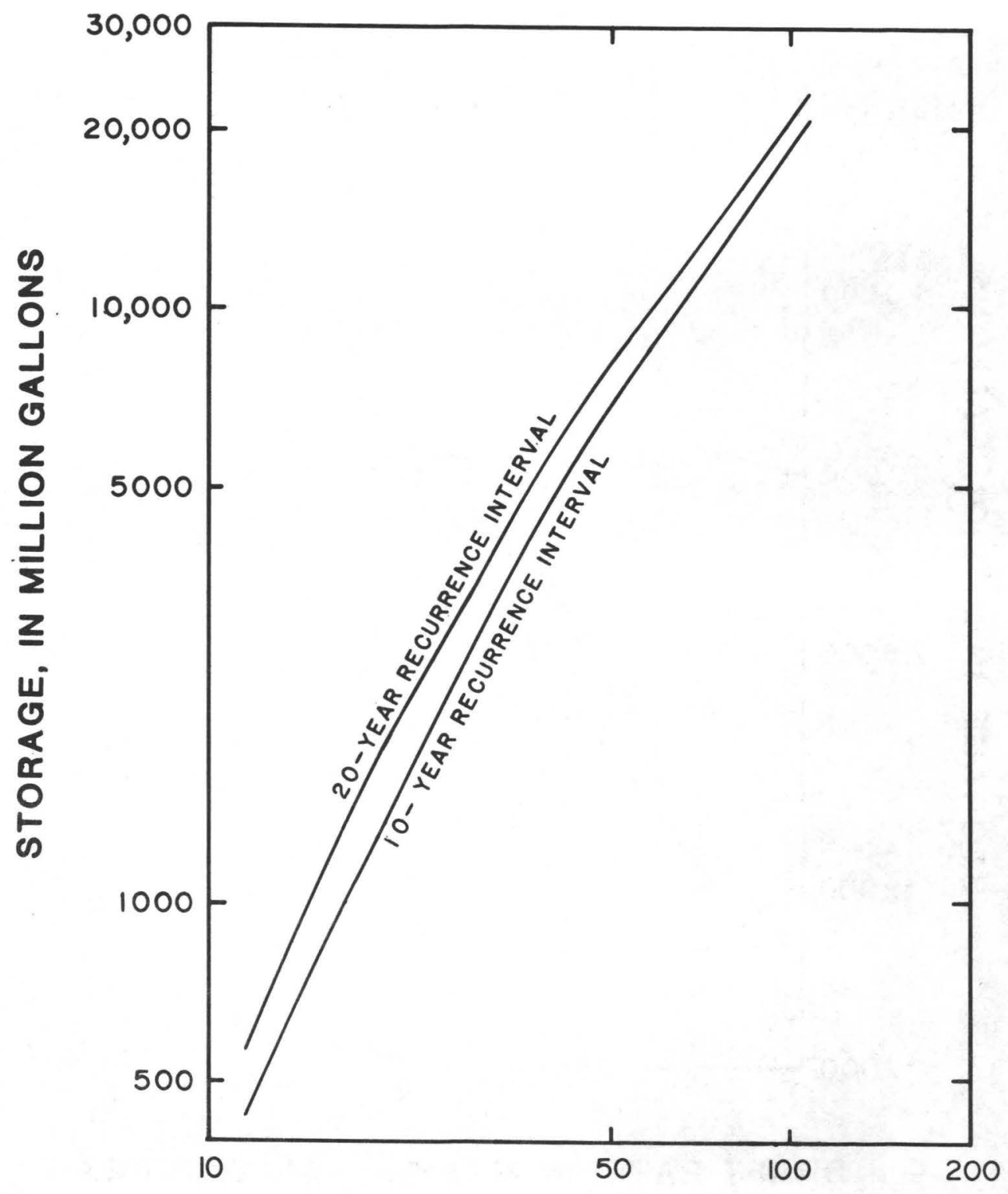

DRAFT RATE, IN MILLION GALLONS PER DAY

Figure 34.--Draft-storage frequency relations for Little Manatee River near Wimauma. 
Table 16.--Potential impoundment sites in and near Manatee County

\begin{tabular}{|c|c|c|c|c|c|}
\hline $\begin{array}{l}\text { Reference } \\
\text { number } \\
\text { (fig. 29) }\end{array}$ & Name & $\begin{array}{l}\text { Impoundment } \\
\text { surface area } \\
\qquad\left(\mathrm{mi}^{2}\right)\end{array}$ & $\begin{array}{l}\text { Stage } \\
\text { (feet, sea } \\
\text { leve1) }\end{array}$ & $\begin{array}{l}\text { Approximate } \\
\text { drainage } \\
\text { area } \\
\left(\mathrm{mi}^{2}\right)\end{array}$ & $\begin{array}{l}\text { Storage } \\
\text { (Mgal) }\end{array}$ \\
\hline 1 & Tatum Sawgrass & 6.5 & 24 & 174 & 8,800 \\
\hline 2 & $\begin{array}{l}\text { Myakka River near } \\
\text { Myakka City }\end{array}$ & 7.9 & 50 & 97 & 13,000 \\
\hline 3 & $\begin{array}{l}\text { Manatee River } \\
\text { near Myakka Head }\end{array}$ & 2.4 & 80 & 63 & 5,200 \\
\hline 4 & $\begin{array}{l}\text { East Fork Manatee } \\
\text { River }\end{array}$ & 1.8 & 90 & 28 & 3,100 \\
\hline 5 & $\begin{array}{l}\text { North Fork } \\
\text { Manatee River }\end{array}$ & 1.9 & 90 & 33 & 3,200 \\
\hline 6 & $\begin{array}{l}\text { Little Manatee } \\
\text { River near } \\
\text { Wimauma }\end{array}$ & 7.1 & 50 & 140 & 15,000 \\
\hline 7 & $\begin{array}{l}\text { South Fork Little } \\
\text { Manatee River }\end{array}$ & 1.5 & 75 & 39 & 4,400 \\
\hline $7 a$ & $\begin{array}{l}\text { South Fork Little } \\
\text { Manatee River }\end{array}$ & 4.1 & 95 & 38 & 14,000 \\
\hline
\end{tabular}

Surficial Aquifer

The surficial aquifer is generally undeveloped as a source of water. Small volumes of water are used for domestic, lawn irrigation, or stock watering. Most wells that tap the surficial aquifer have small diameters and usually yield less than $50 \mathrm{gal} / \mathrm{min}$ of water. Most wells are finished as open holes; some are screened.

The surficial aquifer has the greatest potential as a dependable water supply because it is readily recharged by precipitation. The potential varies as the physical characteristics of the aquifer and the conditions of recharge to and discharge from the aquifer vary. It also has the greatest potential for contamination from surface sources. The aquifer can be developed by means of conventional wells, collector wells, and tile drains.

Collector wells provide an effective means of developing shallow wells in sand, gravel, and shell deposits. Collector wells consist of a cylindrical caisson plugged at the bottom. One or more tiers of horizontal perforated pipe (laterals) are connected to the caisson wall (Walton, 1970). The well has an advantage in that it creates a cone of depression of large radius and of small depth (Wolansky, 1978). 
Table 17.--Estimated hydraulic properties of aquifers and confining beds

[Modified from R. M. Wolansky, U.S. Geological Survey, Tampa, Florida (written commun., 1977)]

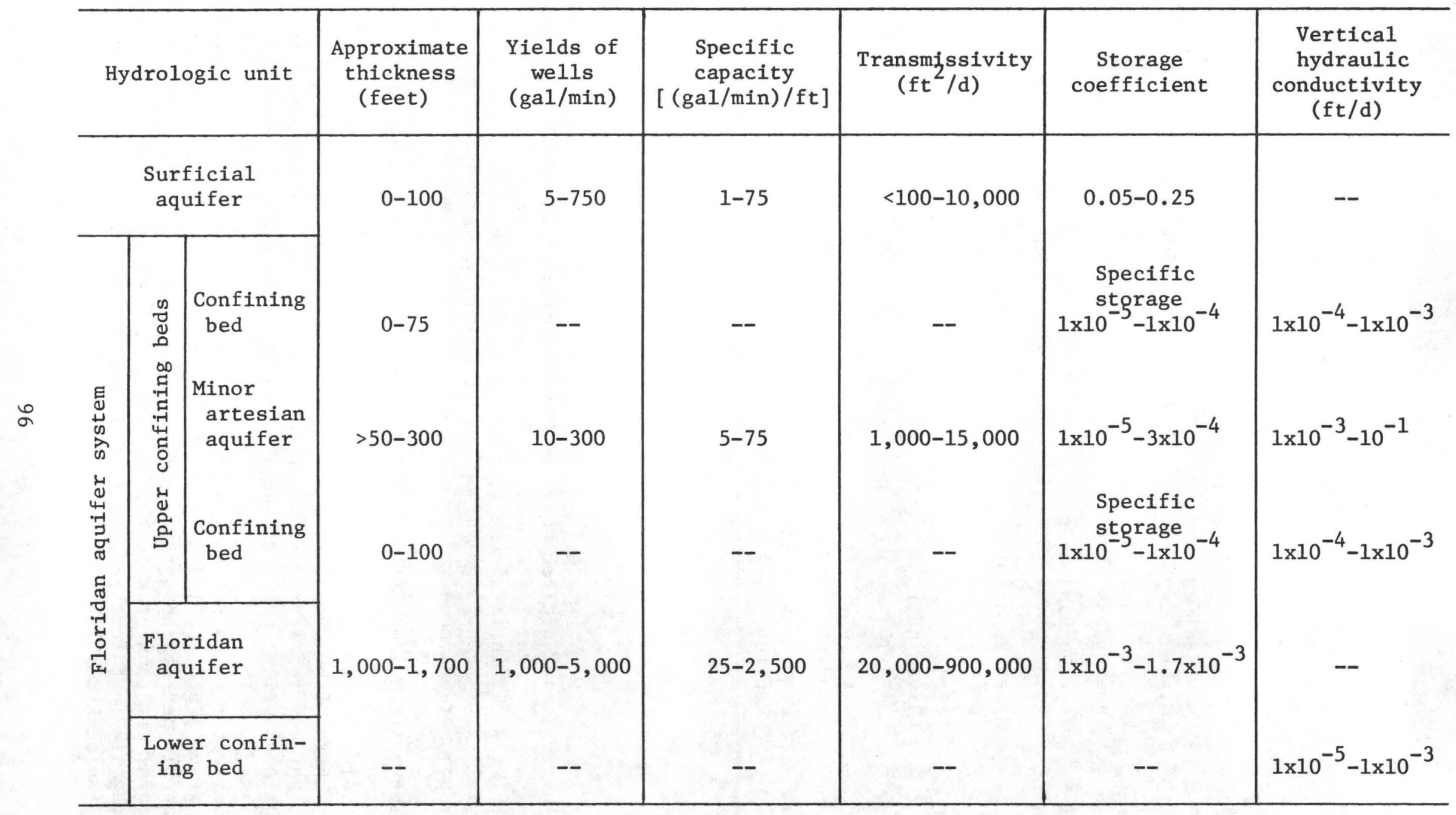


Tile drains are primarily used to drain agricultural land but provide a method of developing water supplies in areas where the surficial aquifer is thin and transmissivity is low. In northwestern Hillsborough County, Sinclair (1977) showed that an array of subsurface tile drains, about 1,000 feet long and 5 feet below land surface, produced about $19 \mathrm{gal} / \mathrm{min}$ from a 3-acre area.

Minor Artesian Aquifer

Water from the minor artesian aquifer is primarily used for domestic supply in Manatee County. Other uses include stock watering, irrigation, and small public supplies. Most irrigation wells that penetrate the Floridan aquifer are also open to the minor artesian aquifer.

We11s open to the minor artesian aquifer are generally finished as open hole. Small diameter wells (2 inches) may produce 25 to $30 \mathrm{gal} / \mathrm{min}$. Large diameter wells (6 inches or larger) that fully penetrate the aquifer usually yield more than $200 \mathrm{gal} / \mathrm{min}$. The aquifer is most productive in the western and southern parts of Manatee County, but yields little water in the northeastern part. The minor artesian aquifer is a major source of water for the Verna well field in northeast Sarasota County (fig. 1).

High concentrations of dissolved solids, chloride, and sulfate (more than 500,250 , and $250 \mathrm{mg} / \mathrm{L}$, respectively) limit its potential for development in the coastal and southern parts of the county. Elsewhere, the quality of the water is suitable for most purposes.

Floridan Aquifer

The Floridan aquifer is the principal source of ground water in Manatee County. Water from the aquifer is primarily used for irrigation. Minor amounts are used for industrial purposes, air conditioning, and public and domestic supplies. The aquifer was a major source for public supply in Manatee County before development of surface-water sources.

Depending on the thickness penetrated and diameter of the well, the Floridan aquifer yields from less than $500 \mathrm{gal} / \mathrm{min}$ for wells 6 inches or less in diameter and only partially penetrating the aquifer to more than 5,000 $\mathrm{gal} / \mathrm{min}$ for wells 8 inches or more in diameter and fully penetrating the aquifer. Most wells are finished as open hole and are usually cased to the first consistent rock unit. In eastern and southern Manatee County, the depth of casing generally ranges from less than 200 feet to more than 500 feet below land surface. The wells range in depth from about 500 to 1,500 feet, depending on the quality and quantity of water needed. In the western and coastal parts of the county, casing depths generally range from less than 50 to about 200 feet below land surface. Well depths are generally less than 700 feet, primarily because of poor water quality at depth.

Hydrologic properties that limit development of an aquifer system are transmissivity and storage. Leakage of water to a confined aquifer during pumping has a bearing on the time when an aquifer reaches equilibrium and maximum drawdown. 
To determine the effects of development, hydrologic properties were used to estimate water-level drawdowns. Time-drawdown curves and distance-drawdown curves were developed using a transmissivity of $100,000 \mathrm{ft}^{2} / \mathrm{d}$, a sţorage coefficient of $1 \times 10^{-3}$, a leakance $\left(\mathrm{K}^{\prime} / \mathrm{b}^{\prime}\right)$ of $5.3 \times 10^{-6}(\mathrm{ft} / \mathrm{d}) / \mathrm{ft}\left[4 \times 10^{-5}(\mathrm{gal} / \mathrm{d}) / \mathrm{ft}^{3}\right]$, and a pumpage rate of $2,000 \mathrm{gal} / \mathrm{min}$ (fig. 35). As shown, after 100 days of pumping a single well at 2,000 gal/min, drawdowns of about 3 feet and 1 foot would occur at distances of 1,000 and 10,000 feet from the we11, respectively. Assuming steady-state conditions when the aquifer system is in equilibrium, maximum drawdowns would be $5.9,4.5$, and 3.1 feet at distances of 10,100 , and 1,000 feet, respectively (fig. 35).

Long-range projections of water use in west-central Florida indicate that substantial increases in withdrawals will occur for municipal supplies, irrigation, and phosphate mining (Wilson, 1977b). The potential effects of proposed phosphate mining in the county on the potentiometric surface of the Floridan aquifer are discussed by Wilson (1977b). Preliminary results indicated that maximum simulated drawdown in Manatee County would be about 15 feet by 1985 and about 14 feet by 2000 .

The combined effects of withdrawal from the Floridan aquifer for municipal supplies, irrigation, and phosphate mining from 1976 to 2000 are discussed by Wilson and Gerhart (1979). The projected potentiometric surface in May 2000 ranges from about 10 feet below sea level in the central part of the county to about 20 feet above sea level in the southeast (fig. 36). Projected declines in the potentiometric surface from May 1976 to May 2000 range from about 5 feet along the coast to 30 feet in the northeast. By October 2000, the projected altitude of the potentiometric surface will range from about 10 feet above sea level along the coast to 30 feet in the northeastern part of the county (fig. 37). Projected declines from November 1976 to October 2000 range from zero along the coast to more than 20 feet in the northeast. The effect of the projected declines on surface-water supplies will probably be minimal because of the relatively thick confining beds separating the surficial aquifer from the Floridan aquifer.

The principal chemical constituents that determine the potability of water in the Floridan aquifer are chloride, sulfate, and dissolved solids. Figure 38 shows areas where concentrations of chloride, sulfate, or dissolved solids exceed 250,250 , and $500 \mathrm{mg} / \mathrm{L}$, respectively, in water from wells open to the waterbearing zones of the Suwannee Limestone-Ocala Limestone (middle water-bearing zone) and the Avon Park Limestone (lower water-bearing zone). Water supplies from these zones that would require minimum treatment occur only in the northeastern part of the county.

\section{WATER USE}

A knowledge of types and distribution of present water use is needed in evaluating the water resources. Background information on water use was provided by statewide water-use surveys in 1970 and 1975 (Pride, 1973; Leach, 1977). Results from these surveys are summarized in table 18. In 1975, an estimated $45 \mathrm{Mgal} / \mathrm{d}$ of surface water and $31 \mathrm{Mgal} / \mathrm{d}$ of ground water were used in Manatee County. The principal uses of surface water were for public supply and for cooling water for thermoelectric power generation. Ground water was primarily used for irrigation. 

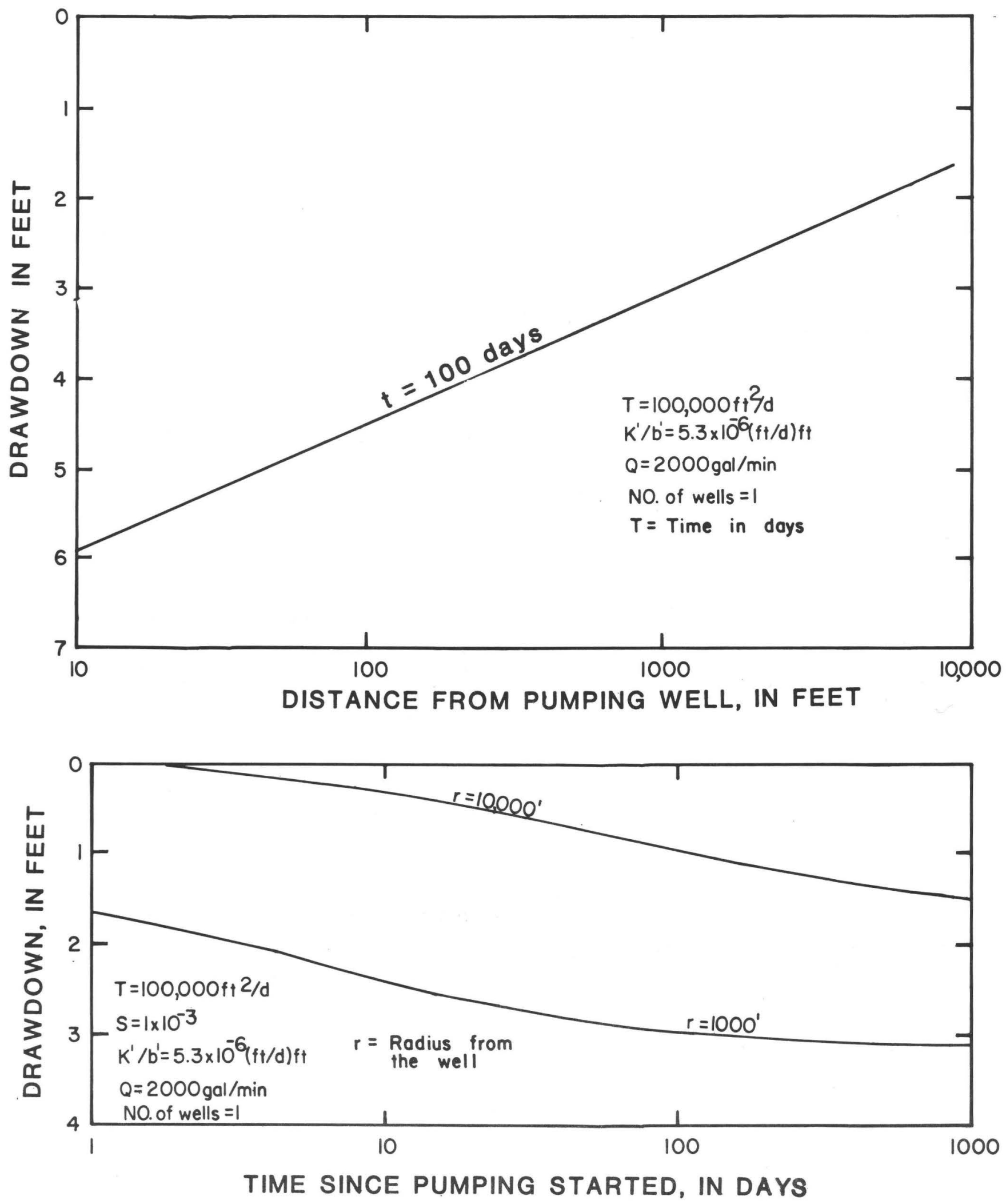

Figure 35.--Steady-state distance-drawdown and time-drawdown curves for the Floridan aquifer. 


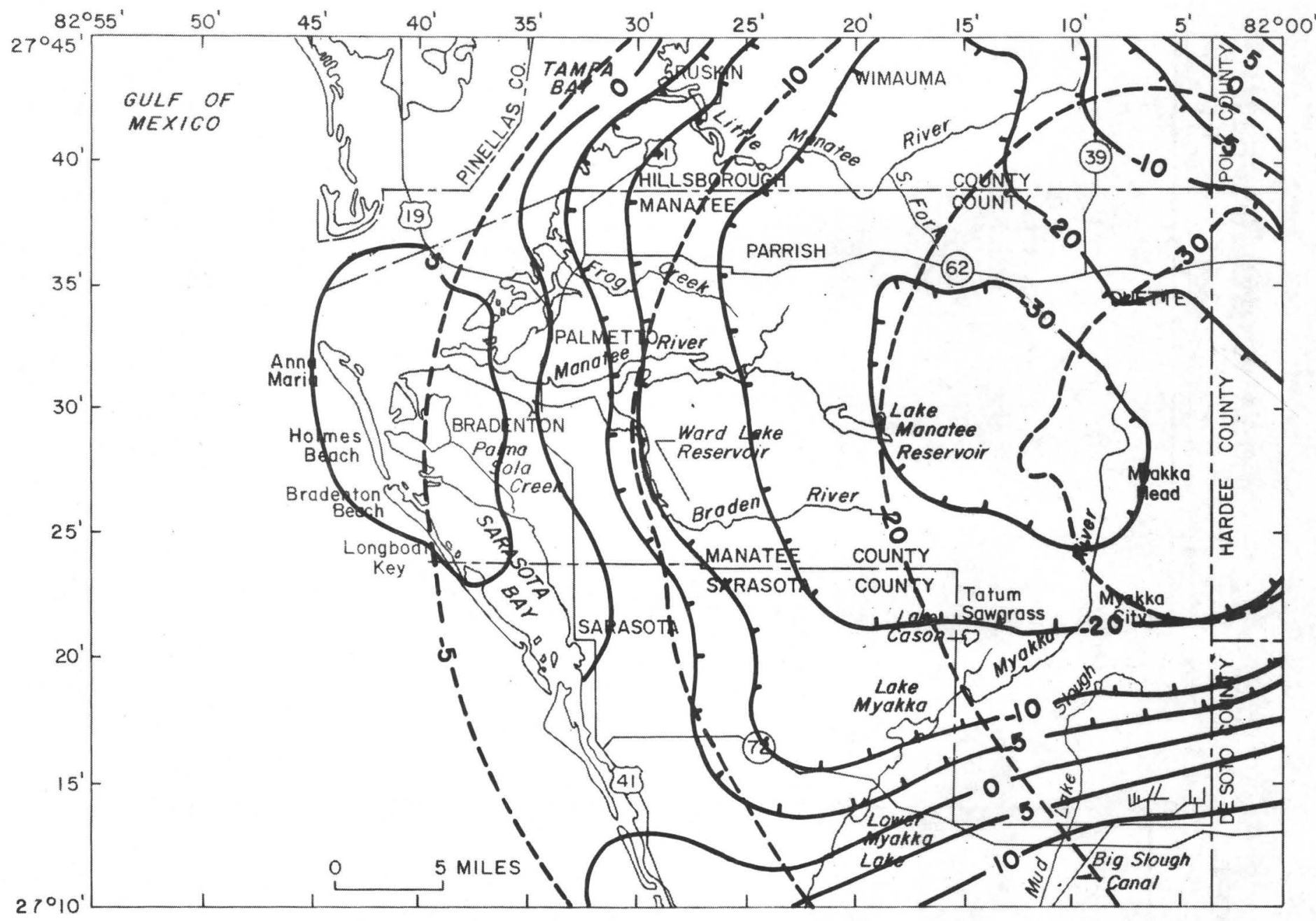

EXPLANATION

- 5 - POTENTIOMETRIC CONTOUR--SHOWS ALTITUDE AT WHICH WATER LEVEL WOULD HAVE STOOD IN TIGHTLY CASED WELLS. CONTOUR INTERVAL 5 AND IO FEET. DATUM IS NGVD OF 1929.

- 5 - - LINE OF EQUAL WATER-LEVEL DECLINE-- INTERVAL 5 AND 10 FEET

Figure 36.--Projected potentiometric surface of the Floridan aquifer, May 2000, and decline in the potentiometric surface, May 1976 to May 2000 (modified from Wilson and Gerhart, 1979). 


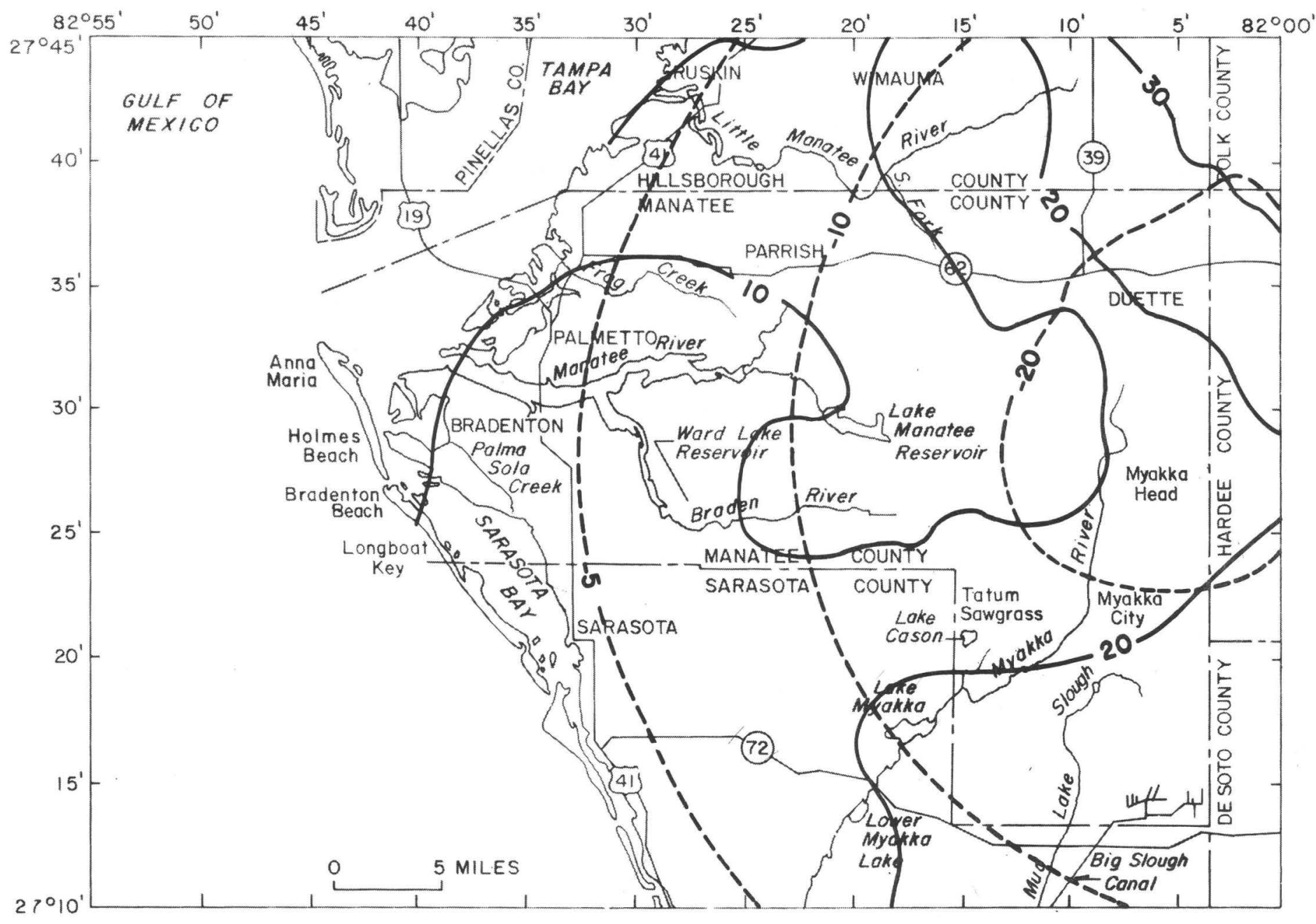

EXPLANATION

- IO- POTENTIOMETRIC CONTOUR--SHOWS ALTITUDE AT WHICH WATER LEVEL WOULD HAVE STOOD IN TIGHTLY CASED WELLS. CONTOUR INTERVAL 5 AND 10 FEET. DATUM 18 NOVD OF 1929

- -10- - LINE OF EQUAL WATER-LEVEL DECLINE-- INTERVAL 5 AND 10 FEET

Figure 37.--Projected potentiometric surface of the Floridan aquifer, October 2000, and decline in the potentiometric surface, November 1976 to October 2000 (modified from Wilson and Gerhart, 1979). 


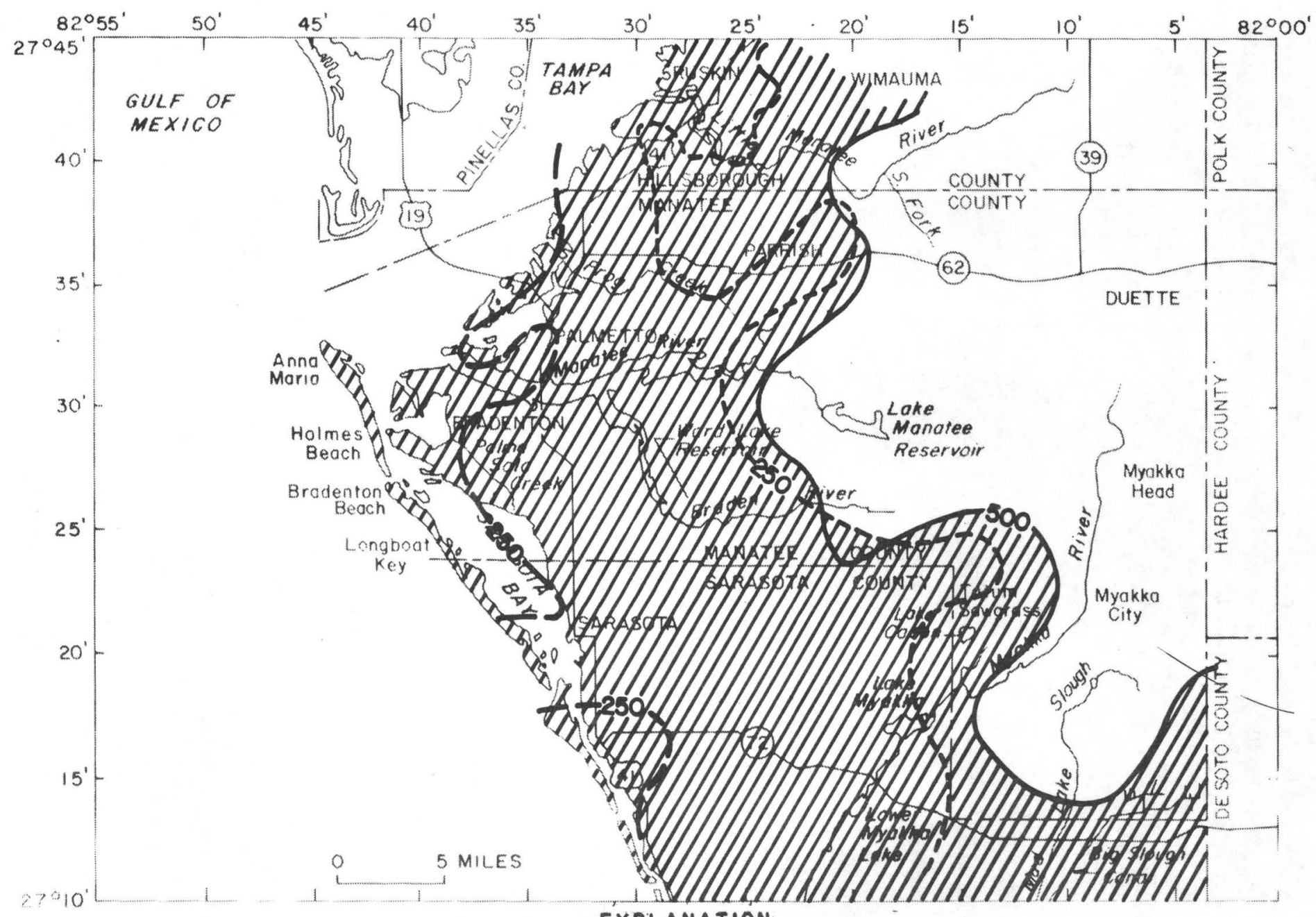

EXPLANATION

- 500- LINE OF EQUAL DISSOLVED S'OLID 8 CONCENTRATION, IN MILLIGRAMS PER LITER

- 250-- LINE OF EQUAL SULFATE CONCENTRATION, IN MILLIGRAMS PER LITER

- -250- LINE OF EQUAL CHLORIDE CONCENTRATION. IN MILLIORAMS PER LITER

WII AREA WHERE CONCENTRATIONS OF DISSOLVED 8 OLIDS, CHLORIDE, OR SULFATE ARE EQUAL TO OR OREATER THAN 500,250 , OR 250 MILLIORAMS PER LITER, RESPECTIVELY

Figure 38a.--Areas where water from the Suwannee-0cala (middle zone) Limestones exceed upper limits in concentrations of dissolved solids, chloride, and sulfate. 


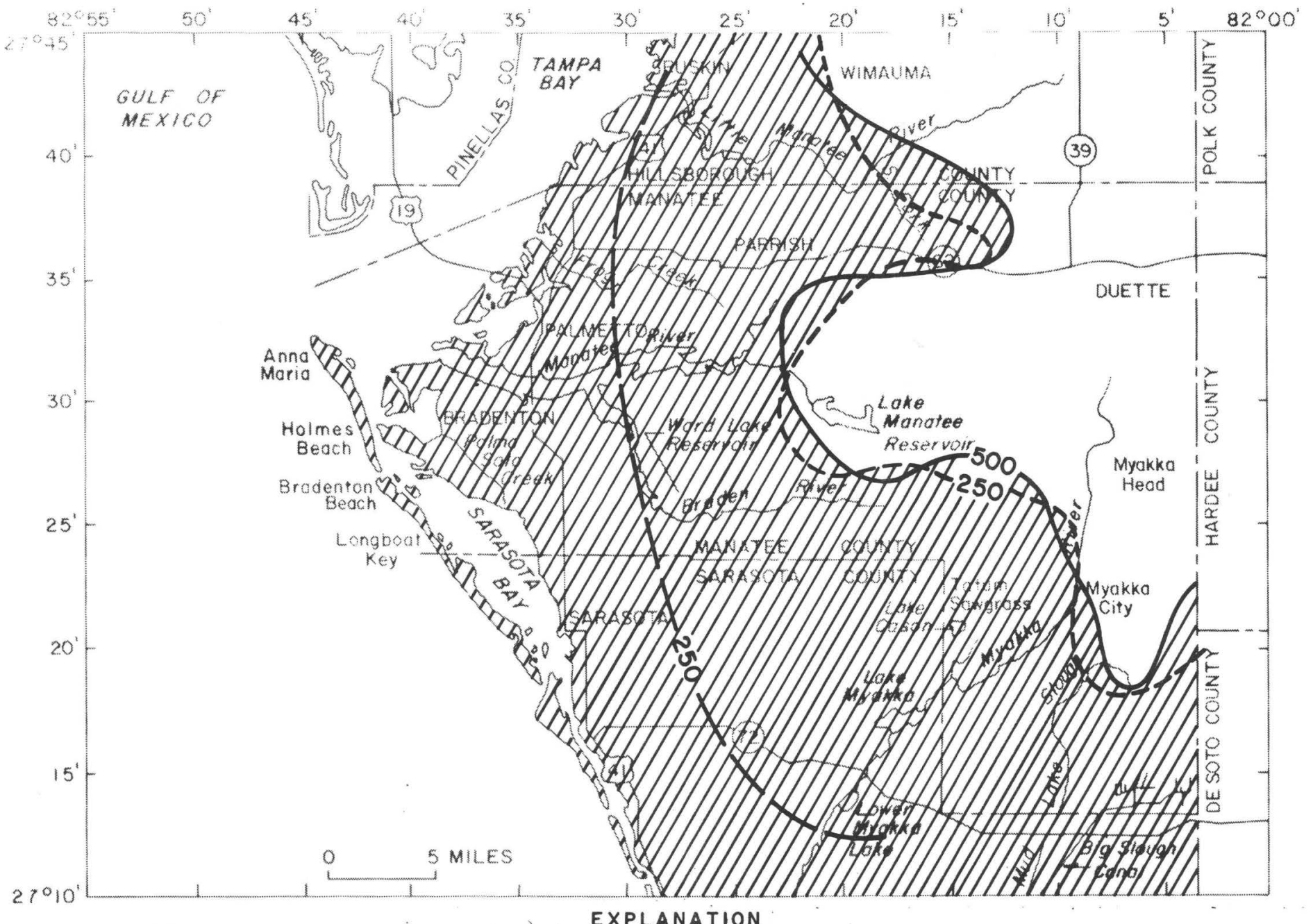

-500- LINE OF EQUAL DISSOLVED SOLIDS CONCENTRATION. IN MILLIGRAMS PER LITER

--250-- LINE OF EQUAL SULFATE CONCENTRATION. IN MILLIGRAMS PER LITER

- 250- - LINE OF EQUAL CHLORIDE CONCENTRATION, IN MILLIGRAMS PER LITER -

WDI AREA WHERE CONCENTRATIONS OF DISSOLVED SOLIDS. CHLORIDE, OR SULFATE ARE EQUAL TO OR GREATER THAN 500,250 , OR 250 MILLIGRAMS PER LITER, RESPECTIVELY

Figure 38b.--Areas where water from the Avon Park (lower zone) Limestone exceed upper limits in concentrations of dissolved solids, chloride, and sulfate. 
Table 18.--Water use, 1970-75

[ In million gallons per day]

\begin{tabular}{l|c|c|c|c|c|c|c}
\hline \multirow{2}{*}{ Year } & \multirow{2}{*}{$\begin{array}{c}\text { Population } \\
\text { served } \\
\text { (thousands) }\end{array}$} & \multicolumn{2}{|c|}{ Public supply } & \multicolumn{2}{c|}{$\begin{array}{c}\text { Industria1 } \\
\text { self-supplied }\end{array}$} & \multicolumn{2}{c}{$\begin{array}{c}\text { Thermoelectric } \\
\text { power }\end{array}$} \\
\cline { 3 - 8 } & $\begin{array}{c}\text { Ground } \\
\text { water }\end{array}$ & $\begin{array}{c}\text { Surface } \\
\text { water }\end{array}$ & $\begin{array}{c}\text { Ground } \\
\text { water }\end{array}$ & $\begin{array}{c}\text { Surface } \\
\text { water }\end{array}$ & $\begin{array}{c}\text { Ground } \\
\text { water }\end{array}$ & $\begin{array}{c}\text { Surface } \\
\text { water }\end{array}$ \\
\hline 1970 & 64.8 & 0.3 & 9.6 & 3.0 & - & - & - \\
1975 & 80.0 & 0 & $18.9^{\mathrm{a}}$ & 2.0 & - & - & $25.0^{\mathrm{b}}$ \\
\hline
\end{tabular}

\begin{tabular}{|c|c|c|c|c|c|c|c|c|}
\hline \multirow{3}{*}{ Year } & \multirow{3}{*}{ Acres } & \multirow{2}{*}{\multicolumn{2}{|c|}{ Irrigation }} & \multirow{3}{*}{$\begin{array}{l}\text { Population } \\
\text { served } \\
\text { (thousands) }\end{array}$} & \multicolumn{4}{|c|}{ County self-supplied } \\
\hline & & & & & \multicolumn{2}{|c|}{ Domestic } & \multicolumn{2}{|c|}{ Livestock } \\
\hline & & $\begin{array}{l}\text { Ground } \\
\text { water }\end{array}$ & $\begin{array}{c}\text { Surface } \\
\text { water }\end{array}$ & & $\begin{array}{l}\text { Ground } \\
\text { water }\end{array}$ & $\begin{array}{l}\text { Surface } \\
\text { water }\end{array}$ & $\begin{array}{l}\text { Ground } \\
\text { water }\end{array}$ & $\begin{array}{c}\text { Surface } \\
\text { water }\end{array}$ \\
\hline 1970 & 28,900 & 49.5 & - & ND & ND & ND & ND & ND \\
\hline 1975 & 25,750 & 22.8 & 1.2 & 43.5 & 4.4 & - & 1.6 & 0.2 \\
\hline
\end{tabular}

$\mathrm{a}_{\text {Includes }} 6 \mathrm{Mgal} / \mathrm{d}$ raw water supplied for industrial use.

Freshwater used to fill reservoir only, not in operation during 1975. ND-No data.

\section{Surface Water}

The Manatee County Utility System supplies water to Palmetto, Holmes Beach, Longboat Key, Anna Maria and Bradenton Beach, and the city of Bradenton. The county system in 1978 contracted to supply the Sarasota County Utility District No. 1 up to $10 \mathrm{Mgal} / \mathrm{d}$. In 1975, the average daily municipal pumpage was $9.9 \mathrm{Mgal} / \mathrm{d}$ serving an estimated 55,000 people (table 19). An additional 6.0 $\mathrm{Mgal} / \mathrm{d}$ was supplied for industrial use. By 1985, the average daily pumpage is estimated to be $27.4 \mathrm{Mgal} / \mathrm{d}$ (Texas Instruments Incorporated, 1978).

In 1975, the city of Bradenton supplied an average of $3.8 \mathrm{Mgal} / \mathrm{d}$ of water to a population of about 25,000. Of the total supply, about $3.1 \mathrm{Mgal} / \mathrm{d}$ was pumped from the Braden River (Ward Lake Reservoir) and $0.7 \mathrm{Mgal} / \mathrm{d}$ was purchased from the county system. During 1975, the water supply ranged from a monthly high of $4.26 \mathrm{Mgal} / \mathrm{d}$ in December to a monthly low of $3.31 \mathrm{Mgal} / \mathrm{d}$ in July. By 1985, the projected water demand for Bradenton will be $5.0 \mathrm{Mgal} / \mathrm{d}$.

Florida Power and Light's Manatee powerplant uses an estimated $14 \mathrm{Mgal} / \mathrm{d}$ of water from the Little Manatee River for its cooling system. By 1985, the projected water use for condenser cooling and for generating electric power will be $15 \mathrm{Mgal} / \mathrm{d}$. 
Table 19.--Water use for public supply, 1975 and 1977, and projected water use, 1980 and 1985

\begin{tabular}{|c|c|c|c|c|c|}
\hline \multirow{2}{*}{ Public supply } & \multirow{2}{*}{ Source } & \multicolumn{4}{|c|}{$\begin{array}{l}\text { Water use } \\
(\text { Mgal/d) }\end{array}$} \\
\hline & & $1975^{a}$ & $1977^{\mathrm{b}}$ & $1980^{\mathrm{b}}$ & $1985^{b}$ \\
\hline $\begin{array}{l}\text { Manatee County } \\
\text { Utility System }\end{array}$ & $\begin{array}{l}\text { Lake Manatee Reservoir } \\
\text { (Manatee River) }\end{array}$ & 9.9 & 19.1 & 22.2 & 27.4 \\
\hline City of Bradenton & $\begin{array}{l}\text { Ward's Lake (Braden } \\
\text { River) }\end{array}$ & 3.8 & 4.0 & 4.5 & 5.0 \\
\hline
\end{tabular}

Ground Water

The principal use of ground water is for agricultural irrigation, which averaged $49.5 \mathrm{Mgal} / \mathrm{d}$ in 1970 and $22.8 \mathrm{Mgal} / \mathrm{d}$ during 1975 (table 18). The decline in irrigation is probably due to more efficient methods of application. Irrigation is heaviest during the fall and winter-spring growing seasons.

\section{SUMMARY}

Manatee County, of the lower west coast of Florida, contains about $739 \mathrm{mi}^{2}$ of 1 and area and $46 \mathrm{mi}^{2}$ of inland water. The county lies within three physiographic units: the Gulf Coastal Lowlands, the DeSoto Plain, and the Polk Upland. Altitudes of land surface range from sea level along the coast to 130 feet above sea level in the northeast.

The major land uses are range, agricultural, urban, and mining. By the year 2000, projected major land uses are expected to remain rangeland and agricultural. Urban or built-up land is expected to increase about 30 percent. Projected land use in mining is expected to increase by 1985 and then decrease by 2000 , reflecting projected phosphate mining and reclamation in eastern Manatee County.

The source of freshwater is from rainfall in the county or adjacent areas. The average annual rainfall is about 55 inches. During the rainy season (June through September), rainfall ranges from about 6 to 9 inches per month. During the dry season (October through May), rainfall ranges from 1.5 to 3 inches per month. Evapotranspiration has been estimated to be about 39 inches per year.

Most streams have small drainage basins, short channel lengths, and do not yield high volumes of flow. Major streams draining Manatee County are the Myakka and Manatee Rivers. The Myakka River, near Sarasota, drains about $229 \mathrm{mi}^{2}$ in Manatee County and has a 41 -year average discharge, measured 36 miles upstream from its mouth, of $253 \mathrm{ft} / \mathrm{s}$ (15 inches of runoff per year). The river has a 
highly variable discharge that equals or exceeds $500 \mathrm{ft}^{3} / \mathrm{s} 50$ percent of the time. Discharge may cease for extended periods of time, or on the average, 14 consecutive days every 2 years and 90 days once in 10 years.

The Manatee River and its principal tributary, the Braden River, drain about $345 \mathrm{mi}^{2}$ in Manatee ${ }_{3}$ County. The 26-year average discharge at Manatee River near Bradenton is $109 \mathrm{ft} / \mathrm{s}$ (about 17 inches of runoff per year). Discharge equals or exceeds $24 \mathrm{ft}^{3} / \mathrm{s} 50$ percent of the time.

The surface water in Manatee County is generally less mineralized than ground water except in the tidally affected and coastal areas. The quality of surface water generally is suitable for most purposes. From June through September, streamflow is mainly a combination of ground-water discharge and direct runoff; concentrations of dissolved minerals and hardness are low and color is high. From October through May, streamflow is maintained by groundwater discharge; dissolved mineral concentrations and hardness increase and color decreases.

Water from the Manatee River (Lake Manatee Reservoir) and the Braden River (Ward Lake) is used for public supplies. Water from the Little Manatee River is used for a thermoelectric powerplant and cooling pond. At a pool elevation of 40 feet above sea leve1, Lake Manatee Reservoir has a surface area of 2.9 $\mathrm{mi}^{2}$ and a storage capacity of $7,000 \mathrm{Mgal}$. Draft-storage frequency relations indicate that at a 5 percent risk of having inadequate storage, the reservoir could supply a continuous draft of about $38 \mathrm{Mgal} / \mathrm{d}$. Ward Lake reservoir has a surface area of 57.6 acres and a storage capacity of about 585 Mgal. For a demand rate of $4.0 \mathrm{Mgal} / \mathrm{d}$ there is a 40 percent risk that the present storage will be inadequate. To provide a continuous draft of $50 \mathrm{Mgal} / \mathrm{d}$ at a 5 percent risk of failure, an estimated storage of about $11,000 \mathrm{Mgal}$ is required on the Myakka River near Sarasota, $11,000 \mathrm{Mgal}$ on the Manatee River near Myakka Head, and $8,400 \mathrm{Mgal}$ on the Little Manatee River near Wimauma.

Ground water occurs under unconfined and confined conditions. Unconfined conditions occur in the surficial aquifer, which consists of deposits of sand, grave1, shel1, and limestone. Confined ground water occurs in permeable zones within the carbonate strata of the Floridan aquifer.

The upper confining bed that separates the surficial and Floridan aquifers consists of sandy clays, clays, and marls. Within the upper confining bed there are permeable sand, gravel, shell, and limestone beds that form the minor artesian aquifer.

The Floridan aquifer consists of at least three permeable zones of limestone and dolomite that generally function as a single hydrologic unit. The principal water-bearing zones are: (1) the uppermost limestone (in part, the Tampa Limestone and, in part, the Hawthorn Formation); (2) the lower part of the Suwannee Limestone--upper part of the Ocala Limestone; and (3) the Avon Park Limestone below the top 100 feet (dolomite unit).

The lower confining bed of the Floridan aquifer consists of limestone and dolomite of the Lake City Limestone. The upper part of the Lake City Limestone contains highly mineralized water and is nearly impermeable. 
The quality of ground water is generally good except in the western and southern parts of the county where saltwater intrusion or incomplete flushing of residual seawater has occurred. The quality of water in the surficial and minor artesian aquifers is of acceptable quality except near the coast and tidal-affected streams. The water in the Floridan aquifer is generally more mineralized than water from the surficial and minor artesian aquifers.

The mineral content of the water from the Floridan aquifer generally increases with depth and from the northeastern part of the county towards the west and south. Concentrations of dissolved solids range from about $300 \mathrm{mg} / \mathrm{L}$ in the northeastern part of the county to $2,500 \mathrm{mg} / \mathrm{L}$ in the western part. Concentrations of chloride are less than $250 \mathrm{mg} / \mathrm{L}$ except near the coast where saltwater intrusion has occurred. In eastern Manatee County, concentrations of chloride are generally less than $50 \mathrm{mg} / \mathrm{L}$. Concentrations of sulfate range from about 5 to $900 \mathrm{mg} / \mathrm{L}$, generally increasing with depth and from the northeastern part of the county towards the west and south. Relatively high concentrations of sulfate (more than $250 \mathrm{mg} / \mathrm{L}$ ) occur in the western and southern parts of the county.

Ground water is used primarily for agricultural irrigation. An average of 22.8 Mgal/d was used during the $1975 \mathrm{fall}$ and 1975-76 winter-spring growing seasons. The minor artesian aquifer is a major source of water for rural domestic supply. The surficial aquifer is generally undeveloped as a source of water.

\section{SELECTED REFERENCES}

Buono, Anthony, and Rutledge, A. T., 1978, Configuration of the top of the Floridan aquifer, Southwest Florida Water Management District and adjacent areas: U.S. Geological Survey Water-Resources Investigations OpenFile Report 78-34.

Cathcart, J. B., and McGreevy, L. J., 1959, Results of geologic exploration by core drilling, 1953 land-pebble phosphate district, Florida: U.S. Geological Survey Bulletin 1046-K, p. 221-298.

Cherry, R. N., Stewart, J. W., and Mann, J. A., 1970, General hydrology of the middle Gulf area, Florida: Florida Geological Survey Report of Investigations 56, $96 \mathrm{p}$.

Cooper, H. C., Kohout, F. A., Henry, H. R., and Glover, R. E., 1964, Sea water in coastal aquifers, U.S. Geological Survey Water-Supply Paper 1613-C, $84 \mathrm{p}$.

Conover, C. S., and Leach, S. D., 1975, Drainage basins in Florida: Florida Bureau of Geology Map Series 72.

Duerr, A. D., 1974, Hydrologic data from wells in southwest Hillsborough County, Florida, 1950-74: U.S. Geological Survey open-file report FL-74031, 53 p.

1975a, The potentiometric surface and water quality of the Floridan aquifer in southwest. Hillsborough County, Florida, 1952-74: U.S. Geological Survey Water-Resources Investigations 50-75.

Ferguson, G. E., Lingham, C. W., Love, S. K., and Vernon, R. 0., 1947, Springs of Florida: Florida Geological Survey Bulletin 31, 198 p. 
Flippo, H. N., Jr., and Joyner, B. F., 1968, Low streamflow in the Myakka River basin area in Florida: Florida Geological Survey Report of Investigations $53,34 \mathrm{p}$.

Florida Board of Conservation, 1969, Florida Gazatteer, Part 3: State of Florida Publication, 145 p.

Geraghty and Miller, Inc., 1978, Hydrologic effects of developing 15 MGD of the water from the Floridan aquifer in the Pine Level area, DeSoto and Manatee Counties, Florida: Consultants' report for Phillips Petroleum Company in files of the Southwest Florida Water Management District.

Hammett, K. M., Turner, J. F., Jr., and Murphy, W. R., Jr., 1978, Magnitude and frequency of flooding on the Myakka River, southwest Florida: U.S. Geologica1 Survey Water-Resources Investigations 78-65, 40 p.

Healy, H. G., 1962, Piezometric surface of the Floridan aquifer in Florida, July 6-17, 1961: Florida Division of Geology Map Series 1.

1977, Public water supplies of selected municipalities in Florida, 1975: U.S. Geological Survey Water-Resources Investigations 77-53, 309 p.

Hem, J. D., 1970, Study and interpretation of the chemical characteristics of natural water: U.S. Geological Survey Water-Supply Paper 1473, 269 p.

Hughes, G. H., Hampton, E. R., and Tucker, D. F., 1971, Annual and seasonal rainfall in Florida: Florida Bureau of Geology Map Series 40.

Hutchinson, C. B., 1977, Appraisal of shallow ground-water resources and management alternatives in the upper Peace and eastern Alafia River basins, Florida: U.S. Geological Survey Water-Resources Investigations 77-124, $57 \mathrm{p}$.

Hutchinson, C. B., and Wilson, W. E., 1974, Evaluation of a proposed connector we11, northeastern DeSoto County, Florida: U.S. Geological Survey WaterResources Investigations 5-74, $41 \mathrm{p}$.

Irwin, G. A., and Hutchinson, C. B., 1976, Radium-226 reconnaissance water sampling of eight Florida counties, December 1974-January 1975: U.S. Geological Survey Water-Resources Investigations 76-103, 16 p.

Joyner, B. F., and Sutcliffe, H., Jr., 1976, Water resources of Myakka River basin area, Florida: U.S. Geological Survey Water-Resources Investigations $76-58,87 \mathrm{p}$.

Kaufman, M. I., 1969 (revised 1975), Color of water in Florida streams and canals: Florida Bureau of Geology Map Series 35.

1972 (revised 1975), The chemical type of water in Florida streams: Florida Bureau of Geology Map Series 51.

Kaufman, M. I., and Dion, N. P., 1967, Chemical character of water in the Floridan aquifer in southern Peace River basin, Florida, 1967: Florida Geological Survey Map Series 27.

1968, Ground-water resources data, Charlotte, DeSoto, and Hardee Counties, Florida: Florida Geological Survey Information Circular $53,24 \mathrm{p}$.

Kenner, W. E., 1969 (revised 1975), Seasonal variations of streamflow in Florida, 1969: Florida Geological Survey Map Series 31. 
Kenner, W. E., Hampton, E. R., and Conover, C. S., 1969 (revised 1975), Average flow of major streams in Florida: Florida Bureau of Geology Map Series 34.

Klein, Howard, 1971 (revised 1975), Depth to base of potable water in the Floridan aquifer: Florida Bureau of Geology Map Series 42.

Leach, S. D., 1977, Water-use inventory in Florida, 1975: U.S. Geological Survey Open-File Report 77-577, 90 p.

Lohman, S. W., 1972, Ground-water hydraulics: U.S. Geological Survey Professional Paper $708,70 \mathrm{p}$.

Lohman and others, 1972, Definitions of selected ground-water terms--revisions and conceptual refinements: U.S. Geologica1 Survey Water-Supply Paper $1988,21 \mathrm{p}$.

Menke, G. G., Meredith, E. W., and Wetterha11, W. S., 1961, Water resources of Hillsborough County, Florida: Florida Geological Survey Report of Investigations 25, $101 \mathrm{p}$.

Mills, L. R., and Laughlin, C. P., 1976, Potentiometric surface of the Floridan aquifer, May 1975, and change of the potentiometric surface, 1969 to 1975, Southwest Florida Water Management District and adjacent areas: U.S. Geological Survey Water-Resources Investigations 76-80.

Mills, L. R., Laughlin, C. P., and Parsons, D. C., 1976, Potentiometric surface of the Floridan aquifer, Southwest Florida Water Management District, September 1975: U.S. Geological Survey open-file report FL-76003.

National Academy of Sciences and National Academy of Engineering, 1973, Water quality criteria, 1972: U.S. Environmental Protection Agency Report EPA R3 73 033, 594 p.

P. E. LaMoreaux and Associates, Inc., May 1974, Analysis of the surface water conditions of the Beker Property, Manatee County, Florida: Consultants' report prepared for Beker Industries Corporation, Natural Resources Division, Tampa, Florida, in files of the Southwest Florida Water Management District.

Parker, G. G., Ferguson, G. E., Love, S. K., and others, 1955, Water resources of southeastern Florida, with special reference to the geology and ground water of the Miami area: U.S. Geological Survey Water-Supply Paper 1255, $965 \mathrm{p}$.

Pascale, C. A., 1975, Estimated yield of fresh-water wells in Florida: Florida Bureau of Geology Map Series 70.

Peek, H. M., 1958a, Ground-water resources of Manatee County, Florida: Florida Geological Survey Report of Investigations 18, 99 p.

1958b, Record of wells in Manatee County, Florida: Florida Geological Survey Information Circular 19, 196 p.

1959a, Record of wells in the Ruskin area, Hillsborough County, Florida: Florida Geological Survey Information Circular 22, 85 p.

1959b, The artesian water of the Ruskin area of Hillsborough County, Florida: Florida Geological Survey Report of Investigations 21, 96 p.

Peek, H. M., and Anders, R. B., 1955, Interim report on the ground-water resources of Manatee County, Florida: Florida Geological Survey Information Circular 6, $38 \mathrm{p}$. 
Pride, R. W., [1975], Estimated water use in Florida, 1965 (2d ed.) : Florida Bureau of Geology Map Series 36.

1973, Estimated water use in Florida, 1970: Florida Bureau of Geology Information Circular 83, $31 \mathrm{p}$.

Pride, R. W., Meyer, F. W., and Cherry, R. N., 1966, Hydrology of Green Swamp area in central Florida: Florida Bureau of Geology Report of Investigations 42, $137 \mathrm{p}$.

Rosenau, J. C., Faulkner, G. L., Hendry, C. W., Jr., and Hul1, R. W., 1977 (revised), Springs of Florida: Florida Bureau of Geology Bulletin 31, $198 \mathrm{p}$.

Ryder, P. D., Laughlin, C. P., and Mills, L. R., 1976, Potentiometric surface of the Floridan aquifer, Southwest Florida Water Management District, September 1976: U.S. Geological Survey Open-File Report 77-353.

Hutchinson, C. B., and Mills, L. R., 1977, Water table in the surficial aquifer and potentiometric surface of the Floridan aquifer in selected well fields, west-central Florida, May 1976: U.S. Geological Survey Open-File Report $77-257,14 \mathrm{p}$. and 4 sheets.

Ryder, P. D., and Mills, L. R., 1977, Water table in the surficial aquifer and potentiometric surface of the Floridan aquifer in selected well fields, west-central Florida, September 1976: U.S. Geological Survey Open-File Report 77-551, 13 p. and 4 sheets.

Sinclair, W. C., 1974, Hydrogeologic characteristics of the surficial aquifer in northwest Hillsborough County, Florida: Florida Bureau of Geology Information Circular 86, 98 p.

1977, Experimental study of artificial recharge alternatives in northwest Hillsborough County, Florida: U.S. Geological Survey Water-Resources Investigations $77-13,52 \mathrm{p}$.

Smalley, Wellford and Nalvin, 1977, Manasota literature assessment study: Consultants' report for Board of Sarasota County Commissioners, 130 p.

Smith and Gillespie Engineers, Inc., 1971, Engineer's preliminary report on Braden River supply for City of Bradenton, Florida: Consultants' report prepared for City of Bradenton, Florida, in files of Southwest Florida Water Management District.

Southwest Florida Water Management District, 1978, Water use plan, 78: Southwest Florida Water Management District, Brooksville, Florida, 65 p.

Stewart, H. G., Jr., 1966, Ground-water resources of Polk County: Florida Geological Survey Report of Investigations 44, 170 p.

Stewart, J. W., and Laughlin, C. P., 1976, Potentiometric surface of the Floridan aquifer, Southwest Florida Water Management District, May 1976: U.S. Geological Survey open-file report FL-76005.

Stewart, J. W., Mills, L. R., Knochenmus, D. D., and Faulkner, G. L., 1971, Potentiometric surface and areas of artesian flow, May 1969, and change of potentiometric surface 1964 to 1969, Floridan aquifer, Southwest Florida Water Management District, Florida: U.S. Geological Survey Hydrologic Investigation Atlas HA-440.

Stringfield, V. T., 1936, Artesian water in the Florida peninsula: U.S. Geological Survey Water-Supply Paper 773-C, p. 115-195.

1966, Artesian water in Tertiary limestone in the southeastern states: U.S. Geological Survey Professional Paper 517, 226 p. 
Sutcliffe, H., Jr., 1975, Appraisal of the water resources of Charlotte County, Florida: Florida Bureau of Geology Report of Investigations 78, 53 p.

1979, Hydrologic records, Verna well-field area, City of Sarasota, Florida, 1962-76--a data report: U.S. Geologica1 Survey Open-File Report 79-1259, 141 p.

Sutcliffe, H., Jr., and Joyner, B. F., 1968, Test well exploration in the Myakka River basin area, Florida: Florida Geological Survey Information Circular 56, 61 p.

Texas Instruments Incorporated, 1978, Water: U.S. Environmental Protection Agency, Central Florida Phosphate Industry Areawide Impact Assessment Program, v. 5, 309 p.

Toler, L. G., 1967, Fluoride in water in the Alafia and Peace River basins, Florida: Florida Geological Survey Report of Investigations 46,46 p.

U.S. Environmental Protection Agency, 1978, Draft areawide environmental impact statement, central Florida phosphate industry, $179 \mathrm{p}$.

U.S. Geological Survey, Surface water records of Florida, Volume 1, Streams: 1961, 1962, 1963, 1964.

Surface water records of Florida, Volume 2, Lakes: 1961, 1962, 1963, 1964.

Water resources data for Florida, Part 1, Surface water records, Volume 1, Streams: 1965.

Water resources data for Florida, Part 1, Surface water records, Volume 2, Lakes: 1965.

Water resources data for Florida, Part 1, Surface water records, Volume 1, Streams--northern and central Florida: 1966, 1967, 1968, 1969, 1970, 1971, 1972, 1973, 1974.

Water resources data for Florida, Part 1, Surface water records, Volume 2, Streams--southern Florida, Lake Okeechobee and the Everglades: 1966, $1967,1968,1969,1970,1971,1972$.

Water resources data for Florida, Part 1, Surface water records, Volume 3, Lakes: 1966, 1967, 1968, 1969, 1970, 1971, 1972, 1973, 1974.

Water resources data for Florida, Part 2, Water quality records: 1965, 1966, 1967, 1968, 1969, 1970, 1971, 1972, 1973, 1974.

Water resources data for Florida, Volume 3, west-central Florida, surface water, ground water, quality of water: 1975.

Water resources data for Florida, Volume 3, southwest Florida, surface water, ground water, quality of water: 1976, 1977.

Vernon, R. O., and Puri, H. S., 1965, Geologic map of Florida: Florida Geological Survey Map Series 18.

Visher, F. N., and Hughes, G. H., 1969 (revised 1975), The difference in rainfall and potential evaporation in Florida: Florida Bureau of Geology Map Series 32.

Walton, W. C., 1970, Groundwater resource evaluation: New York, McGraw-Hi11, $664 \mathrm{p}$. 
White, W. A., 1970, The geomorphology of the Florida peninsula: Florida Bureau of Geology Bulletin 51, 164 p.

William F. Guyton and Associates, 1976a, Test hole geology: Consultants' report prepared for Swift Agricultural Chemicals Corporation, Manatee mine site in files of Southwest Florida Water Management District.

1976b, Well inventory, irrigation well logging and well construction: Consultants' report prepared for Swift Agricultural Chemicals Corporation, Manatee mine site, in files of Southwest Florida Water Management District.

$1976 \mathrm{c}$, Test hole geophysics and bore hole flow: Cosultants' report prepared for Swift Agricultural Chemicals Corporation, Manatee mine site in files of Southwest Florida Water Management District.

1976d, Hydraulics and water quality: Consultants' report prepared for Swift Agricultural Chemicals Corporation, Manatee mine site in files of Southwest Florida Water Management District.

Wilson, W. E., 1972, Hydrogeology of Florida's largest citrus grove: American Society of Civil Engineers, Irrigation and Drainage Division Speciality Conference proceedings, p. 293-307.

1977a, Ground-water resources of DeSoto and Hardee Counties, Florida: Florida Bureau of Geology Report of Investigations 83, 102 p.

$1977 b$, Simulated changes in ground-water levels resulting from proposed phosphate mining, west-central Florida--preliminary results: U.S. Geological Survey Open-File Report 77-882, 46 p.

Wilson, W. E., and Gerhart, J. M., 1979, Simulated effects of ground-water development on potentiometric surface of the Floridan aquifer, west-central Florida: U.S. Geological Survey Water-Resources Investigations 79-1271, $173 \mathrm{p}$.

Wolansky, R. M., 1978, Feasibility of water-supply development from the unconfined aquifer in Charlotte County, Florida: U.S. Geological Survey WaterResources Investigations 78-26, $34 \mathrm{p}$. 